\title{
Environmental
}

Assessment

A 1526997

OSTI

\section{LEAD TEST ASSEMBLY IRRADIATION AND ANALYSIS WATTS BAR NUCLEAR PLANT, TENNESSEE AND HANFORD SITE, MHOTER RICHLAND, WASHINGTON}

\author{
U. S. DEPARTMENT OF ENERGY \\ RICHLAND OPERATIONS OFFICE \\ COOPERATING AGENCY: \\ TENNESSEE VALLEY AUTHORITY
}

DISTRIBUTION OF THIS DOCUMENT IS UNLIMTTED July 1997 



\section{DISCLAMMER}

Portions of this document may be illegible in electronic image products. Images are produced from the best available original document. 



\section{Environmental}

Assessment

\section{LEAD TEST ASSEMBLY \\ IRRADIATION AND ANALYSIS \\ WATTS BAR NUCLEAR PLANT, \\ TENNESSEE AND \\ HANFORD SITE, \\ RICHLAND, WASHINGTON}

U. S. DEPARTMENT OF ENERGY

RICHLAND OPERATIONS OFFICE

COOPERATING AGENCY:

TENNESSEE VALLEY AUTHORITY

July 1997 


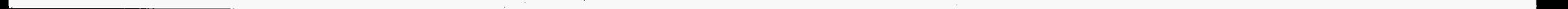




\section{Acronyms and Abbreviations}

$\begin{array}{ll}\text { ALARA } & \text { as low as reasonably achievable } \\ \text { ANL-W } & \text { Argonne National Laboratory-West } \\ \text { BWR } & \text { boiling water reactor } \\ \text { CFR } & \text { Code of Federal Regulations } \\ \text { CEDE } & \text { committed effective dose equivalent } \\ \text { CEQ } & \text { Council on Environmental Quality } \\ \text { Ci } & \text { Curie (unit of radioactivity) } \\ \text { CLWR } & \text { Commercial Light Water Reactor } \\ \text { DOE } & \text { U.S. Department of Energy } \\ \text { DOT } & \text { U.S. Department of Transportation } \\ \text { EA } & \text { environmental assessment } \\ \text { EDE } & \text { effective dose equivalent } \\ \text { EFPD } & \text { effective full power days } \\ \text { EIS } & \text { Environmental Impact Statement } \\ \text { FFTF } & \text { Fast Flux Test Facility } \\ \text { FONSI } & \text { Finding of No Significant Impact } \\ \text { FR } & \text { Federal Register } \\ \text { FSAR } & \text { Final Safety Analysis Report } \\ \text { HCRL } & \text { Hanford Cultural Resources Laboratory } \\ \text { HFEF } & \text { Hot Fuels Examination Facility } \\ \text { ICRP } & \text { International Commission on Radiological Protection } \\ \text { INEEL } & \text { Idaho National Engineering and Environmental Laboratory } \\ \text { kW } & \text { kilowatt } \\ \text { LCF } & \text { latent cancer fatality } \\ \text { LTA } & \text { lead test assembly } \\ \text { LWR } & \text { light water reactor } \\ \text { MEI } & \text { maximally exposed individual } \\ \text { MTF } & \text { Memorandum-to-File } \\ \text { MWe } & \text { megawatt (electric) } \\ \text { NDE } & \text { nondestructive examination } \\ \text { NEPA } & \text { National Environmental Policy Act of 1969 } \\ \text { NRC } & \text { U.S. Nuclear Regulatory Commission } \\ \text { NTS } & \text { Nevada Test Site } \\ \text { ORR } & \text { Oak Ridge Reservation } \\ \text { PIE } & \text { post-irradiation examination } \\ \text { PWR } & \text { pressurized water reactor } \\ \text { R\&D } & \text { research and development } \\ \text { RCRA } & \text { Resource Conservation and Recovery Act of 1976 } \\ \text { rem } & \text { radiation equivalent man (unit of radiation dose equivalent) } \\ \text { Sv } & \text { Sievert (unit of radiation dose equivalent) } \\ \text { TPBAR } & \text { tritium-producing burnable absorber rod } \\ \text { TSR PEIS } & \text { (DOE) Programmatic EIS for Tritium Supply and Recycling } \\ \text { WDA } & \text { Tennessee Valley Authority } \\ \text { Washington Administrative Code } \\ \text { Watts Bar Nuclear Plant } \\ \text { State of Washington Department of Fish and Wildlife } \\ \end{array}$




\section{Metric Conversion Chart}

\begin{tabular}{|c|c|c|}
\hline If you know & Multiply by & To get \\
\hline \multicolumn{3}{|c|}{ Length } \\
\hline centimeters & 0.394 & inches \\
\hline meters & 3.281 & feet \\
\hline square meters & 10.764 & square feet \\
\hline kilometers & 0.621 & miles \\
\hline \multicolumn{3}{|c|}{ Area } \\
\hline hectares & 2.471 & acres \\
\hline square kilometers & 0.386 & square miles \\
\hline \multicolumn{3}{|c|}{ Mass (weight) } \\
\hline kilograms & 2.205 & pounds \\
\hline \multicolumn{3}{|c|}{ Volume } \\
\hline liters & 0.264 & gallons \\
\hline cubic meters & 35.315 & cubic feet \\
\hline \multicolumn{3}{|c|}{ Radiological Units } \\
\hline $\begin{array}{l}\text { disintegrations per } \\
\text { second }\end{array}$ & $2.7 \times 10^{-11}$ & Curies \\
\hline Sieverts & 100 & rem \\
\hline
\end{tabular}

From the CRC Handbook of Chemistry and Physics, Robert C. Weast, Ph.D., 70th Ed., 1989-1990, CRC Press, Inc., Boca Raton, Florida.

And

Eckerman, K. F., A. B. Wolbarst, and A. C. B. Richardson. 1988. Limiting Values of Radionuclide Intake and Air Concentration and Dose Conversion Factors for Inhalation, Submersion, and Ingestion. Federal Guidance Report No. 11, EPA/520/1-88-020, Office of Radiation Programs, U.S. Environmental Protection Agency, Washington, D.C. 


\section{Numerical (Scientific or Exponential) Notation}

Numbers that are very small or very large are often expressed in scientific or exponential notation as a matter of convenience. For example, the number 0.000034 may be expressed as $3.4 \times 10^{-5}$ or $3.4 \mathrm{E}-05$ and 65,000 may be expressed as $6.5 \times 10^{4}$ or $6.5 \mathrm{E}+04$. Multiples or sub-multiples of the basic units are also used. A partial list of multiples and sub-multiples follows:

\begin{tabular}{|c|c|c|c|c|}
\hline Name & Symbol & & Value Mult & iplied by: \\
\hline atto & $\bar{a}$ & 0.000000000000000001 & or $1 \times 10^{-18}$ & or $1 \mathrm{E}-18$ \\
\hline femto & $\mathrm{f}$ & 0.000000000000001 & or $1 \times 10^{-15}$ & or $1 \mathrm{E}-15$ \\
\hline pico & $\mathrm{p}$ & 0.000000000001 & or $1 \times 10^{-12}$ & or $1 \mathrm{E}-12$ \\
\hline nano & $\mathbf{n}$ & 0.000000001 & or $1 \times 10^{-9}$ & or 1E-09 \\
\hline micro & $\mu$ & 0.000001 & or $1 \times 10^{-6}$ & or $1 \mathrm{E}-06$ \\
\hline milli & m & 0.001 & or $1 \times 10^{-3}$ & or $1 \mathrm{E}-03$ \\
\hline kilo & k & 1,000 & or $1 \times 10^{3}$ & or $1 \mathrm{E}+03$ \\
\hline mega & $\mathbf{M}$ & $1,000,000$ & or $1 \times 10^{6}$ & or $1 \mathrm{E}+06$ \\
\hline giga & G & $1,000,000,000$ & or $1 \times 10^{9}$ & or $1 \mathrm{E}+09$ \\
\hline tera & $\mathrm{T}$ & $1,000,000,000,000$ & or $1 \times 10^{12}$ & or $1 E+12$ \\
\hline
\end{tabular}

The following symbols are occasionally used in conjunction with numerical expressions:

$<$ less than

$\leq$ less than or equal to

$>$ greater than

$\geq$ greater than or equal to

In this environmental assessment, numerical values that are less than 0.001 or greater than 9999 are generally expressed in exponential notation. 


\section{Preface}

This environmental assessment (EA) has been prepared to assess potential environmental impacts associated with a U.S. Department of Energy (DOE) Proposed Action to conduct a lead test assembly (LTA) program to confirm the viability of using a commercial light water reactor (CLWR) to produce tritium. The Proposed Action described in this EA supports DOE's Record of Decision for the Programmatic Environmental Impact Statement for Tritium Supply and Recycling (TSR PEIS). This EA tiers from the TSR PEIS and covers only those activities necessary to conduct tests involving irradiation of tritium-producing burnable absorber rods (TPBARs) in a CLWR and post-irradiation examination (PIE) of the TPBARs. The Proposed Action would involve preparation and analysis activities at DOE facilities and irradiation of the TPBARs at a commercial nuclear power reactor. This confirmatory test draws on over 10 years of DOE research and development devoted to the safe and efficient production of tritium in CLWRs.

If the Proposed Action is found to be a major federal action that significantly affects the quality of the human environment, an environmental impact statement will be prepared. If the Proposed Action is not found to constitute a major federal action that significantly affects the quality of the environment, a Finding of No Significant Impact (FONSI) will be issued and the action will proceed. Criteria used to evaluate the significance can be found in the Code of Federal Regulations (CFR) at 40 CFR 1508.27.

This EA was prepared in compliance with the National Environmental Policy Act (NEPA) of 1969 (as amended), the Council on Environmental Quality (CEQ) regulations for Implementing the Procedural Provisions of NEPA (40 CFR 1500-1508), and the U.S. Department of Energy NEPA regulations (10 CFR 1021). The Tennessee Valley Authority (TVA) is participating with the DOE as a cooperating agency in the preparation of this EA, in accordance with its established procedures for implementing NEPA requirements. The following is a description of each section of this environmental assessment:

1.0 Purpose and Need for Agency Action provides a brief statement and background information concerning the issue the DOE is addressing with the Proposed Action.

2.0 Proposed Action contains a description of the Proposed Action.

3.0 Alternatives to the Proposed Action contains a description of alternative actions that meet DOE's defined purpose and need, as well as a description of a no-action alternative.

4.0 Affected Environment provides a brief description of the sites and associated environment in which the Proposed Action would occur.

5.0 Environmental Impacts identifies and describes the range of environmental impacts, beneficial and adverse, that might occur if the Proposed Action were implemented. Impacts of alternatives are also briefly discussed.

6.0 Permits and Regulatory Requirements identifies and describes regulatory requirements and permits that are applicable to the Proposed Action.

7.0 Agencies and Organizations Consulted identifies outside parties that were or will be contacted as part of the process of preparing the environmental documentation . 


\section{Table of Contents}

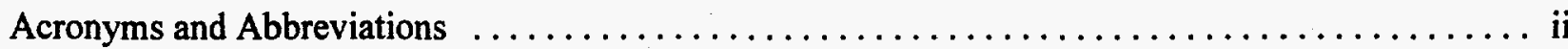

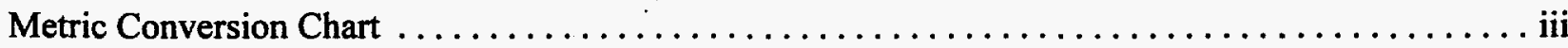

Numerical (Scientific or Exponential) Notation $\ldots \ldots \ldots \ldots \ldots \ldots \ldots \ldots \ldots \ldots$ iv

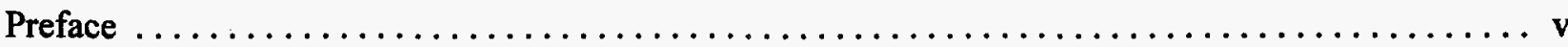

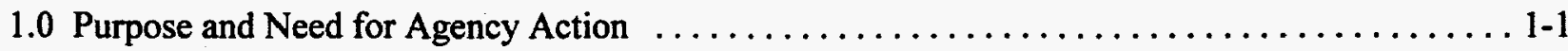

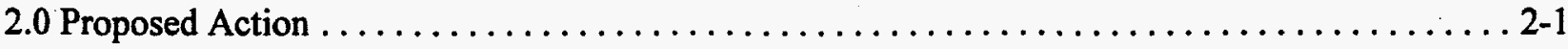

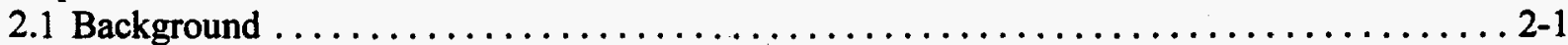

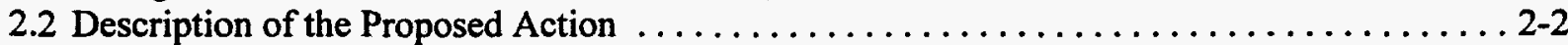

2.2.1 Pre-Irradiation Transport and Assembly of TPBAR-LTAs $\ldots \ldots \ldots \ldots \ldots \ldots \ldots \ldots .2-3$

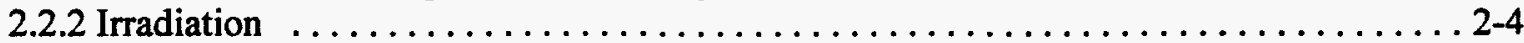

2.2.3 Post-Irradiation Transportation $\ldots \ldots \ldots \ldots \ldots \ldots \ldots \ldots \ldots \ldots \ldots \ldots \ldots \ldots \ldots \ldots, 4$

2.2.4 Post-Irradiation Examination $\ldots \ldots \ldots \ldots \ldots \ldots \ldots \ldots \ldots \ldots \ldots \ldots, \ldots \ldots \ldots, 2-4$

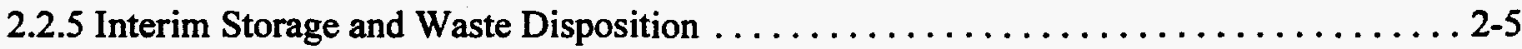

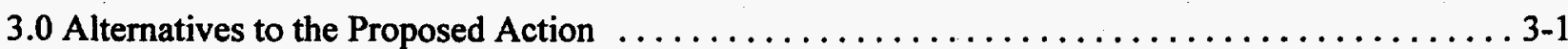

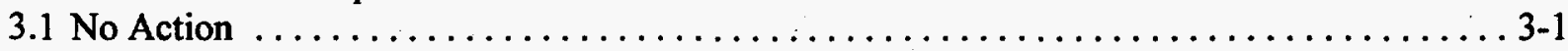

3.2 Irradiation at Other Reactor/Analysis at Other DOE Laboratory $\ldots \ldots \ldots \ldots \ldots \ldots \ldots .1$

3.3 Examination at a Private Facility $\ldots \ldots \ldots \ldots \ldots \ldots \ldots \ldots \ldots \ldots \ldots \ldots \ldots \ldots \ldots \ldots .1$

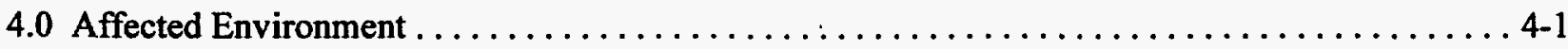

4.1 Hanford Site Description $\ldots \ldots \ldots \ldots \ldots \ldots \ldots \ldots \ldots \ldots \ldots \ldots \ldots \ldots \ldots \ldots, 1$

4.2 The 300 Area of the Hanford Site $\ldots \ldots \ldots \ldots \ldots \ldots \ldots \ldots \ldots \ldots \ldots \ldots \ldots \ldots \ldots, 2$

4.3 Watts Bar Nuclear Plant $\ldots \ldots \ldots \ldots \ldots \ldots \ldots \ldots \ldots \ldots \ldots \ldots \ldots \ldots \ldots \ldots \ldots, 2$

4.4 Argonne National Laboratory-West $\ldots \ldots \ldots \ldots \ldots \ldots \ldots \ldots \ldots \ldots \ldots \ldots \ldots \ldots \ldots, 4$

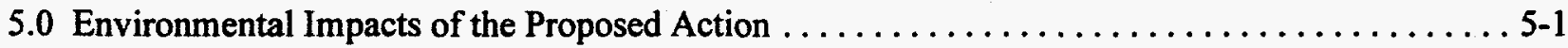

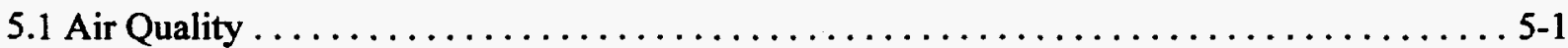

5.1.1 Atmospheric Emissions of Radionuclides ......................

5.1.1.1 Assembly and Incorporation of the TPBAR-LTAs into the Integrated Assemblies 5-1

5.1.1.2 Irradiation of TPBAR-LTAs, Transportation, and NDE $\ldots \ldots \ldots \ldots \ldots \ldots \ldots .5$. 1

5.1.1.3 Post-Irradiation Examination of TPBARs $\ldots \ldots \ldots \ldots \ldots \ldots \ldots \ldots \ldots \ldots .5,2$

5.1.2 Atmospheric Emissions of Regulated Nonradioactive Materials ............. 5-3

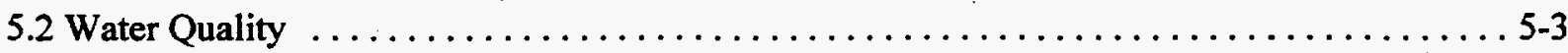

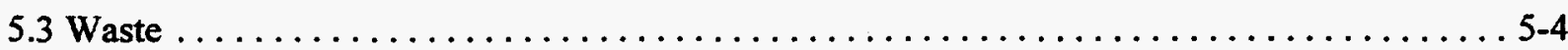

5.3.1 Assembly and Incorporation of TPBAR-LTAs into the Integrated Assemblies . . . . . 5 5-4

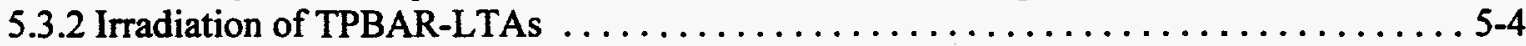

5.3.3 Post-Irradiation Examination of TPBARs . . . . . . . . . . . . . . . . . . . . .

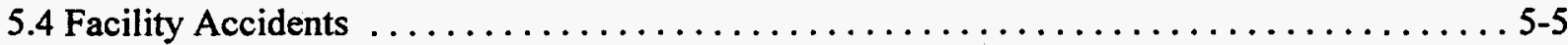

5.4.1 Assembly and Incorporation of TPBAR-LTAs into the Integrated Assemblies ..... 5-5

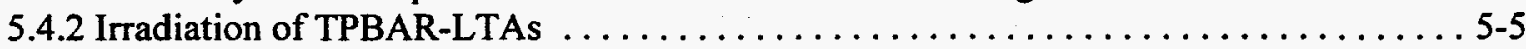


5.4.3 Post-Irradiation Examination of TPBARs $\ldots \ldots \ldots \ldots \ldots \ldots \ldots \ldots \ldots \ldots \ldots \ldots$

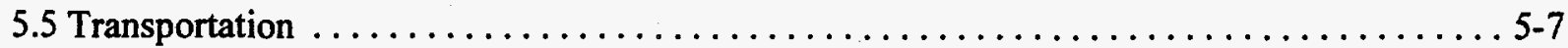

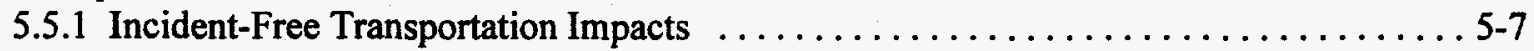

5.5.1.1 Potential Radiological Impacts $\ldots \ldots \ldots \ldots \ldots \ldots \ldots \ldots \ldots \ldots \ldots \ldots \ldots$

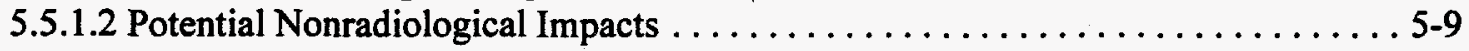

5.5.2 Transportation Accident Impacts . . . . . . . . . . . . . . . . . . . 5-9

5.5.2.1 Radiological Impacts to the Public from Transportation Accidents . . . . . . . . 5-9

5.5.2.2 Nonradiological Impacts to the Public from Transportation Accidents . . . . . 5-10

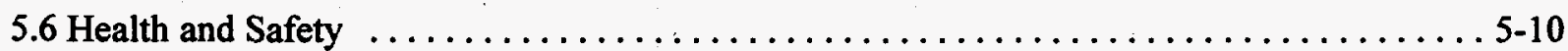

5.6.1 Basis for Health and Safety Consequences $\ldots \ldots \ldots \ldots \ldots \ldots \ldots \ldots \ldots \ldots \ldots \ldots$ 5-10

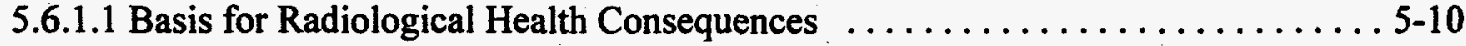

5.6.1.2 Basis for Nonradiological Health Consequences $\ldots \ldots \ldots \ldots \ldots \ldots \ldots \ldots \ldots .11$

5.6.2 Worker Health and Safety Consequences of the Proposed Action . . . . . . . . . 5-12

5.6.3 Public Health and Safety Consequences of the Proposed Action . . . . . . . . . 5-13

5.6.4 Summary of Health and Safety Consequences of the Proposed Action . . . . . . . 5-14

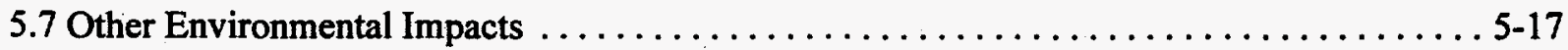

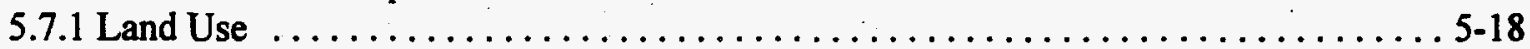

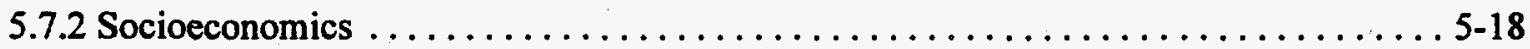

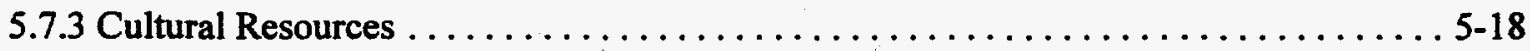

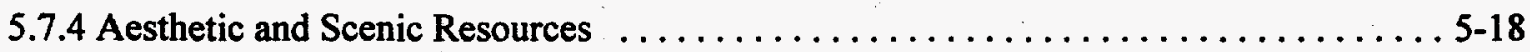

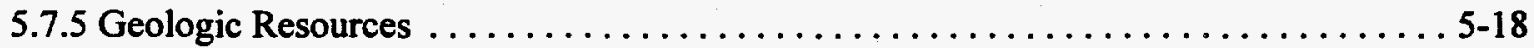

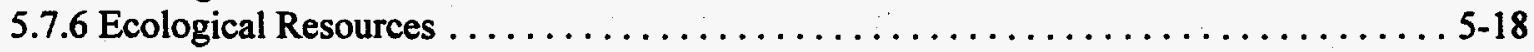

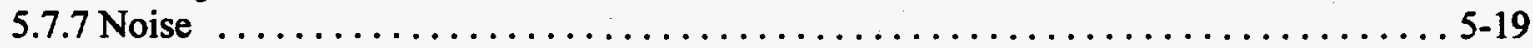

5.7 .8 Site Services . . . . . . . . . . . . . . . . . . . . . . . . . . . 5-19

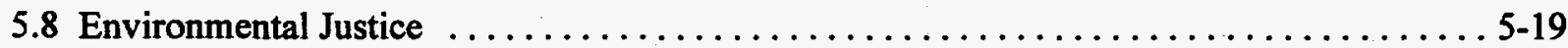

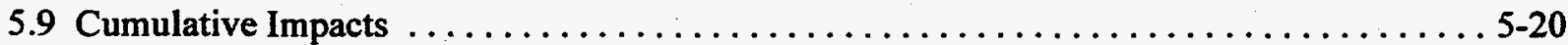

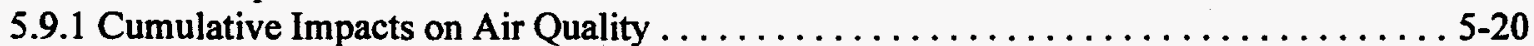

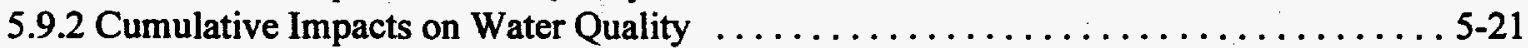

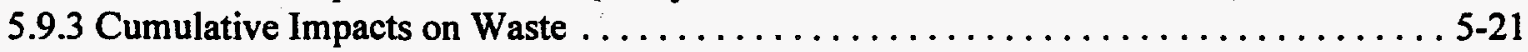

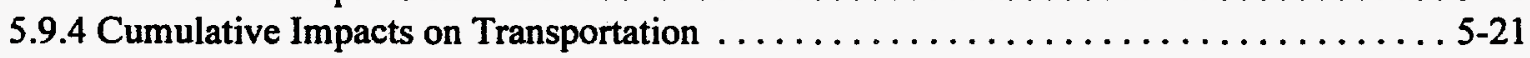

5.9.5 Cumulative Impacts on Health and Safety $\ldots \ldots \ldots \ldots \ldots \ldots \ldots \ldots \ldots \ldots \ldots \ldots \ldots \ldots \ldots \ldots$

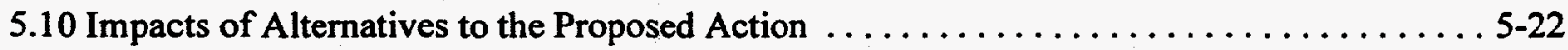

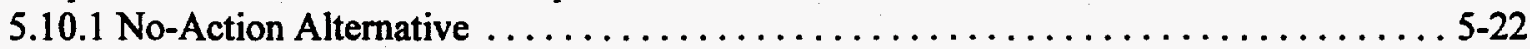

5.10.2 Use of an Alternate Reactor for Irradiation of the TPBAR-LTAs, or Use of Alternate DOE

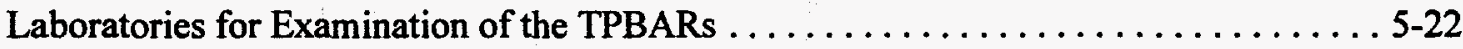

5.10.3 Use of Non-DOE Facilities for Examination of the TPBARs . . . . . . . . . 5-22

6.0 Permits and Regulatory Requirements $\ldots \ldots \ldots \ldots \ldots \ldots \ldots \ldots \ldots \ldots \ldots \ldots \ldots \ldots \ldots \ldots$

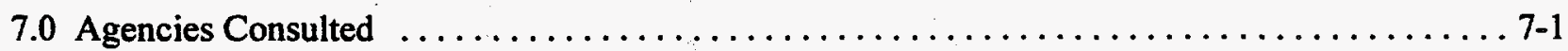

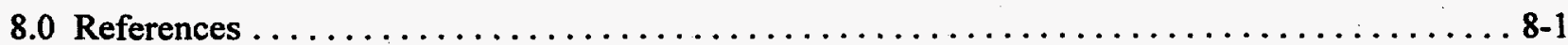




\subsection{Purpose and Need for Agency Action}

The U.S. Department of Energy (DOE) needs to confirm the viability of using a commercial light water reactor (CLWR) as a potential source for maintaining the nation's supply of tritium. The Proposed Action discussed in this environmental assessment is a limited scale confirmatory test that would provide DOE with information needed to assess that option.

\section{Background}

DOE's Programmatic Environmental Impact Statement for Tritium Supply and Recycling (TSR PEIS), described the need for a new source of tritium for defense purposes as summarized in the following (DOE 1995a).

Since nuclear weapons were developed in 1945, a nuclear deterrent has been a cornerstone of the nation's defense policy and national security. Tritium is used to enhance the yield of current nuclear weapons and allows for the production of smaller or more powerful devices. The United States has based its strategic nuclear systems on designs that use tritium and therefore requires a reliable source of this material in order to maintain the nuclear weapons stockpile as required by law.

Tritium has a relatively short radioactive half-life of 12.3 years. Because of this relatively rapid radioactive decay, tritium must be replenished periodically in nuclear weapons to ensure that they will function as designed. Over the past 40 years, DOE has built and operated 14 reactors to produce tritium and other nuclear materials for weapons purposes. Today, none of these reactors is operational, and no tritium has been produced since 1988.

Until a new source of tritium is operational, DOE will continue to meet tritium requirements by recycling tritium from existing weapons as they are retired from the weapons stockpile. However, because tritium decays relatively rapidly, recycling can only meet tritium demands for a limited time. Current predictions of future stockpile scenarios indicate that recycled tritium will adequately support the nation's nuclear stockpile until approximately 2005. (Note: At the time the TSR PEIS was published, a previous assessment of the need for new tritium had placed that date at 2011; the current target date of 2005 is based on a more recent analysis). The tritium supply and recycling facilities as proposed in the TSR PEIS would provide the capability to produce tritium safely and reliably in order to meet the nation's defense requirements well into the 21 st century while also complying with environmental, safety, and health standards.

In the TSR PEIS, DOE proposed several alternatives to provide a new source of tritium for the nuclear weapons program (DOE 1995a). The TSR PEIS evaluated alternatives for the siting, construction, and operation of tritium supply technology and recycling facilities at each of five candidate sites: the Idaho National Engineering and Environmental Laboratory (INEEL) in Idaho, the Nevada Test Site (NTS) in Nevada, the Oak Ridge Reservation (ORR) in Tennessee, the Pantex Plant in Texas, and the Savannah River Site (SRS) in South Carolina.

The TSR PEIS included an analysis of the use of a light water reactor (LWR) as well as the use of an accelerator for production of tritium. As part of the LWR alternative, DOE considered the purchase of an operating or partially completed commercial power reactor, or purchasing irradiation services from an existing CLWR. A combination of the CLWR and accelerator alternatives (one option to serve as the primary tritium source with the other serving as the backup source) was selected in the TSR PEIS Record of Decision (60 FR 63877-63891). A decision is expected by the end of 1998 to determine which option will be the primary source for tritium and which will serve as the backup source. 
This EA tiers from the TSR PEIS and covers only those activities that would be necessary to conduct tests involving irradiation of tritium-producing burnable absorber rods (TPBARs) in a CLWR and postirradiation examination (PIE) of the TPBARs. Aspects of the actual tritium production program or operations at the CLWR used to irradiate the TPBARs are, or would be, addressed by separate NEPA documentation. The commercial reactor proposed to perform the irradiation in this EA may or may not be the reactor selected for actual tritium production in the future. If the CLWR alternative is selected to be a primary or backup tritium source, the selection of the specific reactor(s) eventually used for the production mission would be addressed by a separate site-specific NEPA analysis. 


\subsection{Proposed Action}

The Department of Energy's Proposed Action is described in the following sections.

\subsection{Background}

Irradiation of TPBARs in a CLWR is being evaluated as a reasonable alternative for meeting the need to replenish the supply of tritium for nuclear weapons. It is also being considered as a backup source, should the accelerator alternative be selected as the primary tritium source, in order to ensure that adequate supplies of tritium would be available. The TPBARs used in the proposed tests would both replace and function as a standard burnable absorber assembly in a CLWR. The function of the reactor, the absorber assembly and the TPBARs is described below.

The TPBARs have been designed for use in a pressurized water reactor (PWR) of the type developed commercially by Westinghouse. The LWRs used to generate electric power in the United States utilize both PWR and boiling water reactor (BWR) technologies. However, use of a BWR to produce tritium would require technology different from that involved in using a PWR of the design proposed for this test. Specifically, to produce tritium most BWR designs would require production of specially designed fuel or reconfiguration of the reactor core to accommodate separate tritium targets. As a result of these considerations, and because of the extensive research and development that has already occurred using PWR technology, the Proposed Action described in this EA involves the use of a PWR.

Commercial PWRs produce electricity by creating steam to drive a steam turbine generator. In a typical large PWR, heat is generated by nuclear fission in the reactor core and transferred to the turbine via steam produced in a heat exchanger. The side of the heat exchanger that is connected to the reactor vessel (referred to as the "primary" side) is isolated from the side that supplies steam to the turbine (the "secondary" side of the heat exchanger) so that water in contact with the reactor core is effectively contained within the reactor vessel and the primary side of the heat exchanger under normal operating conditions.

The reactor core contains fuel assemblies, coolant, a neutron moderator (a material that slows neutrons), and devices to control the nuclear fission reaction. In U.S. commercial power reactors, the fuel consists of uranium slightly enriched (less than 5\%) in the fissile isotope uranium-235 (U-235), which is typically fabricated into fuel elements as a series of stacked pellets within a cylindrical metal cladding. A number of individual fuel elements are then bundled into a larger unit, referred to as a fuel assembly, for ease of handling during shipping and refueling.

Water provides both the coolant and neutron moderator functions in a LWR. The moderator in a reactor serves to reduce the energy of neutrons generated by the fission process. The lower energy neutrons are more readily absorbed by U-235 in the fuel to produce additional fissions, thereby sustaining a fission "chain reaction." The primary coolant circulates through the reactor core to remove heat and carry it to the heat exchanger, where the heat is transferred to the secondary coolant (also water in the case of commercial PWRs) which is converted to steam to drive the turbine generator.

The power level in the core of the reactor is regulated in part by devices that contain neutron-absorbing materials, typically cadmium or boron, which prevent neutrons from interacting with fuel to produce fission reactions. These materials are incorporated into "control rods" which can be inserted into spaces within or between the fuel assemblies to control the power level in that region of the core. The control rods are configured in such a way that the nuclear reaction is completely shut down when all of the control rods are fully inserted. 
The power level in the region of new fuel assemblies can also be regulated by incorporating neutron absorbing materials directly into the fuel elements or assemblies, thereby maintaining a more uniform power density throughout the core and extending the useful life of the new fuel elements. The absorbers in the fuel assemblies consist of isotopes that readily absorb neutrons, and in the process are transformed into different isotopes that absorb neutrons less efficiently (hence, they are referred to as "burnable" absorbers). As the active fuel in the assembly is depleted, the neutron absorber in the assembly is also depleted. When a fuel assembly becomes sufficiently depleted of fissile material that it cannot sustain the required power level, it must be removed from the reactor and replaced by a new fuel assembly. CLWRs typically replace part of their fuel on a rotating schedule every 12-18 months, a process referred to as the "refueling cycle."

The fuel assemblies in PWRs of the design proposed for the TPBAR irradiation consist of fuel element lattices that contain spaces in the lattice into which either burnable absorber rods or control rods may be inserted. If the fuel assemblies are to contain burnable absorbers, the absorber material is incorporated into separate rods that fit into the lattice openings. The absorber material used for many commercial PWRs consists of borosilicate glass encased in a stainless steel cladding. The absorber rods are attached to a hold-down plate that, in turn, fits into the top of the fuel assembly. The burnable absorber assemblies can be removed from the fuel assemblies after the fuel has been through one operating cycle. This fuel configuration is convenient for the proposed tests because the TPBARs can be incorporated into fuel assemblies in place of the conventional burnable absorber rods. The major difference between conventional PWR burnable absorber rods and the TPBARs would be the use of a lithium aluminate ceramic as a neutron absorber in place of the standard borosilicate glass. At the end of the operating cycle, the TPBAR assemblies could then be removed from the host fuel assemblies and shipped for examination without the need to transport or handle the irradiated fuel.

When a utility desires to implement design modifications in a commercial reactor that may affect fuel performance or other systems that provide reactivity control (such as substituting TPBARs for the conventional burnable absorber rods), a lead test assembly (LTA) program can be conducted to confirm specific expected behavior in a reactor. An LTA program usually consists of a limited number of assemblies of the proposed new design (typically an even number for symmetry), which are inserted into the reactor core at the beginning of an operating cycle in order to demonstrate satisfactory performance of the components. Such a program is appropriate for the use of TPBARs containing lithium in place of the standard boron neutron absorbers in a PWR burnable absorber assembly.

The Proposed Action expands upon more than ten years of DOE research and development activities associated with tritium production targets for LWRs. As part of this research, target irradiation, PIE, and safety testing has been performed entirely at DOE facilities. During the Proposed Action, the NRC would oversee activities that take place at its licensee facilities. The NRC has reviewed a technical report prepared by DOE to document the performance and safety basis for the TPBAR design (Erickson et al 1997), and has issued a safety evaluation report with regard to the proposed tests. (NRC 1997).

\subsection{Description of the Proposed Action}

The Proposed Action would confirm the results of developmental testing conducted previously at DOE facilities and provide DOE with information regarding the actual performance of the TPBARs in a CLWR. It would also demonstrate that tritium production could be carried out within the normal operating and regulatory constraints associated with a commercial nuclear power facility, without affecting the plant's safety systems, production capacity, or normal operations. These activities would provide added confidence to the utilities and the NRC, which regulates commercial power reactors, that tritium production in a CLWR could meet national security needs in a technically straightforward, safe and cost effective manner. 
Activities associated with the Proposed Action include replacing four conventional PWR burnable absorber assemblies with assemblies containing the TPBARs (referred to as TPBAR-LTAs) during the next refueling outage at the Watts Bar Nuclear plant (WBN), Unit 1 (operated by the Tennessee Valley Authority (TVA)) in southeastern Tennessee. See Figure 2.1 for a graphical depiction of the Proposed Action. The TPBARs would be shipped from the Hanford Site near Richland, Washington to the Westinghouse fuel fabrication facility in Columbia, South Carolina, for assembly into TPBAR-LTAs (see Figure 2.2). The TPBAR-LTAs would be inserted into four new fuel assemblies at Westinghouse. The fuel assemblies with the TPBAR-LTAs (hereafter referred to as "integrated assemblies") would then be shipped to WBN with the rest of the new fuel and stored until the next refueling outage, when they would be inserted into the reactor. A typical fuel reload would contain more than 1000 burnable absorber rods, of which 32 would be replaced by the TPBARs in the proposed test.

The TPBAR-LTAs would be irradiated for one complete operating cycle (approximately 18 months), following which they would be removed from the integrated assemblies and stored in the spent fuel pool. The fuel assemblies would be placed back in the reactor as part of the refueling process. The TPBARLTAs would be shipped to the Pacific Northwest National Laboratory (PNNL) at Hanford for postirradiation examination (PIE). Because the fuel assemblies from the integrated assemblies could be returned to the reactor core during refueling, no shipment or disposal of spent nuclear fuel would be required as part of the Proposed Action.

As part of the PIE activities at Hanford, the TPBARs would be removed from the remaining hardware. The TPBARs would then be subjected to non-destructive evaluation (NDE), including a visual inspection and gamma radiography. The TPBARs would also be punctured to collect and analyze any gases that accumulate during irradiation, and the penetrations would be sealed before the TPBARs are stored or processed further.

After the initial NDE at PNNL, the TPBARs may also be examined by neutron radiography at a facility yet to be determined. For the purposes of this analysis, neutron radiography was assumed to take place at the Hot Fuels Examination Facility (HFEF) located at the Argonne National Laboratory-West (ANL-W) near Idaho Falls, Idaho. Upon completion of the neutron radiography, the TPBARs would be returned to PNNL for destructive examination. For this evaluation, laboratory wastes that result from the destructive examinations, intact spent TPBARs, and residual equipment and materials that remain from cleaning out the facilities are assumed to be dispositioned as waste at the Hanford Site. The small quantities of radioactive waste that may be generated at other locations would be disposed with similar wastes from those facilities. Additional information about each phase of the Proposed Action is provided in the following sections.

\subsubsection{Pre-Irradiation Transport and Assembly of TPBAR-LTAs}

Initially, the TPBARs would be shipped from the Hanford Site to the Westinghouse fuel fabrication facility for assembly into the TPBAR-LTAs and integrated assemblies. Prior to placement in the reactor, the TPBARs are not radioactive nor do they contain hazardous materials as defined by the Department of Transportation (DOT) in 49 CFR Part 171-178. (Figure 2.3 depicts transportation route options for the Proposed Action.)

Thirty-two TPBARs (plus a limited number of spares) would be required for the Proposed Action. General information regarding the TPBAR design is included in this section; Appendix A contains additional information. The exterior dimensions of the TPBAR are compatible with those of a standard Westinghouse burnable absorber rod - approximately 0.381 inch $(1 \mathrm{~cm})$ in diameter and 152 inches (390 $\mathrm{cm}$ ) long. The TPBARs contain lithium aluminate absorber in the form of stacked cylindrical elements, a Zircaloy-4 liner, and a nickel-plated zirconium "getter" to trap and retain the tritium in a solid matrix. The getter is an effective mechanism to contain the tritium. In fact, it is extremely difficult to extract the tritium 
from the getter which requires very high temperatures for an extended period of time. The TPBAR cladding consists of Type 316 stainless steel with a wall thickness of 0.0225 inch $(0.057 \mathrm{~cm})$. The cladding also has an aluminum coating to minimize permeation of hydrogen through the cladding. The TPBAR end plugs are of a standard Westinghouse design and are seal-welded in place.

At the Westinghouse fuel fabrication facility, 8 TPBARs and 16 thimble plugs would be attached to a hold-down assembly to make up a single TPBAR-LTA (which contains 24 possible burnable absorber rod locations). Figure 2.2 depicts the TPBAR-LTA. Each TPBAR-LTA would undergo a standard acceptance inspection before incorporating it into an integrated fuel assembly. Four TPBAR-LTAs would be prepared, each of which would be placed into one fuel assembly to provide the four integrated assemblies required for the LTA program. The integrated assemblies containing the TPBAR-LTAs would be loaded into standard unirradiated fuel shipping containers and transported to WBN. The shipments would likely utilize a commercial carrier authorized to transport radioactive materials of low-specific-activity on interstate highways.

\subsubsection{Irradiation}

The integrated assemblies containing the TPBAR-LTAs would be received at WBN and transported through the truck bay door, into the truck bay, and through the truck bay overhead hatches to the refueling floor. The integrated assemblies and the rest of the new fuel would undergo a receiving inspection, following which they would be stored in preparation for loading into the reactor core during the refueling outage.

The TPBAR-LTAs would remain in the core for one operating cycle and would receive approximately 450 to $\mathbf{5 5 0}$ effective full power days of exposure. After one cycle of irradiation, during the next refueling outage, the integrated assemblies would be removed from the reactor core and transported under water to the spent fuel pool. The TPBAR-LTAs would then be removed from the integrated assemblies, and the fuel assemblies that held the TPBAR-LTAs would be reloaded into the reactor core with the new reload fuel.

\subsubsection{Post-Irradiation Transportation}

Following the refueling, an NRC-certified Type B shipping cask would be shipped to WBN and transported to the spent fuel pool floor through the previously described path. No cool down period is necessary for transport of the TPBAR-LTAs; therefore, the shipment would likely occur after the refueling outage to minimize operational impacts on the WBN restart. The cask would be placed in the fuel cask loading area in the spent fuel pool, and one or two of the TPBAR-LTAs would be loaded into the cask under water. The loaded cask would be lifted out of the spent fuel pool and moved to the cask wash down area. The cask would be washed down, drained, decontaminated, transported to the truck bay, and loaded on a truck. Up to 4 exclusive use shipments would be used to transport the cask containing the irradiated TPBAR-LTAs to the 325 Building at Hanford.

\subsubsection{Post-Irradiation Examination}

Post-irradiation examinations would be performed at the Hanford Site 325 Building and possibly at a neutron radiography facility to be identified in the future. PNNL would conduct all PIE activities other than the neutron radiography.

The 325 Building in the Hanford Site 300 Area houses a variety of laboratories, three hot cells and a cask unloading gallery in the rear of the cells. (See Figure 2.4) Some construction would be necessary in order to accept and unload the shipping cask at the 325 Building. The construction would consist of making a 
new penetration in the south wall of the " $A$ " hot cell and installing an access door. Some additional modifications would be required to relocate a stairway inside the building but external to the hot cell. However, all of the planned construction activities would be performed inside the current building footprint, and no construction external to the building would be required.

After the cask is unloaded at the Hanford 325 Building, the TPBAR-LTAs would be moved to the " $A$ " cell facility through the new access port. The TPBAR-LTAs would be disassembled inside the "A" cell, and all ancillary hardware (such as the hold down assembly, attachment nuts, and thimble plugs) would be packaged and dispositioned as low level radioactive waste. The TPBARs would undergo an initial nondestructive evaluation, including a visual inspection and gamma radiography. All of the TPBARs may then be punctured to collect and analyze any gases that accumulated during irradiation, and the penetrations would be resealed prior to storage or further handling.

If neutron radiography is to be performed, all of the TPBARs would be loaded into an NRC-certified Type $B$ shipping cask and transported to the neutron radiography facility for additional non-destructive examination. The HFEF at ANL-W was analyzed as a representative location for this activity. The HFEF is used by DOE for neutron radiography on a variety of materials including components similar to the TPBARs. The HFEF can only radiograph a 9' 6" $(2.9 \mathrm{~m})$ length; thus each rod would be flipped end-toend such that a radiograph of the full length of the rod can be obtained. Upon completion of neutron radiography, the TPBARs would be reloaded into the shipping cask and returned to Hanford.

The TPBARs would be stored in sealed containers within the 325 Building hot cell facility until they are removed for destructive examination. Destructive examination of the TPBARs involves 2 major activities:

- Sectioning the TPBARs into small pieces to examine structural changes in the cladding and internal components as a result of irradiation and

- Extracting tritium from the TPBARs to determine production and recovery levels.

For sectioning, at least one TPBAR from each TPBAR-LTA would be moved into the "B" cell facility and cut in preparation for examination. Helium, lithium, tritium, and protium assays would be performed on various sections from the TPBARs. Metallographic examinations would also be performed on various components including the cladding. Extraction of tritium from the TPBARs involves puncturing and heating the TPBARs in a closed system to drive off tritium trapped in the solid components. The gases are then collected and analyzed to determine the quantity and chemical state of recovered tritium. In addition to the PIE tests, additional experiments to evaluate the permeability of the TPBAR cladding material to tritium would also be conducted using tritium from a commercial source. Examination of small samples from the TPBARs may take place in other laboratories within the 325 building or at another appropriate laboratory in the 300 Area. Depending on the results of the destructive examinations, additional TPBARs (up to all 32) may be selected for further examination.

\subsubsection{Interim Storage and Waste Disposition}

Any TPBARs that are not subjected to destructive examination would be stored at Hanford until another use for them is identified or DOE decides to dispose of them. Prior to disposal, the tritium would be extracted from any remaining intact TPBARs and recovered for other purposes or packaged separately for disposal.

Preparation of the integrated assemblies at the Westinghouse fuel fabrication facility would not produce any radioactive or hazardous wastes in addition to those typically generated at the facility. Wastes associated with irradiation of the integrated assemblies at WBN would consist of low-level radioactive liquids and solids generated as the TPBAR-LTAs are removed from the spent fuel pool and packaged for 
shipment to Hanford. These wastes would be treated as appropriate and disposed of at an NRC-licensed commercial facility with wastes from routine operations at WBN.

Wastes produced during disassembly of the TPBAR-LTAs and NDE of the TPBARs at Hanford would consist of laboratory materials and protective clothing used to prevent possible spread of contamination during receipt, handling, and examination. Those wastes would be disposed of at Hanford in facilities appropriate to the waste type. Likewise, any radioactive waste generated by neutron radiography at ANLW would consist of small quantities of laboratory materials used to survey the shipping cask for external contamination and disposable protective clothing such as gloves. Waste generated during activities at ANL-W would be managed onsite at the INEEL.

The quantities of low-level radioactive waste generated during PIE of the TPBARs at Hanford would consist of cuttings and small sections of the cladding and internal components, laboratory materials used to control spread of contamination, and either solid molecular sieve or bubbler liquids used to trap the tritium contained in gaseous effluents from the sectioning and extraction processes. Smaller quantities of mixed low-level waste could be produced during liquid scintillation counting of tritium samples, and a small quantity of nonradioactive hazardous wastes would be produced during the laboratory activities as well. Additional radioactive wastes would result from decontamination of the hot cells and removal of unneeded equipment after the work is completed. All radioactive and hazardous wastes generated at Hanford would be disposed of either at the onsite burial grounds or in permitted commercial disposal facilities in accordance with applicable state and federal regulations. Mixed low-level wastes would be stored onsite in permitted facilities. Section 5.3 of this EA contains additional information concerning waste management. 


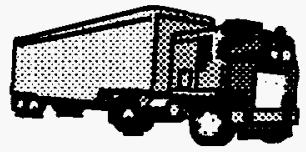

1 TPBARs will be sent from Hanford, Washington to Westinghouse, Columbia, South Carolina to be inserted in four fuel assemblies

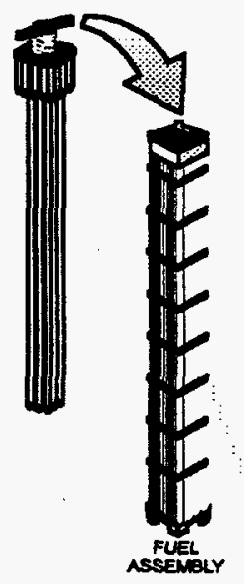

2 Integrated assemblies are sent to Watts Bar Nuclear Plant, Tennessee

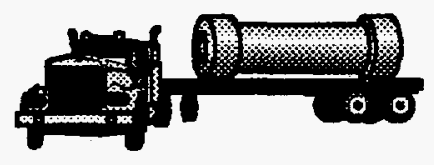

6 TPBARs returned to Hanford for further post-irradiation examination

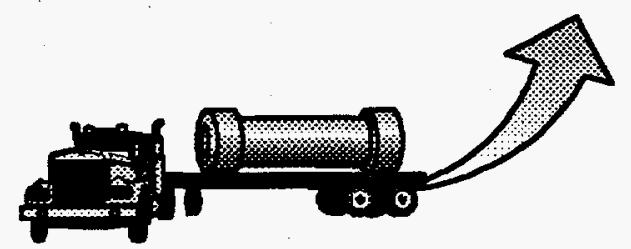

${ }^{5}$ Separated TPBARs shipped to facility for neutron radiography
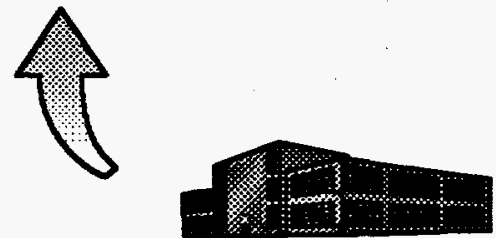

4 TPBAR-LTAs shipped to Hanford for disassembly and examination

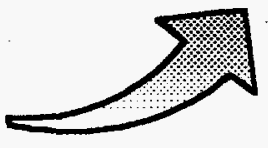

3 integrated assemblies to be irradiated for one operating cycle in the Watts Bar Nuclear Plant

Figure 2.1 General Depiction of the Proposed Action 


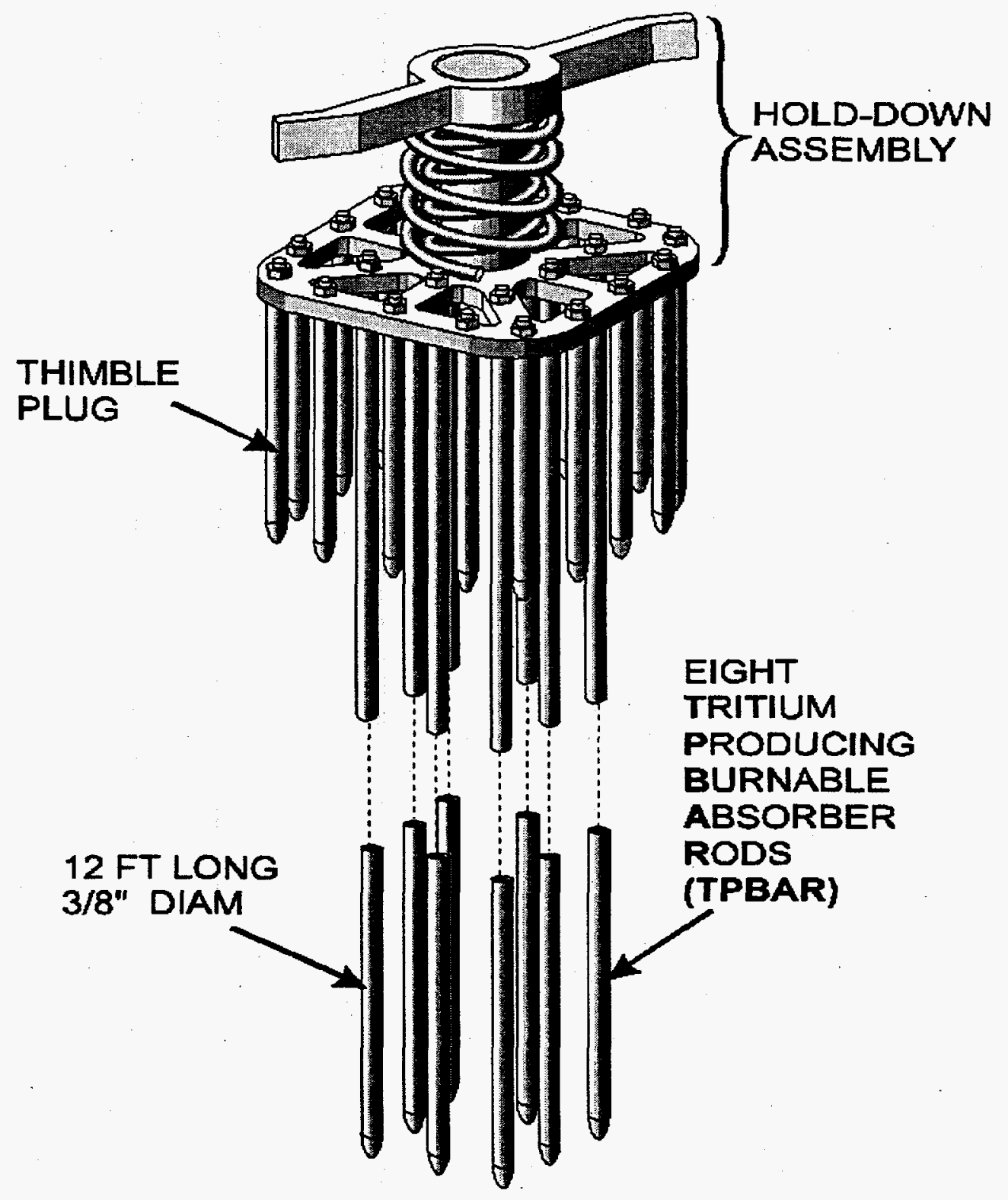

Figure 2.2 Tritium Producing Burnable Absorber Rods - Lead Test Assembly (TPBAR-LTA) 


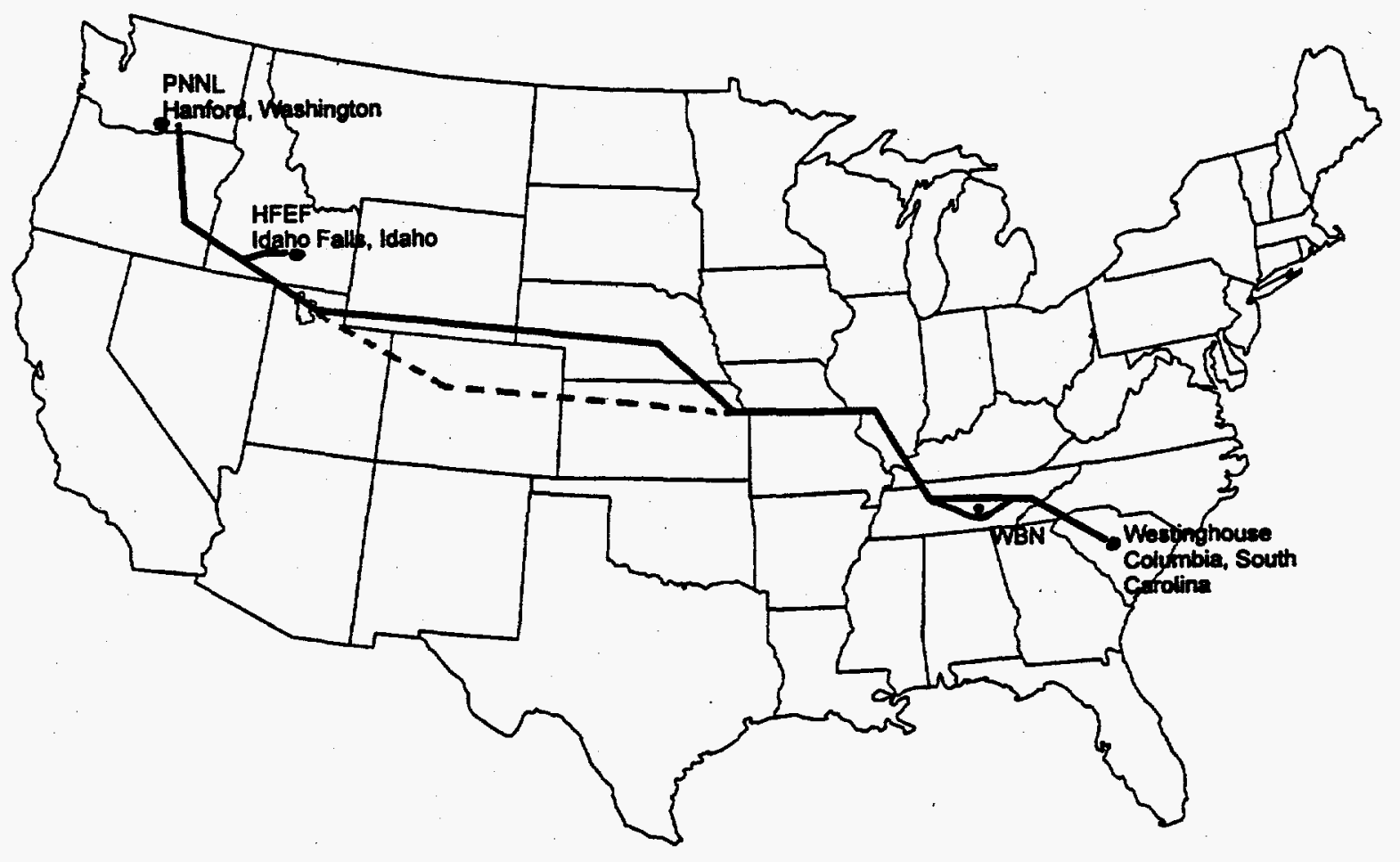

- Proposed Transportation Route

Figure 2.3 Proposed Action Transportation Routes 


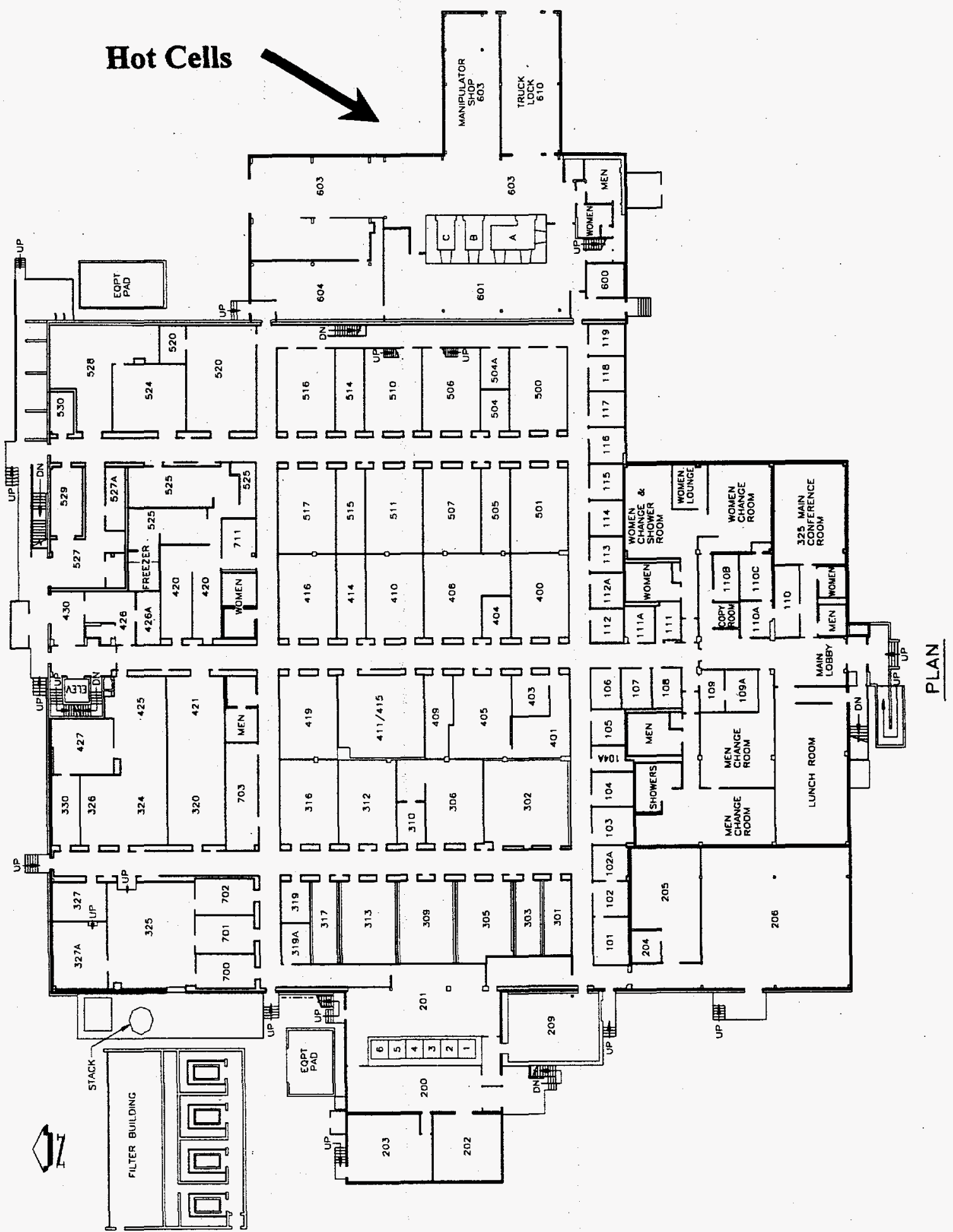

Figure 2.4 Hanford Site 325 Building and Hot Cells 


\subsection{Alternatives to the Proposed Action}

The Department has considered three alternatives to the Proposed Action, including: no action; irradiation at another reactor, with analysis at other DOE laboratories; and use of a private hot cell facility to analyze the irradiated TPBARs. Each alternative is discussed in this section.

\subsection{No Action}

Under a no-action alternative, DOE would not conduct the LTA program or post-irradiation examinations. The final selection of either a CLWR or an accelerator as the nation's primary tritium source would be made without the benefit of the results of this proposed project. The no-action alternative is not consistent with the purpose and need. However, evaluation of the No Action alternative is required by NEPA as a baseline against which to assess the impacts of the Proposed Action and alternatives.

\subsection{Irradiation at Other Reactor/Analysis at Other DOE Laboratory}

DOE has considered the use of another commercial reactor to conduct the LTA program, as well as the use of other DOE laboratory facilities for examining the TPBARs. WBN was proposed for these tests because its refueling schedule provided optimum timing for obtaining the performance data needed by DOE, and because it was the only reactor of compatible design that was not encumbered by vendor restrictions on use of its fuel or other components for defense-related research. All other U.S. PWRs of this design obtain their fuel from foreign vendors that impose contractual restrictions on use of their products for defenserelated purposes. Use of any facility other than WBN would have required DOE to replace all of the reactor's fuel, resulting in possible delay of the tests as well as substantially increased cost. Therefore, DOE considered options other than use of WBN to be unreasonable for the proposed tests. A future, separate evaluation process would identify one or more facilities for the actual tritium production mission. Reactors owned by DOE (such as the Fast Flux Test Facility [FFTF] at Hanford or the Advanced Test Reactor at the INEEL) or reactors operated by universities do not meet the purpose and need for the Proposed Action, which is to demonstrate the viability of producing tritium in a CLWR.

Other DOE laboratories could perform the post-irradiation activities if the technology were transferred to those laboratories, and if the laboratories possessed hot cells large enough to contain the full length of the TPBAR-LTAs. This alternative was not considered reasonable because Hanford has the technology for post-irradiation examination of the TPBARs. Further, Hanford has hot cells suited for this purpose and has conducted similar types of examinations in the past. Use of alternate facilities would introduce technical uncertainties and impact both the schedule and cost for the proposed tests; therefore, this alternative has not been evaluated in detail.

\subsection{Examination at a Private Facility}

DOE has also considered the use of a private hot cell facility to conduct the examination on the irradiated TPBARs. However, hot cells with the ability to handle the quantities of radioactive materials involved and to accommodate the full-length assemblies are generally not available outside the DOE complex. The exception would be a commercial nuclear fuel fabrication facility which is owned by a foreign corporation. However, the security measures required to perform the work in a foreign-owned facility would be difficult to implement. For these reasons, use of non-DOE facilities is not evaluated in detail. 



\subsection{Affected Environment}

This section provides an overview of the environmental characteristics of the Hanford Site, WBN, and the ANL-W facilities, as well as site-specific characteristics of Hanford's 300 Area where most of the proposed post-irradiation examination activities would take place. Additional information about the Hanford Site can be found in the Hanford Site National Environmental Policy Act (NEPA) Characterization (Neitzel 1996), and the WBN environment is described in the Final Environmental Statement related to the Operation of Watts Bar Nuclear Plant, Units 1 and 2 (NRC 1995).

\subsection{Hanford Site Description}

The proposed analysis activities would take place in the 300 Area of the Hanford Site. (See Figure 4.1) The Hanford Site covers 1450 square kilometers ( 560 square miles) of south-central Washington State. It is a semi-arid region of rolling topography, with some trees along the Columbia River. Two topographical features dominate the landscape: Rattlesnake Mountain, a treeless 1074-meter ( $3525 \mathrm{feet}$ ) anticline located on the southwest boundary, and Gable Mountain, a small ridge 339 meters (1,112 feet) high, located on the northern portion of the Site.

The Hanford Site is located in the Pasco Basin, one of the structural and topographic basins of the Columbia Plateau. Thick basalt flows (greater than 3650 meters [12,000 feet] thick) underlie sedimentary material consisting of silts, sands, and gravel (Hanford Formation and Ringold Formation). The sedimentary deposits are moisture deficient and have a high capacity to adsorb and retain cations (Neitzel 1996).

The Columbia River, the dominant river in the region, flows through the northern part of the Hanford Site and forms part of the Hanford Site's eastern boundary. An 84-kilometer (52-mile) stretch of the Columbia River between the 300 Area and Priest Rapids Dam (river mile 345 to 396) is known as the Hanford Reach. This section of the river has been evaluated by the National Park Service for possible inclusion in the National Wild and Scenic Rivers system, but no final action has been taken by Congress.

The Hanford Site is a shrub-steppe community of sagebrush and rabbitbrush, with an understory consisting primarily of cheatgrass and Sandberg's bluegrass. More than 300 species of insects, 39 species of mammals, 36 common species of birds, and 12 species of reptiles and amphibians have been identified on the Hanford Site.

Areas adjacent to the Hanford Site are primarily agricultural lands. The city of Richland, Washington (population 32,315), located in Benton County, adjoins the southernmost portion of the Hanford Site boundary and is the nearest population center.

The leading employers who affect the local economy are the DOE and its contractors; the Washington Public Power Supply System; and the agricultural sector, including food processing plants. Other major employers include a nuclear fuel fabrication plant, a meat packing plant, a pulp and paper mill, railroad, and small manufacturing firms.

Non-DOE facilities located at the Hanford Site include a commercial nuclear power plant operated by the Washington Public Power Supply System (WNP-2) and a commercial low-level radioactive waste disposal facility administered by the State of Washington and operated by U.S. Ecology, Inc. A privately owned specialty metal products fabrication enterprise is also located in a former DOE facility at the north end of the 300 Area. 
Government facilities located on the Hanford Site include the following: waste management facilities (solid and liquid wastes), nuclear materials storage facilities, research laboratories, decontamination facilities, a research reactor (the FFTF, which is now on standby status), and deactivated facilities. Also, nine inactive production reactors and three inactive spent fuel reprocessing plants exist on the site.

During 1995, DOE facilities at the Hanford Site discharged approximately $6.7 \mathrm{Ci}$ of tritium to the atmosphere, most of which originated in the 300 Area. Other atmospheric releases of radionuclides amounted to about $80 \mathrm{Ci}$ of radon, $0.0007 \mathrm{Ci}$ of transuranic isotopes, and $0.01 \mathrm{Ci}$ of other fission and activation products. These estimated emissions did not result in air concentrations at the site perimeter that were statistically elevated compared with background concentrations at distant communities, with the exception of air concentrations for I-129. The Hanford Site complied with all federal, state, and local standards for radiological and nonradiological air quality in 1995 (Dirkes and Hanf 1996).

In addition to emissions from DOE facilities, the WNP-2 commercial nuclear power facility at Hanford discharges radionuclides to the atmosphere. In 1993, a year when the plant was operating at near capacity, these emissions amounted to $150 \mathrm{Ci}$ of tritium, $140 \mathrm{Ci}$ of noble gases, and $10 \mathrm{Ci}$ of other fission and activation products (Tichler et al 1995).

Radioactive and hazardous wastes generated at the Hanford site in 1995 amounted to 1900 metric tons (4.2 million lb) of radioactive waste, 130 metric tons of mixed radioactive and hazardous waste, and 800 metric tons (1.8 million $\mathrm{lb}$ ) of hazardous solids and liquids. Those radioactive and mixed wastes contained about $27,000 \mathrm{Ci}$ of tritium, 44,000 $\mathrm{Ci}$ of activation products, and 34,000 $\mathrm{Ci}$ of other radionuclides (Dirkes and Hanf 1996). Low-level radioactive wastes are buried onsite in the 200 Areas, and mixed wastes are stored in permitted facilities in the 200-W Area. Nonradioactive hazardous wastes are shipped offsite for treatment and disposal at permitted facilities.

\subsection{The 300 Area of the Hanford Site}

The 300 Area of the Hanford Site is north of the city of Richland and is contiguous to the Columbia River (see Figure 4.2). The 300 Area served as the research and development center and housed fuel fabrication facilities during the operational phase of the Hanford Site's production reactors. The 325 Building is located about 1.9 kilometers (1.2 miles) north of Richland and $1.3 \mathrm{~km}(0.8 \mathrm{mile})$ from the far shore of the Columbia River.

The 300 Area of the Hanford Site is characterized by relatively cool, mild winters and warm summers with an average of about 15 to 18 centimeters (6 to 7 inches) of annual precipitation and occasional high winds of up to 129 kilometers ( 80 miles) per hour. No tornados have been reported on site; the area has low to moderate seismicity.

The terrestrial and aquatic ecology of the 300 Area closely resembles those ecological characteristics associated with being near the Columbia River. In this area, communities of willow-riparian vegetation are prominent. California quail, Chinese ring-necked pheasants, and mammals such as raccoons, beavers, and porcupines are likely to be found near the river. A Biological Review was completed for the 300 Area in May 1996 (see Appendix B).

\subsection{Watts Bar Nuclear Plant}

The following has been excerpted from the Final Safety Analysis Report for WBN (TVA 1991). 
WBN occupies approximately 710 ha (1770) acres in Southeastern Tennessee (see Figure 4.3). The facility is situated on the west shore of Chickamauga Lake and is approximately $80 \mathrm{~km}$ (50 miles) northeast of Chattanooga and $50 \mathrm{~km}$ (31 miles) northeast of the Sequoyah Nuclear Plant site.

The plant is located in the Valley and Ridge Province of the Appalachian Highlands. The province is made up of a series of folded and faulted mountains and valleys which are underlain by Paleozoic sedimentary formations totaling $12,000 \mathrm{~m}(40,000 \mathrm{ft})$ in thickness. The plant site is situated in a bend of the Tennessee River that has been covered by alluvial terrace deposits. Beneath these deposits lies the Middle Cambrian Conasauga Formation, an interbedded shale and limestone unit upon which the Category I structures are founded.

The controlling feature of the geologic structure at the site is the Kingston thrust fault, which developed 250 million years ago. The fault has been inactive for many millions of years, and recurrence of movement is not expected. The fault lies to the northwest of the site area and is not involved in the foundation for any of the major plant structures.

WBN was designed based on the largest historic earthquake to occur in the Southern Appalachian Tectonic Province - the 1897 Giles County, Virginia earthquake. This earthquake is estimated to have had a body wave magnitude of 5.8. The Safe Shutdown Earthquake for the plant has been established as having a maximum horizontal acceleration of $0.18 \mathrm{~g}$ and a simultaneous maximum vertical acceleration of $0.12 \mathrm{~g}$.

Because of the contours of the land and strata there is little likelihood of abnormal releases of liquid wastes at the plant contaminating industrial or drinking water supplies derived from ground water sources.

No known meteorological measurements other than rainfall have been recorded in the immediate vicinity of the Watts Bar site. Therefore, the climatological appraisal of the site has been developed from meteorological data collected at stations within $80 \mathrm{~km}(50 \mathrm{mi})$. A permanent onsite meteorological facility has been in operation since May 1973 to meet NRC requirements. The FSAR indicates that there are no limiting meteorological factors present at the site.

The population density of the area surrounding the site is relatively low, and only two cities within $100 \mathrm{~km}$ $(60 \mathrm{mi})$ of the plant (Chattanooga and Knoxville) have populations exceeding 100,000 people.

Radionuclide emissions to the atmosphere from WBN were estimated to consist of $13,000 \mathrm{Ci}$ of noble gases and $0.34 \mathrm{Ci}$ of iodine-131 per year with both units operating (NRC 1995). Because only one of the units is currently operational, the atmospheric emissions are estimated to be approximately half of those reported for both units, or $6500 \mathrm{Ci}$ of noble gases and $0.17 \mathrm{Ci} / \mathrm{yr}$ of iodine-131. WBN has been operating for less than 1 year; therefore, results of annual effluent monitoring and ambient air quality monitoring are not yet available. However, the impacts of these emissions are expected to be well within NRC and EPA standards.

Liquid effluents discharged from WBN are regulated by the State of Tennessee under a permit issued in accordance with the federal Clean Water Act. These effluents are not expected to affect water quality in the Tennessee River or to limit public uses of the waterway. Annual releases of radionuclides in liquid effluents were estimated to amount to $2600 \mathrm{Ci}$ of tritium and $6.6 \mathrm{Ci}$ of other radionuclides when both units are operating (NRC 1995). The estimated emissions for operation of one unit are therefore about 1300 $\mathrm{Ci} / \mathrm{yr}$ of tritium and $3.3 \mathrm{Ci} / \mathrm{yr}$ of other radionuclides. These emissions are also expected to be well within federal and state standards for members of the public.

Low-level radioactive wastes generated at WBN for operation of both units are expected to amount to 150 $\mathrm{m}^{3}\left(200 \mathrm{yd}^{3}\right)$ of ion exchange resins and filters, $40 \mathrm{~m}^{3}\left(53 \mathrm{yd}^{3}\right)$ of other dry waste (after compaction), and 3 
$\mathrm{m}^{3}\left(4 \mathrm{yd}^{3}\right)$ of irradiated components per year (NRC 1995). Radioactive wastes generated at the plant are shipped to a commercial facility licensed by the NRC for disposal.

\subsection{Argonne National Laboratory-West}

Argonne National Laboratory-West (ANL-W), located at a desert site in Idaho on the INEEL, is part of the Argonne National Laboratory (ANL). ANL is a non-profit research Laboratory operated by the University of Chicago for the Department of Energy.

The ANL-W and INEEL are located in southeastern Idaho, about $44 \mathrm{~km}(27 \mathrm{mi})$ west of Idaho Falls (Figure 4.4). ANL-W is located in the southeast portion of the site, approximately $8.7 \mathrm{~km}$ from the site boundary. The northern and western borders of the INEEL site are roughly formed by the Bitterroot, Lemhi, and Lost River mountain ranges. The site encompasses $2312 \mathrm{~km}^{2}\left(893 \mathrm{mi}^{2}\right)$ in Butte, Bingham, Jefferson, Bonneville, and Clark counties, Idaho. About $145 \mathrm{~km}(90 \mathrm{mi})$ of paved public highways run through the INEEL site, including U.S. highways 20 and 26 , and state routes 22 , 28 , and 33. Other transportation routes include Interstate 15 and U.S. highways $93 \mathrm{~A}$ and 191.

The INEEL is located in southeastern Idaho with Mud Lake to the east; Arco, Butte City, and Howe to the west; and Atomic City to the south. The larger communities of Idaho Falls, Rexburg, Blackfoot, Pocatello, and Chubbock are to the east and southeast of the INEEL site. The Fort Hall Indian Reservation is to the southeast of the INEEL. The Bitterroot, Lemhi, and Lost River mountain ranges border the INEEL site on the north and west. Most of the INEEL site consists of open undeveloped land, covered predominantly by large sagebrush and grasslands. Pasture and irrigated farmland border much of the INEEL site. The Craters of the Moon National Monument is about $24 \mathrm{~km}$ (15 mi) southwest of the INEEL site western boundary.

Examinations conducted in the Hot Fuels Examination Facility (HFEF) provide data that are essential for determining the performance of fuels and materials irradiated in the Experimental Breeder Reactor II (EBR-II), Transient Test Facility (TREAT), and other DOE reactor facilities. HFEF, which went into operation in 1975, consists of two shielded hot cells, the decontamination cell which contains an air atmosphere and the main cell which contains an argon gas atmosphere. Both cells are surrounded by high-density concrete walls, four feet thick, that protect workers from the high radiation levels present in the cells. Each of the twenty-one workstations in HFEF are equipped with shielded windows (also four feet thick) and master/slave manipulators. The main cell, with its inert argon gas atmosphere, is utilized for work involving exposure of materials such as sodium, plutonium, and other materials that would react chemically with air.

HFEF has several features that make it suited for examining irradiated fuels and materials experiments. The main cell is designed for containment of any plutonium contamination that may be released during the handling and examination of irradiated experiments. The cell is also designed for the vertical handling, cutup, and examination of experiments up to about $9 \mathrm{~m}(30 \mathrm{ft})$ in length. Much of the in-cell examination equipment for fuel elements is automated or semi-automated. All of the in-cell equipment is carefully designed to permit remote maintenance. No personnel entry has been required into the main cell.

Non-destructive in-cell examination capabilities include macro viewing and photography, weighing, precision dimensional surveys, gamma-ray spectroscopy, eddy-current testing, neutron radiography, and fission-gas sampling and assay. Destructive examination capabilities include in-cell equipment for cutting specimens from irradiated hardware or fuel and the preparation of samples for physical testing, chemical analysis. or microscopic examinations. Samples in the main cell are transferred by pneumatic "rabbit" to the ANL-W Analytical Laboratory or to a small HFEF hot cell, where optical microscopy and scanning electron microscopy are available. 
The capability to examine and characterize contact-handled transuranic waste destined for the Waste Isolation Pilot Plant in New Mexico was added to HFEF in 1990. A 250-kW research reactor is located in the basement of HFEF and provides a source of neutrons for neutron radiography. The Neutron Radiography Facility is equipped with two beam tubes and two separate radiography stations.

Specimens are lowered from the HFEF main cell to intersect one of the collimated neutron beams. The second neutron radiography station is outside of the main cell and permits neutron radiography of either unirradiated or irradiated specimens without introducing them into the contaminated main cell.

Other HFEF features include: a computer system for data acquisition and in-cell process control; a microdensitometer that supports neutron tomography (a process similar to medical CAT scanning); and facilities for decontaminating and repairing hot cell equipment and manipulators. 


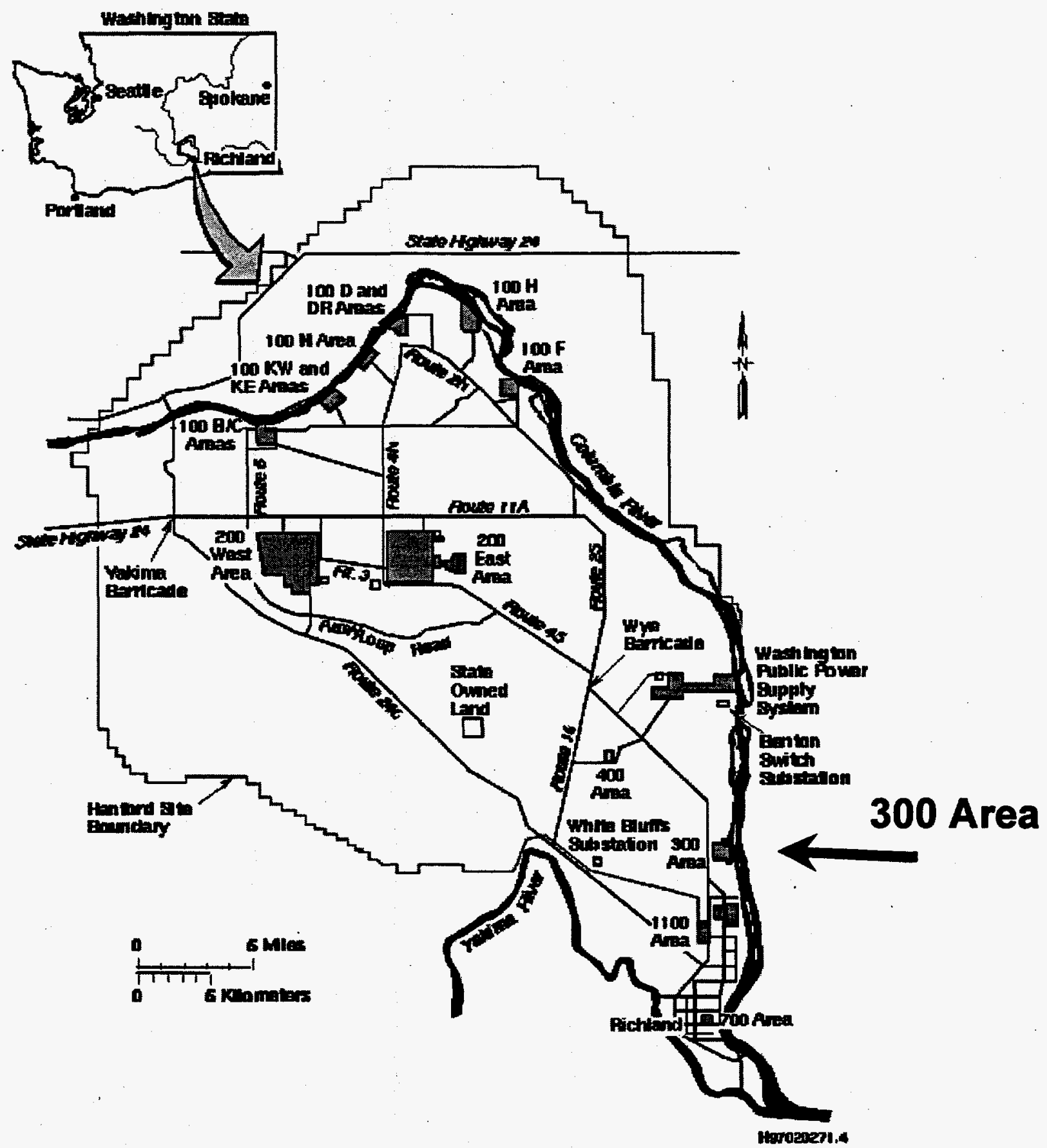

Figure 4.1 Hanford Site 


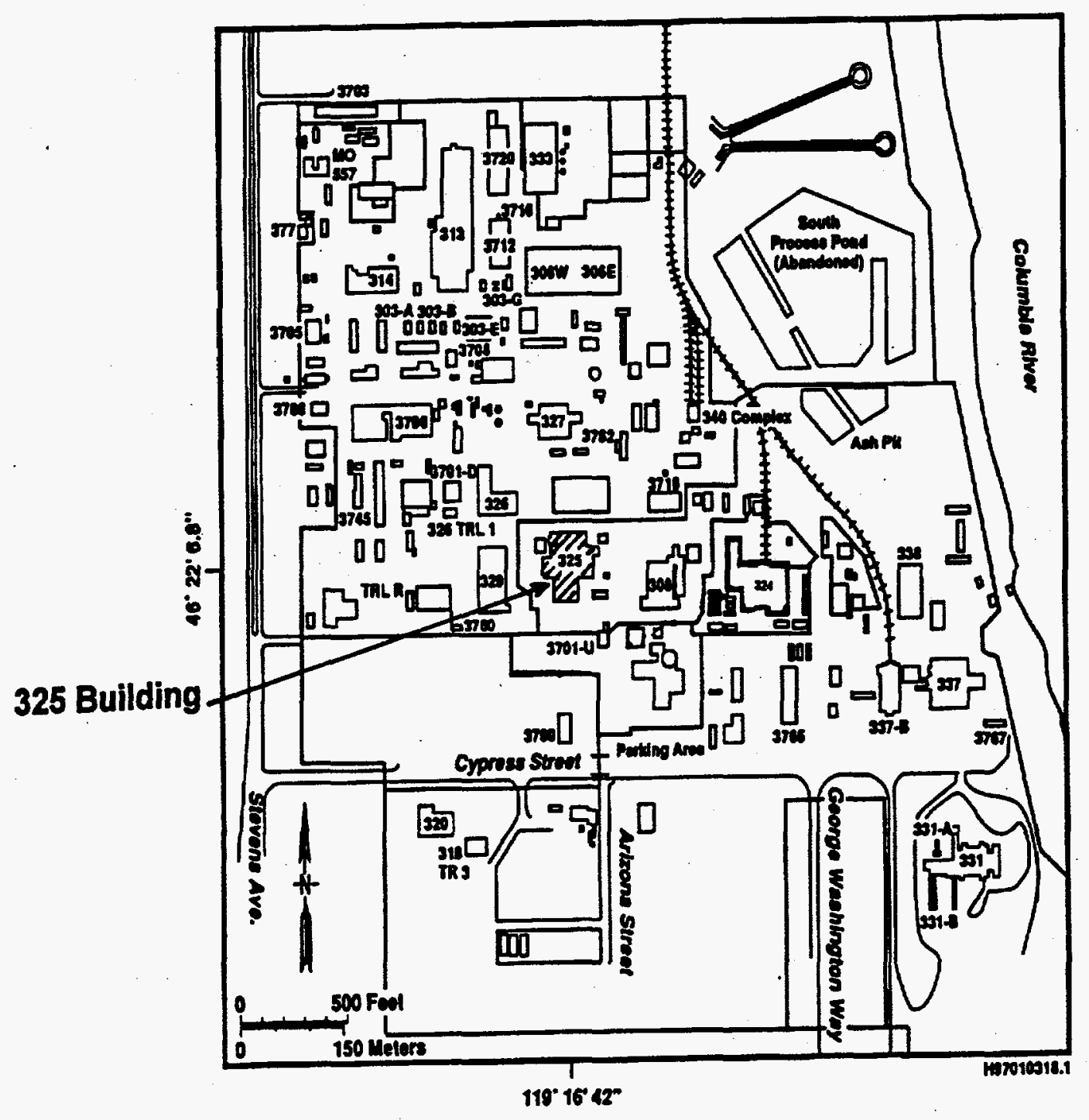

Figure 4.2 300 Area of the Hanford Site 


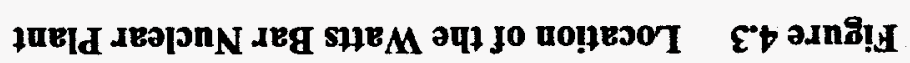
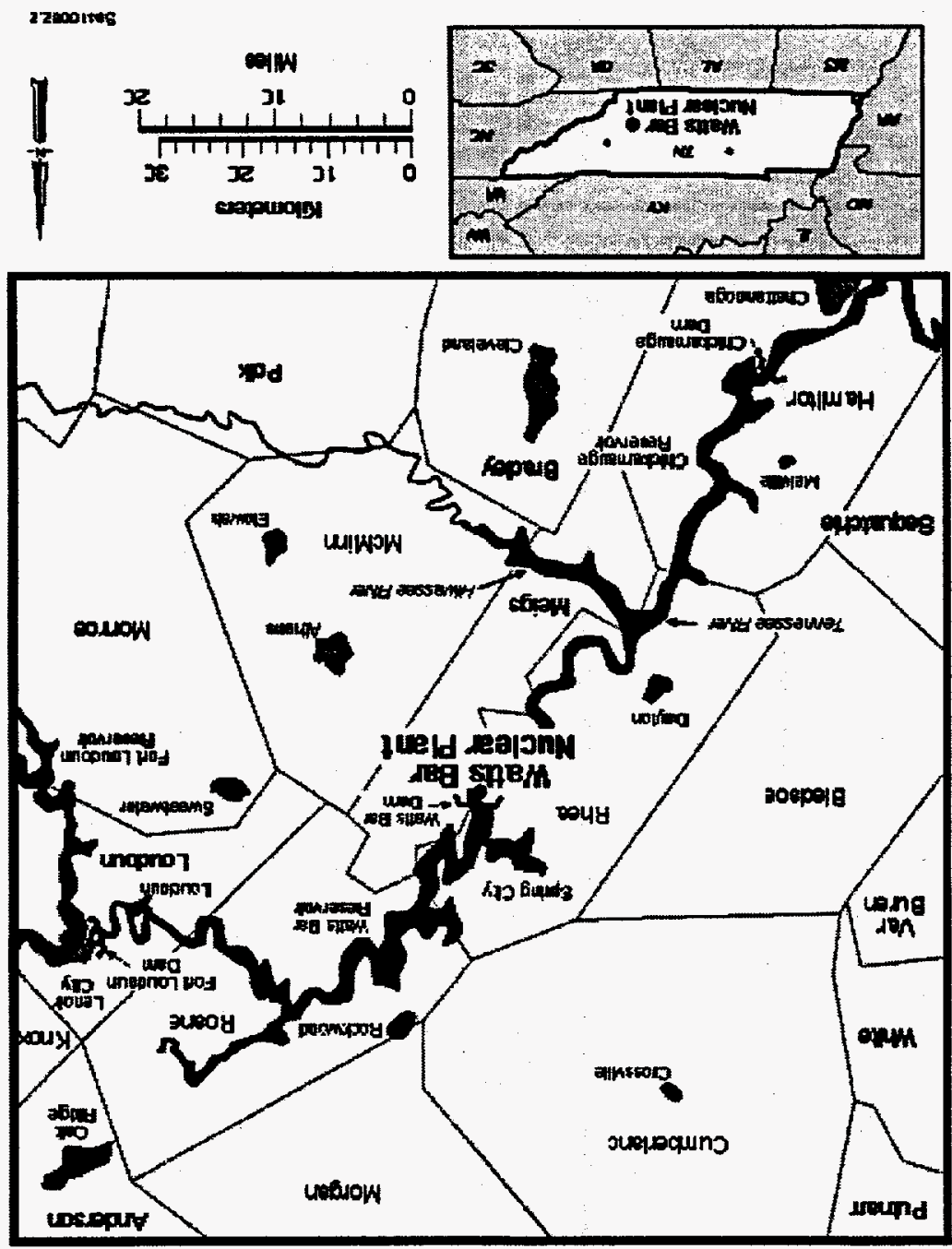


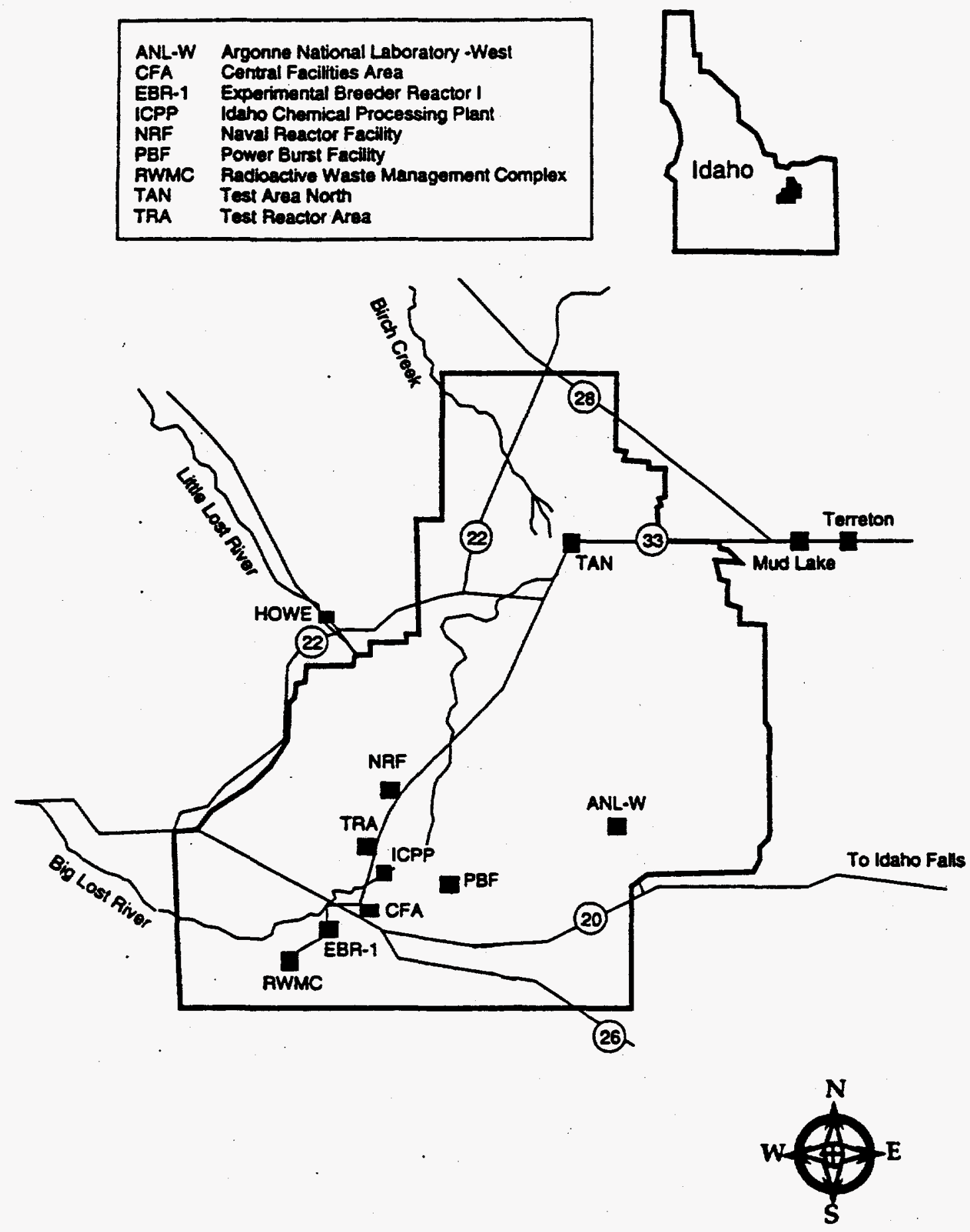

(Not to Scale)

Figure 4.4 Location of Argonne National Laboratory-West 



\subsection{Environmental Impacts of the Proposed Action}

The potential environmental impacts associated with the Proposed Action and alternatives are discussed in this section. Activities associated with the Proposed Action are described in Section 2. Most of these activities would be conducted in conjunction with ongoing operations at each site and would result in minor changes, if any, to the existing impacts of those operations. The impacts of routine operations at the Westinghouse fuel fabrication facility, WBN, and the neutron radiography facility at ANL-W are addressed in this document in the context of cumulative impacts where appropriate.

Consequences associated directly with transporting, irradiating, and examining TPBARs at the identified facilities are discussed in this section. The types of potential impacts evaluated in detail include air quality, water quality, waste disposal, facility accidents, transportation, and health and safety. Impacts in other areas are considered to be minimal and are discussed only as necessary to demonstrate the absence of potential consequences.

\subsection{Air Quality}

The potential consequences of the Proposed Action on radiological and non-radiological air quality at the respective locations where they would occur are discussed in the following sections.

\subsubsection{Atmospheric Emissions of Radionuclides}

Emissions of radionuclides to air from normal operations at DOE facilities are regulated under Subpart $\mathrm{H}$ of the National Emission Standards for Hazardous Air Pollutants (NESHAPs) for radionuclides (40 CFR Part 61). Emissions from commercial nuclear power reactors are regulated under 10 CFR Part 50, and doses to the public are limited to the standards in 10 CFR Part 20. Standards for DOE facilities provide that they may not emit radionuclides to air in quantities that would cause any member of the public to receive a dose greater than 10 mrem $\left(1 \times 10^{-4} \mathrm{~Sv}\right)$ effective dose equivalent (EDE) in any year. Standards in 10 CFR Part 20 for NRC facilities provide that their operations may not result in a dose of greater than $100 \mathrm{mrem} / \mathrm{yr}\left(1 \times 10^{-3} \mathrm{~Sv} / \mathrm{yr}\right)$ to any individual from all pathways. State and local standards for radionuclide emissions to the atmosphere are consistent with federal standards at the locations considered in this EA. All facilities used in the Proposed Action would comply with state and federal regulations.

\subsubsection{Assembly and Incorporation of the TPBAR-LTAs into the Integrated Assemblies}

Incorporation of TPBARs into TPBAR-LTAs at the Westinghouse fuel fabrication facility would not result in radionuclide releases because all materials are nonradioactive prior to irradiation in the reactor. Emissions would not be increased by incorporation of TPBAR-LTAs into the integrated assemblies.

\subsubsection{Irradiation of TPBAR-LTAs, Transportation, and NDE}

Tritium releases from the TPBAR-LTAs during irradiation at WBN are expected to be less than $214 \mathrm{Ci}$ per year to the reactor's primary coolant system because the TPBARs are designed to retain tritium in a solid matrix (Erickson et al 1997). Because most of the tritium that enters the coolant would remain in liquid form, offsite consequences in terms of air quality are not expected. Tritium emissions during transport and NDE of the TPBARs at Hanford and ANL-W are likewise not anticipated because the TPBARs and hardware would be maintained at all times in a shielded environment or sealed within an NRC-licensed Type B transportation cask. 


\subsubsection{Post-Irradiation Examination of TPBARs}

Most of the radionuclide releases that could occur would take place during destructive PIE of the TPBARs at the Hanford Site as they are cut or punctured to determine tritium production levels and to examine their internal structure (see section 2 for a description of the TPBARs). Three major activities associated with PIE have the potential to result in radionuclide releases:

- sectioning of TPBARs to examine their internal structure,

- puncturing and extraction of tritium from TPBARs to determine production and recovery levels, and

- permeability tests of the TPBAR cladding material using a commercial source containing $2000 \mathrm{Ci}$ of tritium.

For this analysis, the range of potential impacts was estimated by assuming that tests are conducted on either the planned number of TPBARs, as noted in Table 5.1, or on all 32 TPBARs as a maximum. The tritium inventory of a single TPBAR was assumed to be $1.2 \mathrm{~g}$ (about $12,000 \mathrm{Ci}$ ), which represents an upper bound based on their design (Erickson et al 1997).

The consequences of the PIE activities with respect to air quality are summarized in Table 5.1; a detailed description of the assumptions for these estimates appears in Appendix C, Section C.2. The maximum total impact of the planned TPBAR post-irradiation examination activities would amount to less than $0.095 \mathrm{mrem} / \mathrm{yr}\left(9.5 \times 10^{-7} \mathrm{~Sv} / \mathrm{y}\right)$ to a maximally exposed member of the public, if all of the activities were conducted within a 1-year period. This represents less than $1 \%$ of the $10 \mathrm{mrem} / \mathrm{yr}\left(1 \times 10^{-4} \mathrm{~Sv} / \mathrm{yr}\right)$ standard for radionuclide emissions from DOE facilities ( 40 CFR Part 61, Subpart $\mathrm{H}$ ). For the maximum case in which all 32 TPBARs are examined, the total would be $0.33 \mathrm{mrem}\left(3.3 \times 10^{-6} \mathrm{~Sv}\right)$, which corresponds to $3.3 \%$ of the standard if all releases occurred within a single year. In reality, these activities would likely be conducted over a longer period, thereby reducing the annual dose to the maximally exposed member of the public.

The dosimetry models incorporated into software used for the analysis assume that tritium is released in the form of water vapor. If any of the estimated releases occur as elemental tritium gas, the dose would be lower than the estimates presented in this section, as discussed in Appendix C, Section C.1. Atmospheric emissions of radionuclides during interim storage or disposal of the TPBAR-LTA hardware and TPBARs are not anticipated. 
Table 5.1 Consequences of Routine Radionuclide Emissions from Post-Irradiation Examination of TPBARs at the Hanford Site 325 Building

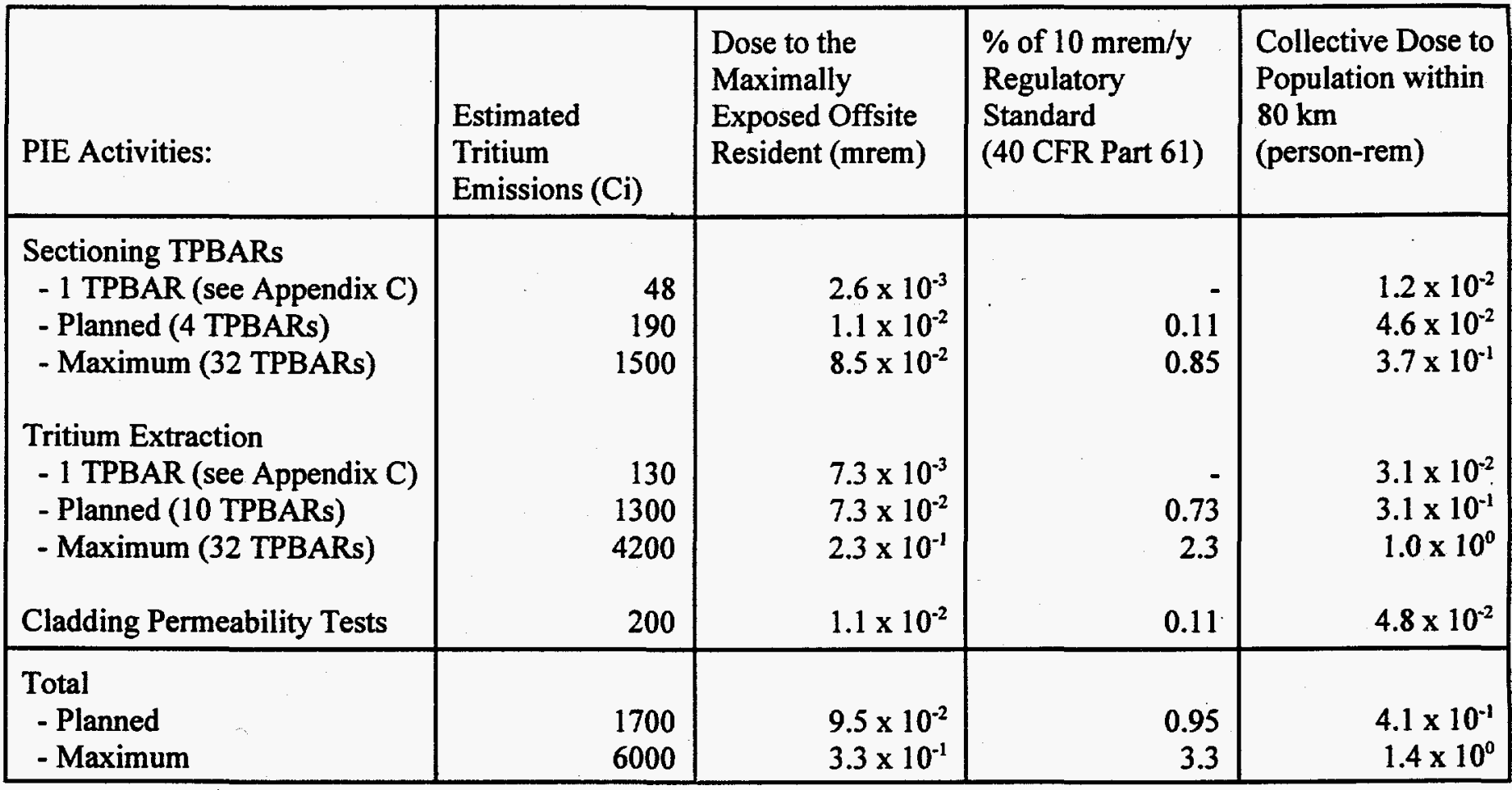

\subsubsection{Atmospheric Emissions of Regulated Nonradioactive Materials}

Emissions of nonradioactive pollutants that are regulated under other provisions of the Clean Air Act are expected to be within regulatory limits, and they would consist largely of combustion products associated with generating primary or auxiliary power, producing process steam, or heating facilities. These emissions occur in conjunction with ongoing operations at each facility and would not increase because of the Proposed Action.

\subsection{Water Quality}

Of the activities considered in the Proposed Action, only irradiation of the TPBAR-LTAs at WBN has the potential to generate liquid effluents that are routinely released to groundwater or surface waters. None of the other activities, including production of the integrated assemblies, neutron radiography, and PIE, are expected to produce liquid effluents (other than the operating effluents typically generated at the facilities) that might affect water quality at the locations where these activities occur. Small quantities of liquid wastes that may be generated in association with these activities would be treated as appropriate and disposed of as described in section 5.3.

During irradiation of the TPBAR-LTAs at WBN, a small quantity of the tritium produced in the TPBARs may be released into the reactor's primary coolant system (up to a maximum of $6.7 \mathrm{Ci} / \mathrm{y}$ per TPBAR, or a total of $214 \mathrm{Ci} / \mathrm{yr}$ ). Exchange of the primary coolant to maintain water chemistry could ultimately release tritiated water to the environment. However, the dose to the maximally exposed offsite individual from the plant's liquid effluents was estimated to be $0.70 \mathrm{mrem} / \mathrm{yr}\left(7.0 \times 10^{-6} \mathrm{~Sv} / \mathrm{yr}\right)$ either with or without the tritium contribution from the TPBARs (Erickson et al 1997). That dose represents about $23 \%$ of the 3 $\mathrm{mrem} / \mathrm{yr}\left(3 \times 10^{-5} \mathrm{~Sv} / \mathrm{yr}\right)$ standard for demonstrating compliance with the requirements of $10 \mathrm{CFR}$ Part 50 , 
Appendix I, and irradiation of the TPBAR-LTAs would not alter the plant's compliance status with respect to the standard. The contribution of tritium from the Proposed Action to the plant's liquid effluents at the point of release to the river would not cause them to exceed the maximum concentration limits established in 10 CFR 20, Appendix $\mathrm{C}\left(1 \times 10^{-3} \mu \mathrm{Ci} / \mathrm{mL}\right)$.

\subsection{Waste}

Wastes generated as a result of the Proposed Action would consist of relatively small quantities of lowlevel radioactive waste, mixed low-level radioactive and hazardous waste, and nonradioactive hazardous waste, in addition to the non-hazardous solid and liquid wastes typically associated with operation of the facilities. No transuranic or high-level radioactive wastes would be produced. Waste minimization practices would be used to reduce, to the extent possible, the quantities of radioactive and hazardous wastes generated at all facilities.

\subsubsection{Assembly and Incorporation of TPBAR-LTAs into the Integrated Assemblies}

Preparation of the integrated assemblies, including incorporation of TPBARs at the Westinghouse fuel fabrication facility, would not produce any radioactive or hazardous wastes in addition to those typically generated at the plant.

\subsubsection{Irradiation of TPBAR-LTAs}

Wastes associated with irradiation of the integrated assemblies at WBN would consist of low-level radioactive liquids and solids generated as the TPBAR-LTAs are removed from the spent fuel pool, decontaminated, and packaged for shipment to Hanford. The quantity of waste generated during this activity is expected to be less than $1 \%$ of the waste generated annually at WBN (i.e., less than $0.4 \mathrm{~m}^{3}$ or 5 $\mathrm{yd}^{3}$ ). These wastes would be treated as appropriate and disposed of at a licensed commercial facility with similar types of wastes from routine reactor operations. The fuel assemblies that initially contained the TPBAR-LTAs would be returned to the reactor core during refueling.

\subsubsection{Post-Irradiation Examination of TPBARs}

Construction at the 325 building to provide an access port into the hot cells could generate radioactive waste in the process of penetrating the hot cell wall. The volume of potentially contaminated materials removed from the wall and associated construction materials is not expected to exceed $1 \mathrm{~m}^{3}\left(1.3 \mathrm{yd}^{3}\right)$ of low-level radioactive waste. Wastes produced during disassembly of the TPBAR-LTAs at Hanford and NDE of the TPBARs at Hanford and ANL-W would consist of laboratory materials and protective clothing used to prevent possible spread of contamination during receipt, handling, and examination. At each facility, the volume of these wastes is expected to be less than $0.1 \mathrm{~m}^{3}\left(0.13 \mathrm{yd}^{3}\right)$ of low-level radioactive waste, which would be disposed of at onsite facilities.

The greatest quantities of low-level radioactive waste, about $20 \mathrm{~m}^{3}\left(26 \mathrm{yd}^{3}\right)$, would be generated during destructive examination of the TPBARs at Hanford. These materials would consist of cuttings and small sections of the rod cladding and tubing, laboratory materials used to control spread of contamination, and either solid molecular sieve or bubbler liquids used to trap the tritium contained in gaseous effluents from the sectioning and extraction processes. Smaller quantities of mixed low-level waste, less than $1 \mathrm{~m}^{3}(1.3$ $\mathrm{yd}^{3}$ ), could be produced during liquid scintillation counting of tritium samples. An estimated $5 \mathrm{~m}^{3}$ ( 6.6 $\mathrm{yd}^{3}$ ) of nonradioactive hazardous wastes would be produced during the laboratory activities as well. Ultimately, decontamination of the hot cells and disposal of unneeded equipment could generate up to 200 $\mathrm{m}^{3}\left(260 \mathrm{yd}^{3}\right)$ of low-level radioactive waste. However, it is anticipated that the laboratory would retain this equipment for an indefinite period to use in future studies following completion of the Proposed Action. 
Prior to disposal, the tritium inventory would remain either in the TPBARs that are not used for PIE tests, or within laboratory wastes consisting of molecular sieve or bubbler trap liquids that retain tritium which has been extracted from the test TPBARs. TPBARs that are not destructively examined would be placed in interim storage in sealed containers until DOE identifies another purpose for them or decides to dispose of them as low level radioactive waste. If the remaining TPBARs are to be disposed of, tritium would be extracted from them and they would be placed in appropriate packaging. The consequences of extracting the tritium would be bounded by the maximum PIE activities as described in section 5.1.1.3. The tritiumdepleted TPBARs would contain less than $5 \%$ of their original tritium inventory in addition to neutron activation products in the structural components. Tritium extracted from the TPBARs that are not subject to PIE could either be disposed as low level radioactive waste, sold to a commercial enterprise, or collected on a tritium storage device for future DOE use.

If all of the TPBARs and hardware from the TPBAR-LTAs are disposed of at Hanford, they would consist of less than $1 \mathrm{~m}^{3}\left(1.3 \mathrm{yd}^{3}\right)$ of solid low-level radioactive waste (exclusive of packaging) in addition to that generated during laboratory activities. All of the radionuclides remaining in the TPBARs and hardware would be bound in solid components, where they would be relatively immobile following disposal. In addition, the TPBARs, hardware and other radioactive laboratory wastes would be appropriately packaged prior to disposal. All radioactive and hazardous wastes generated at Hanford would be disposed of either at the onsite low level radioactive waste burial grounds or in permitted commercial disposal facilities, in accordance with applicable state and federal regulations. Mixed low-level wastes would be stored onsite in permitted facilities.

\subsection{Facility Accidents}

Consequences of potential accidents at facilities that would be involved in the Proposed Action are discussed in this section. These events have been evaluated, or would be evaluated prior to implementing any proposed activities, in sufficient detail to ensure that they would not affect the operational safety basis for those facilities. Operational restrictions and any needed modifications identified as a result of those evaluations would be implemented before work commences to ensure that the facilities remain within their safety guidelines. Accidents during transport of the unirradiated or irradiated TPBARs are addressed in Section 5.5.

\subsubsection{Assembly and Incorporation of TPBAR-LTAs into the Integrated Assemblies}

Because the unirradiated TPBAR-LTAs are non-radioactive and contain no hazardous materials, preparation of the TPBAR-LTAs and integrated assemblies at the Westinghouse fuel fabrication facility would not affect the frequency or consequences of potential accidents associated with that facility.

\subsubsection{Irradiation of TPBAR-LTAs}

Accidents during irradiation of the TPBAR-LTAs at WBN were evaluated to determine whether substituting TPBARs for the standard burnable absorber rods in the reactor's fuel assemblies could affect the frequencies or consequences associated with off-normal events or accidents previously evaluated for the reactor (Erickson et. al 1997). The analysis determined that the presence of TPBAR-LTAs in the reactor core would not be likely to affect the course or severity of such events. This section contains a brief summary of that analysis.

An assumed event, in which the entire tritium inventory from one failed TPBAR might leak into the reactor coolant system over a 1-year period, could increase the offsite dose from the plant's projected liquid effluents from 0.700 to $0.713 \mathrm{mrem} / \mathrm{yr}\left(7.0 \times 10^{-6}\right.$ to $\left.7.13 \times 10^{-6} \mathrm{~Sv} / \mathrm{yr}\right)$. The incremental increase of $0.013 \mathrm{mrem} / \mathrm{yr}\left(1.3 \times 10^{-7} \mathrm{~Sv} / \mathrm{yr}\right)$ to the maximally exposed offsite member of the public would represent 
less than $2 \%$ of the annual dose from the plant's typical liquid effluents, and would be well within the regulatory standards for routine reactor operation. Evaporation of coolant water released into the reactor's fuel handling area following a hypothetical event of this type could increase the tritium concentration in the facility air to about $5.8 \%$ of the derived air concentration limit. Inhalation of tritium by an individual worker who spent 200 hours in the area during refueling operations would result in a cumulative dose of less than $50 \mathrm{mrem}\left(5.0 \times 10^{-4} \mathrm{~Sv}\right)$. Although the likelihood of such an event was not estimated in detail, conditions severe enough to fail the TPBAR cladding are not anticipated during the LTA program.

Evaluation of more severe events indicated that the presence of TPBAR-LTAs in the reactor would also have a minimal impact on their consequences. Releases to the environment following a steam generator tube rupture or steam line break would amount to less than $9 \mathrm{Ci}$ of tritium that could be in the primary coolant due to the presence of the TPBARs. The TPBAR-LTAs would not measurably increase the individual doses resulting from these events, or from other types of events such as a fuel handling accident.

A large break loss of coolant accident could involve conditions severe enough to release up to the entire end-of-cycle tritium inventory from all of the TPBARs to the reactor containment. The estimated offsite dose from this event would be $3.3 \mathrm{rem}(0.033 \mathrm{~Sv})$ to an individual at the exclusion area boundary for 2 hours or $2.0 \mathrm{rem}(0.020 \mathrm{~Sv})$ to an individual in the low population zone over 30 days, either with or without a contribution from the TPBAR-LTAs (Erickson, et. al.1997, values rounded to two significant figures). Therefore, the TPBAR-LTAs would not contribute to the overall risk associated with such an accident. Doses to plant personnel in the reactor control room over a period of 30 days following the event would amount to about $30 \mathrm{mrem}\left(3.0 \times 10^{-4} \mathrm{~Sv}\right)$ from the TPBAR tritium, which is much lower than the contributions from other radionuclides that might be released from the reactor core. The TPBAR-LTAs are also not expected to affect the operation or effectiveness of plant safety systems, such as the emergency core cooling system or the combustible gas control system, during such an event.

\subsubsection{Post-Irradiation Examination of TPBARs}

The consequences of potential accidents during PIE of the TPBARs were evaluated for a spectrum of events having different severities and expected frequencies. A detailed safety analysis of the PIE activities would be performed before work commences; however, the scenarios evaluated for this assessment are representative of the types of events that are typically considered in safety assessments. Three accidents were evaluated for PIE activities, including: 1) breach of a single TPBAR during handling, 2) a localized fire involving the maximum quantity of tritium "at risk" during PIE, and 3) a seismic event and fire, which could involve all 32 TPBARs.

Accidents during PIE at Hanford are expected to bound those for similar types of events at ANL-W because the facilities are farther from the nearest offsite receptors than those at Hanford (greater than $8 \mathrm{~km}$ [ $5 \mathrm{mi}]$ vs $0.58 \mathrm{~km}$ [0.36 mi]). In addition, the localized fire scenario would not apply to NDE activities because the TPBARs would remain intact and therefore would not be considered at risk for that type of accident. Accidents during interim storage and disposal of the TPBARs and hardware would be bounded by the accident consequences for PIE activities and transportation, as discussed in this section and in Section 5.5.

The assumptions for this assessment, as discussed in Appendix C, represent a bounding case for the purposes of preparing this EA and to demonstrate that the consequences of potential accidents are within established safety guidelines. The TPBARs were designed to retain tritium in the solid matrix of the components, even under the relatively severe conditions encountered during irradiation in the reactor. The quantity of free tritium is expected to be a small fraction of the total inventory. Therefore, both a mechanism to damage the TPBAR cladding and an extended period at high temperature would be required to release substantial quantities of tritium from the TPBARs. The probability of an accident that would produce these conditions is not known with accuracy. However, such an event (for example, the severe 
earthquake and fire) is assumed to be credible, although extremely unlikely, for the purposes of this analysis.

An accident involving damage to a single TPBAR with release of the free tritium would result in a dose of $3.5 \mathrm{mrem}\left(3.5 \times 10^{-5} \mathrm{~Sv}\right)$ to an onsite worker, $0.40 \mathrm{mrem}\left(4.0 \times 10^{-6} \mathrm{~Sv}\right)$ to an individual at the Hanford Site boundary, and 1.4 person-rem $(0.014$ person-Sv) to the population within 50 miles $(80 \mathrm{~km})$. That type of event is expected to occur with a frequency between 0.01 and 1.0 per year, or once in 1 to 100 years.

The dose from a localized fire that might release the maximum tritium inventory at risk during PIE (assumed to be $70,000 \mathrm{Ci}$ ) would be $2,500 \mathrm{mrem}(0.025 \mathrm{~Sv})$ to an onsite worker, $290 \mathrm{mrem}\left(2.9 \times 10^{-3} \mathrm{~Sv}\right)$ for an individual at the site boundary, and 1,100 person-rem (11 person-Sv) to the population within 50 miles $(80 \mathrm{~km})$. A bounding localized fire that might result in these consequences was estimated to occur no more than once in 10 years, and the duration of the activity is estimated to be less than 0.5 year. Therefore the combined probability for the release was assumed to be 0.05 . The upper bound frequency of such an event was supported by the fire loss history at Hanford over a 45 -year period, during which time the site experienced 10 fires that resulted in significant property loss. Of those fires, 6 potentially involved radioactive materials, and 2 of the 6 events occurred in laboratory facilities. No fires of that magnitude have occurred in the 325 building since it was occupied in 1953, and they would not be expected to occur routinely in that facility because of the facility design, administrative controls on conduct of operations, and the fire protection program. These mitigating factors, as well as the fact that the maximum "at risk" inventory would not actually be vulnerable during the entire activity, are more difficult to quantify. Therefore, they have not been accounted for in the assumed frequency for the release associated with the localized fire. This analysis is extremely conservative and defines the upper bound of risk associated with this activity. However, administrative controls would be maintained at the 325 building to reduce the risk of potential adverse health effects. Examples of such measures include limitations on the quantity of combustible materials in the work areas, minimizing ignition sources, limiting the inventory at risk, and implementation of fire control measures.

The severe earthquake and fire scenario has an assumed frequency between $10^{-4}$ and $10^{-6}$ per year, or 1 event in 10,000 to 1 million years. If this combination of events occurred, the dose from a hypothetical release of the tritium inventory in all 32 TPBARs (about $385,000 \mathrm{Ci}$ ) would amount to 14,000 mrem $(0.14$ $\mathrm{Sv})$ for the onsite worker $1,600 \mathrm{mrem}(0.016 \mathrm{~Sv})$ to an individual at the site boundary, and 5,800 personrem ( 58 person-Sv) to the population within 50 miles $(80 \mathrm{~km})$.

\subsection{Transportation}

The consequences of transporting both unirradiated and irradiated TPBARs and TPBAR-LTAs are discussed in this section. Both incident-free transport and accidents during transport are addressed. Additional background information and the basis for the results of the analysis presented in the following sections is contained in Appendix D.

\subsubsection{Incident-Free Transportation Impacts}

This section addresses the incident-free transportation impacts associated with the shipments. The transportation impacts include external radiation exposures and the nonradiological impacts due to pollutants emitted by the transport vehicles.

For the analysis, all overland transportation was assumed to be by truck. It was also assumed that one shipment would be required to ship the unirradiated TPBARs to the Westinghouse fuel fabrication facility, and that one shipment of the integrated assemblies would be made from Westinghouse to WBN. Because the unirradiated TPBARs contain no radioactive material, they would not be regulated under the provisions 
of 49 CFR Parts 171-178. Unirradiated integrated assemblies would consist of low specific activity radioactive material, and they would be transported using a commercial carrier authorized to perform such shipments.

An NRC-licensed Type B shipping cask would be used to ship the irradiated TPBAR-LTAs from WBN to Hanford. For the purposes of this analysis, the transport was assumed to require two to four shipments, with either one or two TPBAR-LTAs per shipment. At Hanford, the TPBAR-LTAs would be disassembled and the 32 irradiated TPBARs would be transported in one shipment to a facility such as the HFEF at ANL-W. Following neutron radiography, the TPBARs would be returned to Hanford for additional PIE.

The hardware from the disassembled TPBAR-LTAs would eventually be placed in approved shipping containers and transported from the 325 Building to a Hanford Site solid waste facility for disposal. Following completion of the PIE, the spent TPBARs and other radioactive wastes would also be placed in approved shipping containers and transported from the 325 Building to a Hanford Site solid waste facility for disposal. It is assumed that a total of five shipments would be required to transport the TPBAR-LTA hardware, the TPBARs, and the laboratory wastes.

For this analysis, HIGHWAY 3.3 (Johnson et al. 1993) was used to develop transportation routing information including total distance traveled, en route population densities, and travel distances within three population zones (i.e., rural, suburban, and urban). It was assumed that all shipments of irradiated TPBAR-LTAs and TPBARs (except for those on the Hanford Site) would use "exclusive use" routes and all other shipments would use "commercial" routes. For exclusive use shipments, highway route controlled quantities are shipped on interstate highways or state-designated alternate routes (49 CFR 171-177). This was assumed for shipments of the irradiated TPBAR-LTAs due to the radionuclide inventories and sensitive nature of the shipments (i.e., tritium). Commercial routes are those used for truck shipments of ordinary freight, as designated by local ordinances or other restrictions based only on vehicle size or weight.

\subsubsection{Potential Radiological Impacts}

The radiological impacts associated with incident-free transport of the irradiated TPBAR-LTAs and TPBARs have been analyzed using RADTRAN 4 (Neuhauser and Kanipe 1992). The potential radiological impacts involve in-transit doses to the public or to Hanford Site workers from radiation emitted from the shipping cask and doses to the transport workers in the vicinity of the shipment during cask-handling activities (e.g., moving the cask on or off the truck trailer). In-transit doses have been estimated for the truck drivers and the general public, including persons at truck stops, persons living or working adjacent to the transport route, and nearby travelers (moving in the same and opposite directions).

No radiological impacts are associated with transporting the TPBARs to the Westinghouse fuel fabrication facility or with transporting the integrated assemblies from the Westinghouse fuel fabrication facility to WBN. No radiological impacts are expected to be associated with returning the empty shipping cask to WBN for reloading. Therefore, the routine radiological impacts have been estimated for shipments from WBN to Hanford, from Hanford to ANL-W, from ANL-W back to Hanford, and from the 325 Building to the Hanford Site solid waste facility.

Because of the lack of actual cask exposure rate measurement data, the exposure rate at the surface of the shipping cask was assumed for the purposes of this analysis to be the maximum allowable in 10 CFR 71.51. The total estimated dose to the truck crew for all shipments (WBN to PNNL, PNNL to HFEF, HFEF to PNNL, PNNL to a Hanford Site solid waste facility) would be less than 0.90 person-rem (0.009 person-Sv). The total estimated collective dose to the public along the transportation route for those shipments would be less than 3.4 person-rem ( 0.034 person-Sv). 
The estimated dose to the public for shipments from WBN to PNNL was compared with the estimated dose to the public from natural background radiation along the same transportation route. The comparative evaluation determined that the estimated dose to the public along the transportation route due to natural background radiation would be greater than 13 times the estimated dose to the public for all shipments from WBN to PNNL. (See Appendix D)

\subsubsection{Potential Nonradiological Impacts}

Impacts to the public from nonradiological causes were also evaluated. According to Rao et al. (1982), the types of air pollutants that are generated by transportation and which could affect the public would be sulfur oxides $\left(\mathrm{SO}_{\mathrm{x}}\right)$, particulates, nitrogen oxides $\left(\mathrm{NO}_{\mathrm{x}}\right)$, carbon monoxide $(\mathrm{CO})$, hydrocarbons $(\mathrm{HC})$, and photochemical oxidants $\left(\mathrm{O}_{\mathrm{x}}\right)$. Rao et al. (1982) determined that most health effects are due to $\mathrm{SO}_{\mathrm{x}}$ and particulates.

For all shipments, approximately $210 \mathrm{~km}$ (132 mi) is within the urban population zone; therefore, according to the methodology described in Rao et al. (1982), the number of expected fatalities due to fugitive vehicle emissions is essentially zero (i.e., less than $4.2 \times 10^{-5}$ fatalities for all shipments).

\subsubsection{Transportation Accident Impacts}

This section addresses radiological and nonradiological impacts of accidents during transport. Potential nonradiological accident impacts consist of fatalities resulting from vehicular accidents involving the shipments.

Radiological impacts are calculated for the public as well as for a maximum onsite and offsite individual. The maximum individual doses have been calculated using GENII (Napier et al 1988). The collective impacts to the public are presented in this section as integrated population risks (i.e., accident frequencies multiplied by consequences of all shipments). Population risk calculations were performed using the RADTRAN 4 computer code (Neuhauser and Kanipe 1992).

\subsubsection{Radiological Impacts to the Public from Transportation Accidents}

Potential accident impacts can result from breaches in the shipping cask or damage to the cask shielding. However, the shipping casks are designed, tested, and certified to withstand specified conditions that would not be exceeded in most transportation accidents (i.e., for this analysis, the shipping casks for irradiated TPBAR-LTAs or their components were assumed to meet the Type B packaging requirements specified in 49 CFR Part 173 and 10 CFR Part 71). Therefore, only a small fraction of transportation accidents involve conditions that are severe enough to result in release of radioactive materials.

If radionuclides were released to the environment, they would be dispersed and diluted by weather action; and a small quantity would be deposited on the ground through plume depletion. Access to the area adjacent to the transportation accident would be controlled by emergency response personnel until the area could be remediated and the radiation monitoring personnel had declared the area safe.

The input data used to calculate the radiological dose to the public (i.e., population densities, travel times, and distances) were the same as the inputs used to calculate the incident-free dose to the population. The accident frequency data used in the analysis were based on a review of local or state-specific accident data (Saricks and Kvitek 1994). The Hanford Site accident rates (expressed as accidents $/ \mathrm{km}$ ) used in this analysis were taken from Bergsman et al. (1995) The accident rate used for truck shipments is $8.86 \times 10^{-8}$ accidents $/ \mathrm{km}\left(5.50 \times 10^{-8}\right.$ accidents $\left./ \mathrm{mi}\right)$. The radiological impacts to the public (including non-involved 
Hanford Site workers) associated with truck transportation accidents are estimated to be less than 0.65 person-rem ( 0.0065 person-Sv).

The maximum dose to an individual was calculated for a bounding accident that could occur during shipment of the TPBARs between Hanford and ANL-W. An accident during that portion of the shipments could potentially involve all 32 irradiated TPBARs; any other shipment would involve a smaller number. For accidents outside of DOE facility boundaries, an individual at $100 \mathrm{~m}$ from the release was evaluated. For accidents within DOE facility boundaries, the minimum distance to the Hanford Site boundary from the 325 Building ( $580 \mathrm{~m}$ or $0.36 \mathrm{mi}$ ) was evaluated as a bounding case (distances between ANL-W and the INEEL boundary are substantially greater). Assumptions related to this analysis are detailed in Appendices $C$ and D. The estimated doses for such an event would be 3,100 mrem $(0.031 \mathrm{~Sv})$ to an individual at $100 \mathrm{~m}$, and $160 \mathrm{mrem}(0.0016 \mathrm{~Sv})$ to the offsite receptor at $580 \mathrm{~m}(0.36 \mathrm{mi})$. As noted at the beginning of this section, the NRC-certified Type $B$ casks are designed to prevent release of radioactive materials under conditions encountered in most transportation accidents. The frequency of an event severe enough to result in substantial tritium releases during the round trip between Hanford and ANL-W was estimated to be less than $2 \times 10^{-5}$. Because the TPBARs are designed to retain tritium even under severe conditions, accidents that would involve both extensive mechanical damage and a fire of sufficient duration and intensity to release greater quantities of tritium would be considered incredible (that is, they would have an estimated frequency lower than $1 \times 10^{-7}$, or 1 in 10 million).

\subsubsection{Nonradiological Impacts to the Public from Transportation Accidents}

Potential nonradiological accident impacts consist of fatalities resulting from vehicular accidents involving the shipments. The fatalities are due to vehicle crashes with solid objects, rollovers, or collisions. Impacts to the public, i.e. individuals on or immediately adjacent to roadways, have been estimated using unit risk factors (i.e., fatalities per kilometer). It is assumed that a vehicle accident that would result in a release from a shipping cask would also result in crew fatalities; therefore, nonradiological vehicular accident impacts are calculated for the public only. No impacts to the public are associated with the transport of the unirradiated and irradiated TPBARs, TPBAR-LTAs, and integrated assemblies (i.e., less than $6.1 \times 10^{-4}$ acute fatalities).

\subsection{Health and Safety}

The consequences of the Proposed Action in terms of health and safety are discussed in this section, and are based in part on the potential impacts identified in sections 5.1 through 5.5. The methods used to estimate health consequences are described in section 5.6.1. The expected nature and magnitude of the consequences for workers and for the public are discussed in sections 5.6.2 and 5.6.3, and a summary of the health consequences appears in section 5.6.4.

\subsubsection{Basis for Health and Safety Consequences}

The methods used to estimate health consequences of the Proposed Action are discussed in the following sections. Given the nature of the Proposed Action, the potential health consequences include those that might result from radionuclide emissions during irradiation and laboratory examination of the TPBARs, direct radiological exposures to workers and the public from transportation or laboratory activities, and potential radiological and nonradiological accidents associated with transportation and laboratory activities.

\subsubsection{Basis for Radiological Health Consequences}

Estimates of consequences from radiological exposures to workers and the public are based on recommendations of the International Commission on Radiological Protection (ICRP 1991). The 
consequences in terms of latent cancer fatalities and total detrimental health effects are presented in Table 5.2 for both adult workers and the general population. The total incidence of detrimental health effects includes both fatal and nonfatal cancers and severe hereditary effects. The higher rates for health effects in the general population account for the presence of more sensitive individuals, such as children, compared with the relatively homogeneous population of healthy adults in the work force.

Table 5.2 Summary of Basis for Health Consequences from Radiological Exposures (from ICRP 1991)

\begin{tabular}{|c|c|c|}
\hline Type of Effect & Effects per Unit Radiation Dose" & Radiation Dose to Produce 1 Effect \\
\hline $\begin{array}{l}\text { Latent Cancer Fatality } \\
\text { Adult Workers } \\
\text { General Population }\end{array}$ & $\begin{array}{l}4 \times 10^{-4} / \text { person-rem } \\
5 \times 10^{-4} / \text { person-rem }\end{array}$ & $\begin{array}{l}2500 \text { person-rem } \\
2000 \text { person-rem }\end{array}$ \\
\hline $\begin{array}{l}\text { Total Detriment } \\
\text { Adult Workers } \\
\text { General Population }\end{array}$ & $\begin{array}{l}5.6 \times 10^{-4} / \text { person-rem } \\
7.3 \times 10^{-4} / \text { person-rem }\end{array}$ & $\begin{array}{l}1800 \text { person-rem } \\
1400 \text { person-rem }\end{array}$ \\
\hline \multicolumn{3}{|c|}{$\begin{array}{l}\text { These estimates include a reduction factor of } 2 \text { to account for the lower risk of low dose, low dose } \\
\text { rate exposures as discussed in ICRP (1991). To convert person-rem to person-Sv, multiply by } 0.01 \text {. } \\
\text { b Total Detriment includes fatal and nonfatal cancers and severe hereditary effects. }\end{array}$} \\
\hline
\end{tabular}

The ICRP estimates are based on radiation exposures to populations at higher doses and dose rates, and by different pathways, than those normally encountered in the environment. As a result, the health effects coefficients in Table 5.2 are presented in terms of collective dose to a relatively large population. Collective dose is defined as the sum of doses to all individuals in the population, who may exhibit a wide range of susceptibility to radiation-induced health effects. The health effects coefficients are therefore associated with substantial uncertainty when applied to dose estimates for individuals, whose sensitivity may differ from the population average. However, the assumptions used to develop the health effects coefficients are sufficiently conservative that they would be "unlikely to underestimate the risks" (ICRP 1991).

Risk, as defined for this analysis, refers to the potential health consequences of an activity to a population or an individual weighted by the frequency with which that activity or event is expected to occur. Estimates of the latent cancer fatality (LCF) risk associated with routine operations assume that the consequences would occur; that is, the events that produce the dose to an individual or population have an expected frequency of 1.0. In the case of accidents, the risk of LCF incorporates the expected frequency of the event that produces a potential dose. Therefore, the risk for radiological accidents is numerically equal to the hypothetical dose to an individual or population (if the event occurs) multiplied by the health effects coefficient and the estimated event frequency. Risks for accidents are reported per year of operation where the exact duration of the proposed action is not known.

\subsubsection{Basis for Nonradiological Health Consequences}

Consequences to workers and the public from exposure to hazardous process chemicals were not evaluated in detail for the Proposed Action because the activities that would be conducted do not require sufficient quantities of such materials to present a substantial risk. Nonradiological risks from incident-free transportation are based on human health impacts from vehicular emissions, and those from transportation accidents are based on traffic statistics specific for the states and population densities along the proposed transportation routes as described in Section 5.5. 
Nonradiological risks to workers from occupational illness or injury are based on statistics for DOE and DOE contractor experience (DOE 1996). The average "total recordable case rate" for the years 1990-1994 was 4.1 per 200,000 worker hours. Using the standard assumption for DOE and contractors of 1830 hours per year for a full-time-equivalent worker (FTE), the average total recordable case rate amounts to about 0.038 per FTE, or about 1 for every 27 FTEs. The rates were somewhat higher for construction activities, which accounted for about $18 \%$ of the reportable cases and about $10 \%$ of the work force in 1995 (or about 1 case per 15 FTEs). Total recordable cases include all work-related deaths, illnesses, and injuries that impair worker performance or require medical treatment beyond first aid. Of DOE's total recordable cases in $1995,0.06 \%$ were fatalities, $45 \%$ were lost workday cases, and slightly less than $55 \%$ were nonfatal cases without lost work time.

\subsubsection{Worker Health and Safety Consequences of the Proposed Action}

Radiological doses to workers during activities associated with the Proposed Action would not be expected to change substantially compared with those that the involved workers would typically receive during the course of their activities at all facilities. All of the proposed activities would be conducted to maintain worker radiation doses "as low as reasonably achievable" (ALARA).

Preparation of integrated assemblies at the Westinghouse fuel fabrication facility could be associated with radiological exposure to workers, but the exposures would be the same as those for production of standard fuel assemblies and would not increase measurably for assemblies containing the TPBARs.

During refueling, workers at WBN would handle the integrated assemblies and TPBAR-LTAs in a manner similar to standard fuel and absorber assemblies and would not likely receive an increased dose from that activity. Tritium released from TPBARs to the reactor coolant during irradiation may result in exposure to workers during refueling (Erickson et al 1997); however, the doses from evaporation of cooling water in the area around the spent fuel pool are expected to amount to less than 2 mrem $\left(2 \times 10^{-5} \mathrm{~Sv}\right)$. The risk of LCF associated with that incremental dose is less than $8 \times 10^{-7}$. Preparing the TPBAR-LTAs for return shipment to Hanford may involve some worker exposures, but these are not expected to increase the total exposure workers receive during the course of their typical activities at the plant. Transportation workers are expected to accumulate a collective dose of less than 0.9 person-rem ( 0.009 person-Sv) during shipments associated with the Proposed Action (see Section 5.5.1.1).

Worker exposures during PIE activities are likely to be the largest source of occupational dose associated with the Proposed Action, although this work would take place in shielded facilities designed to provide protection from high-activity radionuclide sources. Radiological doses to DOE workers are limited to 5 $\mathrm{rem} / \mathrm{yr}(0.05 \mathrm{~Sv} / \mathrm{yr}) \mathrm{EDE}$ by standards in $10 \mathrm{CFR}$ Part 835, and in practice they are typically controlled to $0.5 \mathrm{rem} / \mathrm{yr}(0.005 \mathrm{~Sv} / \mathrm{yr})$ by site-specific administrative procedures unless special justification and approval are obtained. During 1995, the collective dose to workers in the 325 Building laboratories, including the shielded facilities, was about 10 person-rem ( 0.10 person-Sv), or an average of $0.1 \mathrm{rem} / \mathrm{y}(0.001 \mathrm{~Sv} / \mathrm{yr})$ for the 100 workers employed in the facility. The 325 Building average worker dose was similar to the Hanford Site average for workers with a measurable (i.e., non-zero) dose during 1995, which was 0.12 rem (0.0012 Sv). Assuming that the 6-8 workers performing PIE experience similar radiological doses, their collective dose would be less than 1 person-rem/yr ( 0.01 person-Sv/yr). The collective radiological doses to workers during neutron radiography and those resulting from construction of the hot cell access port are also expected to be less than 1 person-rem.

The total collective dose to all workers directly associated with the Proposed Action (including transportation, irradiation, construction, and PIE) is estimated to amount to less than 3 person-rem $(0.03$ person-Sv). Therefore the maximum LCF risk for involved workers would be about 0.001 , or 1 in 800 , and the total collective dose is well below the 1800 person-rem (18 person-Sv) that might result in longterm health effects in a worker population. Exposures to noninvolved (co-located) workers could result 
from air emissions during PIE activities, but the collective doses would be much smaller than those for directly involved workers. The individual doses to a co-located worker would typically be lower than that estimated for an offsite resident. As a result, these exposures are not likely to contribute to the overall risk associated with the Proposed Action.

The risk to an individual onsite worker from radiological accidents evaluated for WBN and the PIE laboratories, as described in section 5.4, is lower than 1 in 10,000. The risks associated with specific events are listed in Section 5.6.4, Table 5.3.

Transportation accident statistics are based on total fatality rates per mile traveled over the likely transport routes. Therefore, the risk of fatality among transportation workers from vehicle accidents during shipments associated with the Proposed Action would be bounded by the risk estimated for members of the public in section 5.5.2.2 (6 $\times 10^{-4}$ or 1 in 1600$)$.

The risk of occupational injury or illness to facility workers is based on the labor requirements for the Proposed Action and recordable case rates for DOE contractors. The labor requirements for PIE are estimated at about 20 FTEs, of which about 5 FTEs would be involved in construction activities. Other activities associated with the Proposed Action are not expected to increase labor needs relative to current employment at the participating facilities. The labor requirements for the Proposed Action are below the DOE average 27 FTEs overall or 15 FTEs for construction that correspond to one recordable case of occupational injury or illness. Therefore, at most, one recordable case might occur during the project activities, and it is most likely to be a relatively minor event that does not result in lost work time.

\subsubsection{Public Health and Safety Consequences of the Proposed Action}

Government agencies have increasingly attempted to enact regulations governing use and emissions of potentially hazardous materials in which the standards are based on risk to members of the public. For radiological exposures, the maximum regulatory limits established by these agencies generally correspond to a risk of LCF on the order of 1 in 10,000 to 1 in 1,000,000 for an "average" member of the population. Therefore, activities that operate within these limits would result in risks that are no greater than those associated with the risk-based standards. The DOE regulatory standard of $100 \mathrm{mrem} / \mathrm{yr}(0.001 \mathrm{~Sv} / \mathrm{yr})$ maximum dose to a member of the public from normal operations results in an estimated risk of LCF equal to about 1 in 20,000 . The more restrictive $10 \mathrm{mrem} / \mathrm{yr}\left(1 \times 10^{-4} \mathrm{~Sv} / \mathrm{yr}\right)$ EPA standard for air emissions corresponds to a maximum individual risk of 1 in 200,000 , whereas the $3 \mathrm{mrem} / \mathrm{yr}\left(3 \times 10^{-5} \mathrm{~Sv} / \mathrm{yr}\right) \mathrm{NRC}$ ALARA standard for liquid effluents represents an individual risk of 1 in 670,000 .

The radiological consequences of the Proposed Action under normal operating conditions, as discussed in sections 5.1 and 5.2, are lower than the limits specified in applicable regulatory standards. The individual risk of LCF associated with the $0.095 \mathrm{mrem}\left(9.5 \times 10^{-7} \mathrm{~Sv}\right)$ dose from planned PIE activities (section 5.1) amounts to less than $5 \times 10^{-8}$, or 1 in 20 million. Irradiation of the TPBAR-LTAs at WBN would not be expected to increase the LCF risk to a maximally exposed member of the public (sections 5.1 and 5.2). The 3.4 person-rem ( 0.034 person-Sv) from incident-free transportation results in collective risks of LCF that are less than $\mathbf{0 . 0 0 2}$, or 1 in 600 , for the entire population along the transportation routes (section 5.5).

Public consequences from potential radiological accidents at facilities, as discussed in section 5.4, result in risks to individual members of the public that are less than $1 \times 10^{-5}$, or 1 in 100,000 , and collective risks that are less than $3 \times 10^{-2}$ to the population within 50 miles $(80 \mathrm{~km})$. The risks associated with specific types of events are listed in Section 5.6.4, Table 5.3. The collective risk of LCF to the population from radiological accidents along transportation routes (Section 5.5.2.1) amounts to $3 \times 10^{-4}$, or less than 1 in 3000. The individual radiological risk from a bounding credible accident during transportation (Section 5.5.2.1) would be less than $3 \times 10^{-8}$, or 1 in 30 million. 
Nonradiological health consequences for the public largely result from transportation of both unirradiated and irradiated TPBAR assemblies between the facilities participating in the Proposed Action. The collective risk of fatality associated with vehicle emissions during incident-free transport amounts to less than 1 in 24,000 for the population along shipping routes (Section 5.5.1.2). The risk of fatality from vehicle accidents would be about 1 in 1600 for the same population (Section 5.5.2.2).

\subsubsection{Summary of Health and Safety Consequences of the Proposed Action}

Table 5.3 contains a summary of the potential health and safety consequences of the Proposed Action, as described in sections 5.1 through 5.6.3.

Table 5.3 Summary of Health and Safety Consequences of Proposed Action

\begin{tabular}{|c|c|c|c|}
\hline Activity or Event & $\begin{array}{l}\text { Units of } \\
\text { Measure }\end{array}$ & $\begin{array}{l}\text { Consequences/Risk } \\
\text { of Activity or } \\
\text { Event }^{\mathbf{a}}\end{array}$ & $\begin{array}{l}\text { Estimated } \\
\text { Frequency }\left(\mathrm{yr}^{-1}\right) \\
\text { or Probability of } \\
\text { Event }\end{array}$ \\
\hline $\begin{array}{l}\text { Air Emissions (Section 5.1) } \\
\text { - Planned PIE } \\
\text { Offsite Individual Dose } \\
\text { Offsite Individual Risk } \\
\text { Offsite Collective Dose } \\
\text { Offsite Collective Risk } \\
\text { - Maximum PIE } \\
\text { Offsite Individual Dose } \\
\text { Offsite Individual Risk } \\
\text { Offsite Collective Dose } \\
\text { Offsite Collective Risk }\end{array}$ & $\begin{array}{l}\text { mrem } \\
\text { LCF } \\
\text { person-rem } \\
\text { LCF } \\
\text { mrem } \\
\text { LCF } \\
\text { person-rem } \\
\text { LCF }\end{array}$ & $\begin{array}{l}9.5 \times 10^{-2} \\
5 \times 10^{-8} \\
4.1 \times 10^{-1} \\
2 \times 10^{-4} \\
3.3 \times 10^{-1} \\
2 \times 10^{-7} \\
1.4 \times 10^{0} \\
7 \times 10^{-4}\end{array}$ & 1.0 \\
\hline
\end{tabular}




\begin{tabular}{|c|c|c|c|}
\hline Activity or Event & $\begin{array}{l}\text { Units of } \\
\text { Measure }\end{array}$ & $\begin{array}{l}\text { Consequences/Risk } \\
\text { of Activity or } \\
\text { Event }^{\mathrm{a}}\end{array}$ & $\begin{array}{l}\text { Estimated } \\
\text { Frequency }\left(\mathrm{yr}^{-1}\right) \\
\text { or Probability of } \\
\text { Event }\end{array}$ \\
\hline Transportation (Section 5.5) & & & \\
\hline $\begin{array}{l}\text { - Incident-Free Transport (Section 5.5.1) } \\
\text { Collective Dose to Crew } \\
\text { Collective Risk to Crew }\end{array}$ & $\begin{array}{l}\text { person-rem } \\
\text { LCF }\end{array}$ & $\begin{array}{l}9.0 \times 10^{-1} \\
4 \times 10^{-4}\end{array}$ & 1.0 \\
\hline $\begin{array}{l}\text { Collective Dose to Public } \\
\text { Collective Risk to Public }\end{array}$ & $\begin{array}{l}\text { person-rem } \\
\text { LCF }\end{array}$ & $\begin{array}{l}3.4 \times 10^{0} \\
2 \times 10^{-3}\end{array}$ & \\
\hline $\begin{array}{l}\text { Non-radiological Public Risk } \\
\text { (Vehicle Emissions) }\end{array}$ & $\begin{array}{l}\text { Fatality } \\
\text { (all causes) }\end{array}$ & $4 \times 10^{-5}$ & \\
\hline $\begin{array}{l}\text { - Transportation Accidents (Section 5.5.2) } \\
\text { Collective Dose to Public } \\
\text { Collective Risk to Public }\end{array}$ & $\begin{array}{l}\text { person-rem } \\
\text { LCF }\end{array}$ & $\begin{array}{l}6.5 \times 10^{-1} \mathrm{c} \\
3 \times 10^{-4}\end{array}$ & c \\
\hline $\begin{array}{l}\text { 100-m Individual Dose } \\
\text { Individual Worker Risk } \\
\text { Individual Public Risk }\end{array}$ & $\begin{array}{l}\text { mrem } \\
\text { LCF } \\
\text { LCF }\end{array}$ & $\begin{array}{l}3.1 \times 10^{3} \\
<2 \times 10^{-8} \\
<3 \times 10^{-8}\end{array}$ & $<2 \times 10^{-5}$ \\
\hline $\begin{array}{l}\text { Offsite Individual Dose } \\
\text { Offsite Individual Risk }\end{array}$ & $\begin{array}{l}\text { mrem } \\
\text { LCF }\end{array}$ & $\begin{array}{l}1.6 \times 10^{2} \\
<2 \times 10^{-9}\end{array}$ & $<2 \times 10^{-5}$ \\
\hline $\begin{array}{l}\text { Non-radiological Public Risk } \\
\text { (Transportation Accidents) }\end{array}$ & $\begin{array}{l}\text { Acute } \\
\text { Fatality }\end{array}$ & $6 \times 10^{-4}$ & d \\
\hline
\end{tabular}




\begin{tabular}{|c|c|c|c|}
\hline Activity or Event & $\begin{array}{l}\text { Units of } \\
\text { Measure }\end{array}$ & $\begin{array}{l}\text { Consequences/Risk } \\
\text { of Activity or } \\
\text { Event }^{\mathrm{a}}\end{array}$ & $\begin{array}{l}\text { Estimated } \\
\text { Frequency }\left(\mathrm{yr}^{-1}\right) \\
\text { or Probability of } \\
\text { Event }\end{array}$ \\
\hline \multicolumn{4}{|l|}{ Facility Accidents (Section 5.4) } \\
\hline - Irradiation - TPBAR Breach & & & \multirow[t]{5}{*}{$\mathbf{b}$} \\
\hline Onsite Individual Dose & mrem & $<5.0 \times 10^{1}$ & \\
\hline Onsite Individual Risk & LCF & $<2 \times 10^{-5}$ & \\
\hline Offsite Individual Dose & mrem & $1.3 \times 10^{-2}$ & \\
\hline Offsite Individual Risk & LCF & $<6 \times 10^{-9}$ & \\
\hline - PIE - TPBAR Breach & & & \multirow[t]{7}{*}{$1 \times 10^{-2}$ to 1.0} \\
\hline Onsite Individual Dose & mrem & $3.5 \times 10^{0}$ & \\
\hline Onsite Individual Risk & LCF & $<1 \times 10^{-6}$ & \\
\hline Offsite Individual Dose & mrem & $4.0 \times 10^{-1}$ & \\
\hline Offsite Individual Risk & LCF & $<2 \times 10^{-7}$ & \\
\hline Offsite Collective Dose & person-rem & $1.4 \times 10^{0}$ & \\
\hline Offsite Collective Risk & LCF & $<7 \times 10^{-4}$ & \\
\hline - PIE - Localized Fire & & & \multirow[t]{7}{*}{$<5 \times 10^{-2}$} \\
\hline Onsite Individual Dose & mrem & $2.5 \times 10^{3}$ & \\
\hline Onsite Individual Risk & LCF & $<1 \times 10^{-4}$ & \\
\hline Offsite Individual Dose & mrem & $2.9 \times 10^{2}$ & \\
\hline Offsite Individual Risk & LCF & $<1 \times 10^{-5}$ & \\
\hline Offsite Collective Dose & person-rem & $1.1 \times 10^{3}$ & \\
\hline Offsite Collective Risk & LCF & $<3 \times 10^{-2}$ & \\
\hline - PIE - Severe Earthquake + Fire & & & \multirow[t]{7}{*}{$1 \times 10^{-6}$ to $1 \times 10^{-4}$} \\
\hline Onsite Individual Dose & mrem & $1.4 \times 10^{4}$ & \\
\hline Onsite Individual Risk & LCF & $<6 \times 10^{-7}$ & \\
\hline Offsite Individual Dose & mrem & $1.6 \times 10^{3}$ & \\
\hline Offsite Individual Risk & LCF & $<8 \times 10^{-8}$ & \\
\hline Offsite Collective Dose & person-rem & $5.8 \times 10^{3}$ & \\
\hline Offsite Collective Risk & LCF & $<3 \times 10^{-4}$ & \\
\hline
\end{tabular}




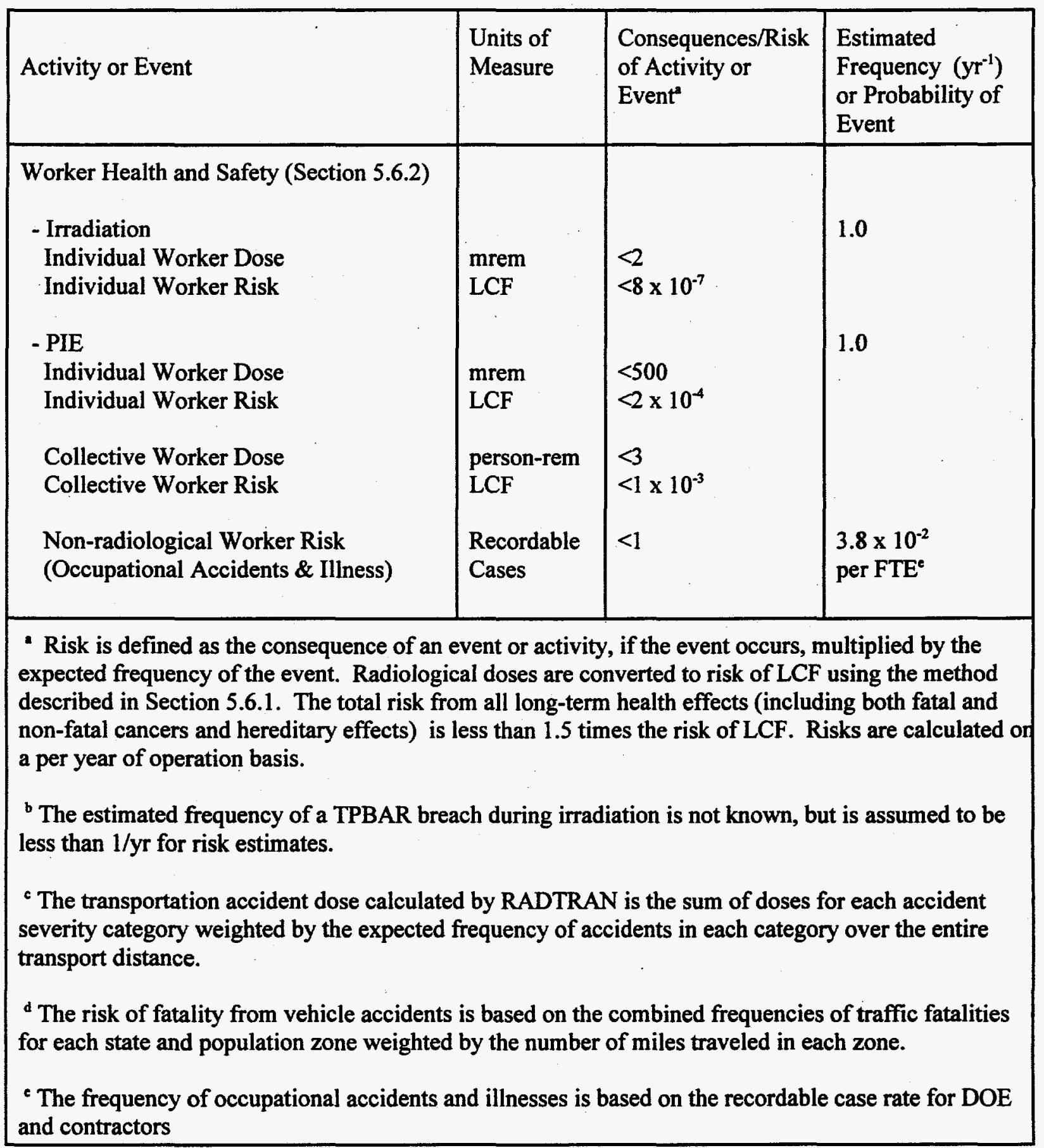

\subsection{Other Environmental Impacts}

The types of environmental impacts for which the Proposed Action is expected to have minimal, if any, consequences are discussed in this section. The types of impacts in this category include those on land use, socioeconomics, cultural resources, aesthetic and scenic resources, geologic resources, ecological resources, noise, and site services. 


\subsubsection{Land Use}

No new facilities would be constructed for the Proposed Action at any of the locations involved. Only minor modifications would be made to the Hanford Site 325 Building to accommodate transfer of the TPBARs and TPBAR-LTAs into the hot cells. The modifications would not affect present or future land use in the surrounding area.

\subsubsection{Socioeconomics}

The number of employees participating in the Proposed Action would be relatively small and would utilize existing staff at all of the facilities involved. Therefore, impacts on the local economy or community infrastructure at these locations would be negligible.

\subsubsection{Cultural Resources}

The Proposed Action would not involve excavation in previously undeveloped areas of the participating sites. Therefore, the opportunity to discover artifacts that might be of cultural or archeological significance is very low. If items of potential significance were discovered, work at the site would be suspended; and the disposition of the find would be determined in consultation with representatives of appropriate cultural groups and regulatory agencies.

The Hanford Site 325 Building played an important role in its association with nationally significant Cold War era activities such as pioneering programs in chemical separations, waste management and vitrification, and other radiochemistry projects. Thus, DOE has concluded that Building 325 is eligible for inclusion in the National Register of Historic Places under criterion A as a contributing property within the Hanford Site Manhattan Project and Cold War Historic District.

In the Programmatic Agreement among the U.S. Department of Energy Richland Operations Office, the Advisory Council on Historic Preservation, and the Washington State Historic Preservation Office for the Maintenance, Deactivation, Alteration, and Demolition of the Built Environment on the Hanford Site, Washington, Building 325 is listed as a contributing property to the historic district and is recommended for mitigation under the Sitewide Treatment Plan. Any modifications to this facility included in the Proposed Action would be performed in accordance with the National Historic Preservation Act and guidance from the state historic preservation officer to preserve information that might be of historic value.

\subsubsection{Aesthetic and Scenic Resources}

None of the proposed activities would require extensive construction of facilities or infrastructure that might impact scenic resources, nor would they result in air emissions that could affect visibility. The program would, therefore, have no effects on aesthetic or scenic resources.

\subsubsection{Geologic Resources}

The Proposed Action would not require use of scarce geologic resources for which there are competing uses, nor would they involve activities that might make valuable resources unavailable for other uses.

\subsubsection{Ecological Resources}

The Proposed Action would not require construction of new facilities or infrastructure at any of the participating sites, except for minor modifications to the Hanford Site 325 Building, as discussed previously. No areas designated as flood plains, wetlands, or other sensitive natural habitats would be affected by the Proposed Action. Therefore, the potential impact on ecological resources is minimal. 
A biological survey of the 325 Building vicinity was conducted on May 21, 1996 (See Appendix B). The area has been previously disturbed and exhibits characteristics typical of disturbed areas. The surrounding substrate consists primarily of packed gravel and pavement, supporting sparse amounts of cheat grass (Bromos tectorum) and Russian thistle (Salsola kali). No migratory birds were observed in the project area. The minimal activity that would be involved in any modifications to the 325 Building during the proposed activities, along with the absence of unique or sensitive ecological resources in this developed area of the Hanford Site, makes any substantial consequences to plant or animal populations unlikely.

\subsubsection{Noise}

The Proposed Action would not generate large volumes of traffic at any of the participating sites, nor would they involve noise-generating equipment other than that associated with normal operation of the facilities. Therefore the program would not result in an increased noise level at any location.

\subsubsection{Site Services}

The Proposed Action would not involve activities that require large quantities of power, process heat, fossil fuels, or water. Therefore, use of site services at any of the participating facilities would not be expected to change substantially as a result of the Proposed Action.

\subsection{Environmental Justice}

Impacts of the Proposed Action on ethnic or low-income groups in the surrounding area were considered in this assessment. An evaluation of environmental justice impacts of proposed federal actions, as required by Executive Order 12898, must consider a range of factors that may place disproportionate adverse environmental impacts on minority and low-income populations. Although the executive order does not directly apply to the TVA, that agency typically includes an evaluation of potential impacts on low income and minority populations in conducting its NEPA reviews. Environmental justice impacts from the Proposed Action considered in this EA are not expected to result in either disproportionate adverse human health risks from exposure to radiation or hazardous chemicals or disproportionate adverse socioeconomic impacts to minority or low-income segments of the community.

Compared with the average for the State of Tennessee, WBN is located in a predominately non-minority, low-income area (NRC 1995). Although nearby low-income residents would experience greater exposure to facility effluents, the operational impacts of the Proposed Action are not expected to result in health consequences to even the most exposed individuals (See sections 5.1 through 5.6). Therefore, the surrounding populations would not be expected to suffer adverse and disproportionate consequences as a result of the plant's routine operation or of the Proposed Action considered in this EA. Minority population centers are generally at a greater distance from the facility, therefore it is unlikely that they would be disproportionately affected by the Proposed Action, whether adverse or beneficial.

Minority populations and low-income populations are present in some locations near the Hanford Site. However, the demographic composition in the areas that would receive the greatest exposure to routine effluents from the 325 Building activities (east and south of the 300 Area) are generally comparable to those of the surrounding counties and the State of Washington. (Neitzel 1996). The Proposed Action is not expected to have substantial impacts in terms of routine radiological or hazardous effluents; therefore, there would be no opportunity for disproportionate and adverse impacts on minority or low-income groups in the surrounding population.

Accidental radionuclide emissions during irradiation of TPBAR-LTAs at WBN, neutron radiography of the TPBARs at ANL-W, or PIE activities at Hanford could disproportionately affect minority or low- 
income populations adjacent to those facilities, depending on atmospheric conditions prevailing at the time of the event. However, the consequences of those events, other than the extremely low-frequency accidents, are generally within the regulatory standards for routine operations. The probability that such events would have disproportionate adverse impacts on minority or low-income populations is therefore very low, and is not expected to differ from the likelihood of potential impacts on other segments of the population.

\subsection{Cumulative Impacts}

Cumulative impacts of the Proposed Action and other anticipated or ongoing actions are estimated for those categories of environmental effects where the Proposed Action might represent an identifiable increase compared with current or future activities. Cumulative impacts are not discussed for the types of consequences that would not change substantially as a result of the Proposed Action. The types of impacts for which cumulative effects could occur include emissions to air or water, waste, transportation, and health and safety of workers and the public.

\subsubsection{Cumulative Impacts on Air Quality}

The only emissions that could have a cumulative effect on air quality are tritium emissions associated with PIE of the TPBARs at Hanford. About $1700 \mathrm{Ci}$ of tritium could be released in emissions from the 325 Building stack over the course of the planned PIE activities, and up to $6000 \mathrm{Ci}$ might be associated with the maximum Proposed Action (see Table 5.1). For comparison, 6.6 Ci of tritium were discharged from Hanford facilities during 1995 (Dirkes and Hanf 1996).

The dose to a maximally exposed member of the public from the potential tritium emissions could range from 0.095 to $3.3 \mathrm{mrem}\left(9.5 \times 10^{-7}\right.$ to $3.3 \times 10^{-5} \mathrm{~Sv}$, see Table 5.1), compared to the 1995 dose from air emissions $\left(0.0065 \mathrm{mrem}\right.$ [ $\left.\left.6.5 \times 10^{-8} \mathrm{~Sv}\right]\right)$ or the total dose $\left(0.023 \mathrm{mrem}\right.$ [ $\left.\left.2.3 \times 10^{-7} \mathrm{~Sv}\right]\right)$ from Hanford Site activities during 1995 (Dirkes and Hanf 1996). However, planned PIE activities would amount to less than $1 \%$ of the $10 \mathrm{mrem} / \mathrm{yr}\left(1 \times 10^{-4} \mathrm{~Sv} / \mathrm{yr}\right)$ standard for air emissions from DOE facilities, and the dose from the maximum potential emissions would represent less than $3.3 \%$ of the standard (Table 5.1). The Proposed Action would not likely all take place during a single year, thereby lowering the relative annual contribution. In addition, these activities would not continue over the long-term, and any cumulative impacts in conjunction with future research, waste management or remediation activities at the site would be temporary.

The collective dose from air emissions to the population within $50 \mathrm{mi}(80 \mathrm{~km})$ of the Hanford Site from planned PIE activities (0.41 person-rem) or maximum PIE (1.4 person-rem) is comparable in magnitude to the dose from Hanford operations in recent years (0.5 to 1 person-rem/yr, Dirkes and Hanf 1996). Therefore if the PIE activities were conducted within a period of 1 year, the collective dose to the population surrounding Hanford might increase by a factor of 2-3. However, the collective dose from Hanford Site activities is much lower in recent years than during the peak years of its defense mission, and the additional dose from PIE would be inconsequential compared with 100,000 person-rem from past site operations (TSP 1994). The collective dose from PIE would also be much lower than the dose from natural background radiation to the population surrounding the site, which amounts to 85,000 person-rem/yr.

Routine air emissions of radionuclides are not anticipated during other activities associated with the Proposed Action, nor would emissions of nonradiological air pollutants increase at any location where these activities take place. Therefore, there would be no potential for cumulative impacts associated with air emissions at locations other than the Hanford Site. 


\subsubsection{Cumulative Impacts on Water Quality}

The maximum estimated tritium emissions to surface water during irradiation of TPBAR-LTAs at WBN (less than $214 \mathrm{Ci} / \mathrm{yr}$ ) would increase the normal operating emissions of that radionuclide by less than $20 \%$, compared with the estimated $1300 \mathrm{Ci}$ annual emissions under typical operating conditions (see section 4.3 and NRC 1995). The estimated dose to a maximally exposed individual downstream from the TPBAR emissions would not measurably increase the $0.7 \mathrm{mrem} / \mathrm{yr}\left(7.0 \times 10^{-6} \mathrm{~Sv} / \mathrm{yr}\right)$ routine dose from the reactor's liquid effluents (see Section 5.2). Routine liquid effluents from other activities associated with the Proposed Action are not expected.

\subsubsection{Cumulative Impacts on Waste}

The maximum quantity of low-level radioactive waste that might be disposed of at Hanford as a result of the Proposed Action (approximately $220 \mathrm{~m}^{3}$ or $290 \mathrm{yd}^{3}$, including eventual disposal of contaminated equipment) is a very small fraction of the $89,000 \mathrm{~m}^{3}\left(120,000 \mathrm{yd}^{3}\right)$ of low-level waste currently awaiting disposition or that is expected to be generated over the next 20 years at the site (DOE 1997). No impacts on site waste disposal capabilities are expected. The quantities and persistence of radionuclides in the waste are such that no impact of waste disposal on groundwater or surface water is expected.

Quantities of mixed or hazardous waste are expected to be small compared with those of low-level radioactive waste and, likewise, would not affect overall site waste management capacity for those waste types. To minimize their future impact on the environment, all hazardous and radioactive wastes would be disposed of according to state and federal regulations.

The quantities of wastes generated at locations other than Hanford are much smaller than the volumes of waste typically handled at those facilities, and are not expected to impact waste management practices at those facilities.

\subsubsection{Cumulative Impacts on Transportation}

The radiological consequences of transportation to the transport crew and the public, 0.9 and 3.4 personrem ( 0.009 and 0.034 person-Sv), respectively, are very small compared with other ongoing or anticipated transportation activities such as those associated with activities regulated by the NRC ( 5600 person-rem/yr [ 56 person-Sv/yr] to workers and 4200 person-rem/yr [ 42 person-Sv/yr] to the public) or by DOE shipments to a geologic repository (up to 8600 person-rem [ 86 person-Sv] to workers and 48,000 personrem [ 480 person-Sv] to the public) (DOE 1995b). The risk of LCF from transportation accidents is much less than one over the course of the Proposed Action, which represents a negligible increase in the risk of such events over the routes that would be used.

Non-radiological transportation impacts resulting from vehicle emissions or transportation accidents are not anticipated to increase because of the Proposed Action.

\subsubsection{Cumulative Impacts on Health and Safety}

The risk of LCF from routine radiological exposures to both workers and the public is much less than one, and the small increase in risk would not be observable against the background of natural cancer cases, which averaged 173 per 100,000 nationwide in 1996 (ACS 1996). The risk to the public associated with routine activities is also generally lower than that from exposure to natural background radiation, which averages about $300 \mathrm{mrem} / \mathrm{yr}$ to an average individual (1 in 7000 risk of LCF).

The collective radiation dose to workers from routine activities, expected to be less than 3 person-rem (0.03 person-Sv), is much lower than the estimated annual collective dose to workers at WBN (190 person- 
rem/y [1.9 person-Sv/yr], NRC 1995) or the Hanford Site (290 person-rem [ 2.9 person-Sv] in 1995) and would not be expected to increase the risk to workers at those facilities.

\subsection{Impacts of Alternatives to the Proposed Action}

The consequences of alternatives to the Proposed Action are discussed in this section. Alternatives that were considered include: no action, use of alternate reactors to irradiate the TPBAR-LTAs, use of alternate DOE laboratories to perform the PIE, and use of non-government facilities for examination of the TPBARs. In general, the types of activities described for the Proposed Action would also be conducted under each of the alternatives, except that none of the activities would be conducted under the no-action alternative. The potential impacts associated with each alternative are discussed in the following sections.

\subsubsection{No-Action Alternative}

Under the no-action alternative by definition the Proposed Action would not take place. The major impacts of this alternative would be programmatic, in that information obtained by the irradiation and examination of the TPBARs would not be available. Lack of that data would impair DOE's ability to make decisions related to long-term options for tritium production as described in the programmatic EIS for tritium supply and recycling (DOE 1995a). As part of the Record of Decision for that EIS, DOE decided to pursue a dual track strategy for maintaining the supply of tritium for defense purposes and would evaluate tritium production using either an accelerator or a CLWR. The Proposed Action would aid in establishing whether the latter option might prove feasible as a long-term source of tritium.

Because the environmental impacts of the Proposed Action are minimal, the environmental risks would not change substantially if these activities were not performed. The operations and environmental impacts associated with each of the sites and facilities under consideration would remain as described in section 4 of this EA.

\subsubsection{Use of an Alternate Reactor for Irradiation of the TPBAR-LTAs, or Use of Alternate DOE Laboratories for Examination of the TPBARs}

A number of commercial reactors similar in design to WBN are currently operating in the United States, and could potentially be used for the proposed tests. However, these facilities would not provide the optimal schedule for conducting the tests, and the managing utilities may not be willing to participate in the project. Use of an alternate facility for the irradiation task could result in a delay in obtaining the information needed to make a timely decision regarding options for tritium production and would substantially increase costs. Restrictions by some commercial fuel vendors on use of their products for weapons-related research would also preclude use of reactors that obtain their fuel from those suppliers. The environmental impacts of the tests would be very similar at any facility of comparable design and would only differ to the extent that the size and location of the surrounding population may affect the consequences to a maximum individual or the collective population.

Examination of the TPBARs at an alternate DOE facility would necessitate transferring technology that is currently in use at the proposed facilities and could therefore result in delays and additional costs in performing the tests. As with an alternate reactor location, the types of activities to be performed at the alternate facilities would be the same as those proposed, and the environmental impacts would depend on their location relative to the surrounding residents. To the extent that relocating the PIE tasks might involve facility modifications or new construction, the environmental consequences would be greater than those associated with using the proposed existing facilities.

\subsubsection{Use of Non-DOE Facilities for Examination of the TPBARs}


The feasibility of using non-government facilities to examine the TPBARs is limited by the security needed to perform classified work for the DOE. Implementing appropriate procedures and obtaining security clearances would delay the conduct of the proposed tests, as would the need to transfer the technology and equipment required to perform them. Few facilities are equipped to handle the quantities of radioactive materials that would be generated during irradiation of the TPBARs, and relocation of the examination task would likely necessitate construction of new facilities or extensive modification of existing laboratories. 



\subsection{Permits and Regulatory Requirements}

It is the policy of DOE to carry out its operations in compliance with all applicable federal, state, and local laws and regulations, Presidential Executive Orders, and DOE Orders. The Proposed Action would follow pollution prevention requirements under Executive Order 12856: Federal Compliance with Right-To-Know Laws and Pollution Prevention Requirements.

Environmental regulatory authority over the Hanford Site is vested in federal and Washington State agencies. The Proposed Action would comply with applicable regulations and requirements. Prior to receipt of the TPBAR-LTAs, a Notice of Construction may need to be submitted to the State of Washington Department of Health for modification to the air permit that the 325 Building is operating under. Additional information on laws and regulations applicable to DOE actions at Hanford is detailed in Neitzel (1996).

Placement of the TPBAR-LTAs in WBN will require that the TVA submit a license amendment request to the NRC. The purpose of the license amendment is to obtain NRC review and approval of the use of TPBARs in WBN prior to the actual placement of the TPBARs in the reactor. The process used by the $\mathrm{NRC}$ to grant this approval is through an amendment to the facility operating license (through the plant Technical Specifications, which are incorporated in the license). 



\subsection{Agencies Consulted}

This environmental assessment was sent to the following for a 15-day review period:

- Nez Perce Tribe

- the Confederated Tribes of the Umatilla Indian Reservation

- the Wanapum

- the Yakama Indian Nation

- State of Idaho

- State of Tennessee

- State of Washington

- City of Richland, Washington

- Benton County, Washington

- U.S. Fish and Wildlife Service

- U.S. Nuclear Regulatory Commission

- Other Interested Parties

The TVA was cooperating agency with DOE in preparation of this EA in anticipation of its application to NRC for amendment of the WBN operating license, as discussed in Section 6.0.

During preparation of the draft EA, a comment letter prepared by the Yakama Indian Nation was received. The letter requested that an environmental impact statement (EIS) be prepared. This comment and any comments received during the review period of this document were considered by DOE in making a determination to proceed with an EIS or in making a finding of no significant impact (FONSI).

A comment letter from the State of Washington, Department of Ecology, was received during the 15 day comment period. The comment letter requested that the proposed activities be conducted in a manner that supports the work and schedules identified in the Hanford Federal Facility Agreement and Consent Order. The activities proposed will be conducted in accordance with the agreement and Consent Order.

A comment letter was also received from the State of Tennessee. The comment letter asked for clarification on the specific performance of the TPBARs. Much of the information requested is contained in the Erickson, et al 1997 reference cited in the document and was provided to the State of Tennessee in a response letter. 



\subsection{References}

10 CFR 1021.1996, "National Environmental Policy Act; Implementing Procedures and Guidelines," Code of Federal Regulations, as amended.

60 FR 63877-63891. December 12, 1995. U.S. Department of Energy. "Record of Decision: Selection of Tritium Supply Technology and Siting of Tritium Supply and Recycling Facilities." Federal Register.

Executive Order 12856. Federal Compliance with Right-to-Know Laws and Pollution Prevention Requirements.

American Cancer Society (ACS). 1996. "Cancer Facts and Figures 1996." American Cancer Society, Atlanta, Georgia.

Atomic Energy Act of 1954, 42 USC 2011 et seq.

Bergsman, K.E, T.B Bergman, D.W. Bergmann, G.E. Costley, M.T. Jansky, M. Kummerer, R.L. McCormack, M.J. Monthey, A.N. Praga, I.K. Ullah, W.L. Willis, and A.G. Hosler. 1995. K Basin Environmental Impact Statement Technical Input. WHC-SD-SNF-TI-013, Rev. 0. Westinghouse Hanford Company, Richland, Washington.

Brown, R. M., G. L. Ogram, and F.S. Spencer. 1990. "Oxidation and Dispersion of HT in the Environment: The August 1986 Field Experiment at Chalk River," Health Phys. 58(2):171-181.

Dirkes, R.L. and R.W. Hanf (eds). 1996. Hanford Site Environmental Report for Calendar Year 1995. PNNL-1 1139. Pacific Northwest National Laboratory, Richland, Washington.

Endangered Species Act of 1973, 16 USC 1531 et seq.

Erickson, LW, A. Lopez, E.F. Love, B.E. Schmitt, E.R. Gilbert, R.L. Van Witbeck, 1997. Report on the Evaluation of the Tritium Producing Burnable Absorber Rod Lead Test Assembly. PNNL-11419, Rev. 1. Pacific Northwest National Laboratory, Richland, Washington.

International Commission on Radiological Protection (ICRP). 1991. 1990 Recommendations of the International Commission on Radiological Protection. ICRP Publication 60, Annals of the ICRP Vol 21 (1-3), Pergamon Press, Oxford.

Johnson, P.E., D.S. Joy, D.B. Clarke, and J.M. Jacobi. 1993. HIGHWAY 3.3, An Enhanced Highway Routing Model: Program Description, Methodology, and Revised User's Manual. ORNL/TM-12124. Oak Ridge National Laboratory, Oak Ridge, Tennessee.

Napier, B.A., R.A. Peloquin, J.V. Ramsdell, and D.L. Strenge. 1988. GENII - The Hanford Environmental Radiation Dosimetry Software System. PNL-6584, Vol. 1-3, Pacific Northwest Laboratory, Richland, Washington.

Neitzel, D.A. (ed.). 1996. Hanford Site National Environmental Policy Act (NEPA) Characterization. PNL-6415, Rev. 8. Pacific Northwest National Laboratory, Richland, Washington.

National Environmental Policy Act of 1969, 42 U.S.C. 4321 et seq. 
Neuhauser, K. S., and F. L. Kanipe. 1992. RADTRAN 4: Volume 3 -- User Guide. SAND89-2370, Sandia National Laboratories, Albuquerque, New Mexico.

Rao, R. K., E. L. Wilmot, and R. E. Luna. 1982. Non-Radiological Impacts of Transporting Radioactive Material, SAND81-1703, Sandia National Laboratories, Albuquerque, New Mexico.

Saricks, C., and T. Kvitek. 1994. Longitudinal Review of State-Level Accident Statistics for Carriers of Interstate Freight. ANL/ESD/TM-68, Argonne National Laboratory, Argonne, Illinois.

Tennessee Valley Authority (TVA). 1991. Watts Bar Nuclear Plant. Final Safety Analysis Report. Tennessee Valley Authority, Chattanooga, TN.

Tichler, J., K. Doty, and K. Lucadamo. 1995. Radioactive Materials Released from Nuclear Power Plants. Annual Report 1993. NUREG/CR-2907, BNL-NUREG-51581, Vol. 14. U.S. Nuclear Regulatory Commission, Washington, D.C.

TSP (Technical Steering Panel of the Hanford Dose Reconstruction Project). 1994. Summary: Radiation Dose Estimates from Hanford Radioactive Material Releases to the Air and to the Columbia River. Centers for Disease Control and Prevention, Atlanta, Georgia.

U.S. Department of Energy (DOE). 1995a. Final Programmatic Environmental Impact Statement for Tritium Supply and Recycling. DOE/EIS-0161. U.S. Department of Energy, Washington, D.C.

U.S. Department of Energy (DOE). 1995b. Department of Energy Programmatic Spent Nuclear Fuel Management and Idaho National Engineering Laboratory Environmental Restoration and Waste Management Programs Final Environmental Impact Statement. DOE/EIS-0203-F, Volume 2, Part A. Office of Environmental Management, Idaho Operations Office, U.S. Department of Energy, Idaho Falls, Idaho.

U.S. Department of Energy (DOE). 1996. DOE Performance Indicators for Environment, Safety and Health. Report Period Ending March 1996. Office of Environment, Safety and Health U.S. Department of Energy, Washington, D.C. (Available on the World Wide Web at: http://www.eh.doe.gov/pi)

U.S. Department of Energy (DOE). 1997. Final Waste Management Programmatic Environmental Impact Statement for Managing Treatment, Storage, and Disposal of Radioactive and Hazardous Waste. DOE/EIS-0200-F. Office of Environmental Management, U.S. Department of Energy, Washington, D.C.

U.S. Nuclear Regulatory Commission (NRC). 1995. Final Environmental Statement Related to the Operation of Watts Bar Nuclear Plant, Units I and 2. NUREG-0498, Office of Nuclear Reactor Regulation, U.S. Nuclear Regulatory Commission, Washington, D.C.

U.S. Nuclear Regulatory Commission (NRC). 1997. Safety Evaluation Report Related to the Department of Energy's Proposal for the Irradiation of Lead Test Assemblies Containing Tritium-Producing Burnable Absorber Rods in Commercial Light-Water Reactors. NUREG-1607, U.S. NRC, Washington, D.C. 


\section{Appendix A}

Description of the Tritium-Producing Burnable Absorber Rod for The CLWR Lead Test Assembly 

DESCRIPTION OF THE TRITIUM-PRODUCING BURNABLE ABSORBER ROD FOR THE CLWR LEAD TEST ASSEMBLY

TRITIUM TARGET QUALIFICATION PROJECT

\author{
TTQP-1-015 \\ REVISIONO
}

September 1996

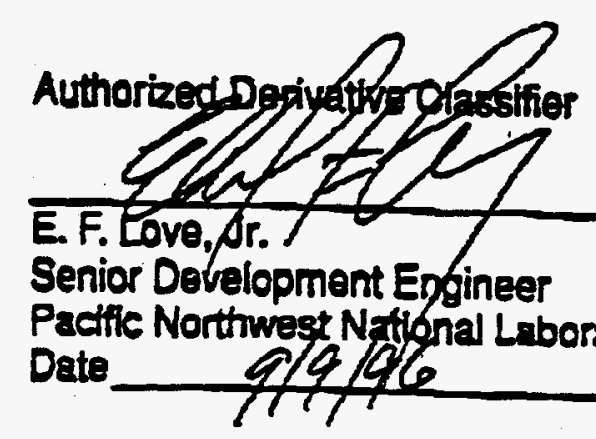




\section{DESCRIPTION OF THE TRITIUM-PRODUCING BURNABLE ABSORBER ROD FOR THE CLWR \\ LEAD TEST ASSEMBLY}

TRITIUM TARGET QUALIFICATION PROJECT

SEPTEMBER 1996

TTQP-1-015

Revision 0

Prepared by: $\quad$ E.R. Gilbert. Contractor. Mohr and Associates. Richland. Washington

Concurrence:
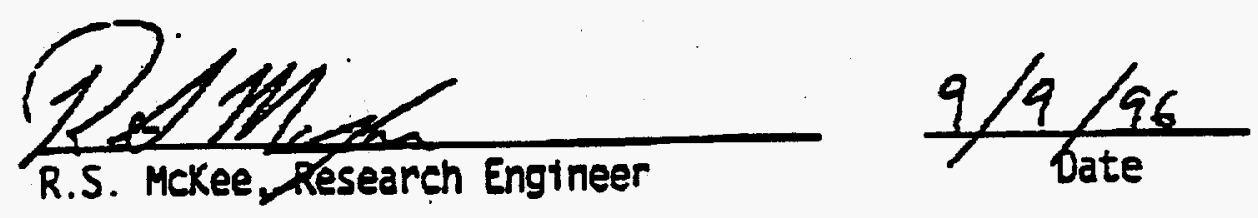

Approved:

$$
\text { Ini denet }
$$

B.M. Durst. Task Manager

Design and Systems Engineering

Approved:

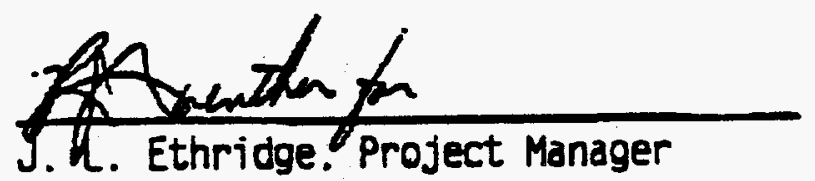

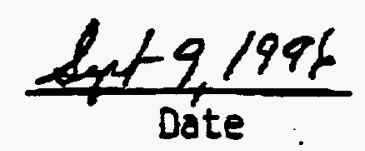


TTOP-1-015

Septenber 1996

\title{
DESCRIPTION OF THE TRITIUM-PRODUCING BURNABLE ABSORBER ROD FOR THE CLWR LEAD TEST ASSEMBLY
}

\begin{abstract}
This document provides an unclassifled description of the Commercial Light Water Reactor (CLWR) tritium-producing burnable absorber rod (TBAR) to be irradiated in the Lead Test Assembly (LTA) for the Tritium Target Qualification Project (TTQP). Th1s description provides information for coordination with contractors assoclated with the TOP.
\end{abstract}

\subsection{INTRODUCTION}

The purpose of this dociment is to provide an unclassifted description of the TBAR design for the LTA to be irradiated in a CLWR. This design is derived from the New Production Light Water Reactor (NP LWR) Target Rod (2) and has been estabilshed as the reference CLWR TBAR design for the LTA. The TBAR is intended to be similar in form and nuclear characteristics to a PWR burnable absorber rod. Materials. component specifications. performance features. and functional requirements are described in the Phase 1 Design. Review Documents ${ }^{(2.3)}$.

\subsection{DESCRIPTION OF THE TBAR FOR THE LTA}

The TBAR LTA is constructed of materials that have been chosen for their ability to perform successfully in in-reactor and ex-reactor test programs and for their compatibility with the other reactor internals. fuel assemblies. and the reactor coolant system. The TBAR LTA upper structure assembly is shown in Appendix 1 for a typical Babcock \& Wllcox design used in a Westinghouse $17 \times 17$ 
fuel assembly. The actual LTA will utilize a standard Westinghouse design holding 32 TBAR's. The material within the absorber rods have been selected to reflect design characteristics suitable for the production of tritium. Quality standards for material selection. fabrication. and inspection will be specified to ensure that important functions are maintained.

Basically, the TBAR is of the getter-barrier type. similar in form and nuclear characteristics to a pressurized water reactor (PWR) burnable absorber rod. Lithium aiuminate pellets are enriched with an appropriate density and composition of $\mathrm{Li}$ atoms to produce tritium and to simulate the nuclear characteristics of a burnable absorber rod. The target rod for the CLWR production core will be designed to provide the capability for a full core production rate of tritium in a PWR type environment of at least $2 \mathrm{~kg} / \mathrm{y}$ (unclassified goal) while releasing less than $20.000 \mathrm{Cl} / \mathrm{y}$ tritium to the reactor coolant. However. the primary goal of the LTA is to address institutional issues and the tritium production will be limited to 0.5 to 0.75 $g$ of tritiun per TBAR. The LTA is composed of 32 TBARs in burnable absorber rod locations. The LTA will be loaded with TBARs only and will not include other absorber rods. The design life of the TBAR is 550 equivalent full-power days (EFPD) of in-reactor operation.

An isometric section of a getter-barrier TBAR is shown in Figure 1 to illustrate the arrangement of the components. The TBAR design consists of concentric cylindrical subcomponents clad with Type 316 stainless steel (3165S). The 31655 cladding provides structural strength to the TBAR. To prevent tritium from diffusing into the reactor coolant from the TBARs and hydrogen in the coolant from diffusing inward. the inner surface of the 31655 cladding is pack aluminized to depth of several mils. The barrier coating must have sufficient adhesion and toughness. so as not to peel or blister during fabrication. handling. and in-reactor operations. Without this permeation-resistant barrier. hydrogen could saturate the NPZ getters. rendering them ineffective for capturing tritium. 
To maintain a low partial pressure of tritium within the target rods. a getter tube composed of nickel-plated Zircaloy-4 (NPZ) surrounds the $\mathrm{LiAlO}_{2}$. The getter is enclosed within the cladding. The nickel coating on the NPZ getter maintains the effectiveness for tritium absorption by preventing the formation of $\mathrm{ZrO}_{2}$ on the surface. Tritium.produced in the $\mathrm{LAAlO}_{2}$ pellets is released and reacts with the NPZ getter to form solid zirconium tritide within the getter. The pressure of tritium in equilibrium with the NPZ getters at operating terperatures is low; thus, the driving force for tritium permeation through the cladding is also low. As indicated in Figure 2. an NPZ getter disk is located at the botton of the TBAR and another in the plevium at the bottom of the compression spring located at the top of the TBAR. These lwe getter disks limit tritium leakage through the uncoated welds and through the top and bottan end plugs.

Because some tritium is released from the $\mathrm{LIAlO}_{2}$ in the form of $\mathrm{T}_{2} \mathrm{O}$. a Zircaloy-4 liner is placed inside the annular $L_{i A l O}$ pellets to reduce $T_{2} O$ by forming an oxide on the surface of the Zircaloy-4 liner and by releasing tritium so that it can be absorbed by NPZ getter or the liner. The 1iner also provides mechanical support to prevent axial relocation of the $\mathrm{LiAlO}_{2}$ pellet material in the event any becomes fragmented.

The tritium is produced in a stack of NPZ getter subassembiles (penci1s) containing the $\mathrm{LiAlO}_{2}$ pellets. The getter subassemblies permit free exchange of gas within the target rod. but limit the axial movement of $\mathrm{LiAlO}_{2}$ pellet material in the event any becomes fragmented. The TBAR is designed to use the same end plugs and to be the same length and diameter of the PWR burnable absorber rods they replace.

An NPZ getter tube surrounds the compression spring at the top of the pellet column to provide additional gettering material and surface area. thus reducing the partial pressure of tritium at the top of the target rod. The compression spring is fabricated from stainless steel and is similar to 
springs used for PWR fuel and burnable absorber rods. The primary function of the plenum spring is to provide an axial force to restrain the stack of getter subassemblies during handling and shipping operations. while allowing for thermal axtal growth of the getter subassenblies in the reactor. For closure of the target rods. end fittings (similar to those used in burnable absorber rods) are welded to each end of the cladding tube.

\subsection{REFERENCES}

1. Weber. J.W. 1991. NP IWR Target Rod Desian Description. WHC-SC-WNPDB-002. Rev. 1. Kestinghouse Hanford Company, Richland, Washington.

2. Durst. B.M. December 1995. Iritium Iarget Oualification Proaram Phase L Desian Review Plan. PNNL-TTOP-001 (CRD). Tritium Target Qualification Project. Pacific Northwest National Laboratory, Richland. Washington.

3. Durst. B.M and E.R. Gilbert. January 1996. Supplementary Information Phase 1 Desian Review Plan. PNNL-TTOP-002 (CRD). Tritium Target Qualification Project. Pacific Northwest National Laboratory, Richland. Washington. 
TTOP-1-015

September 1996

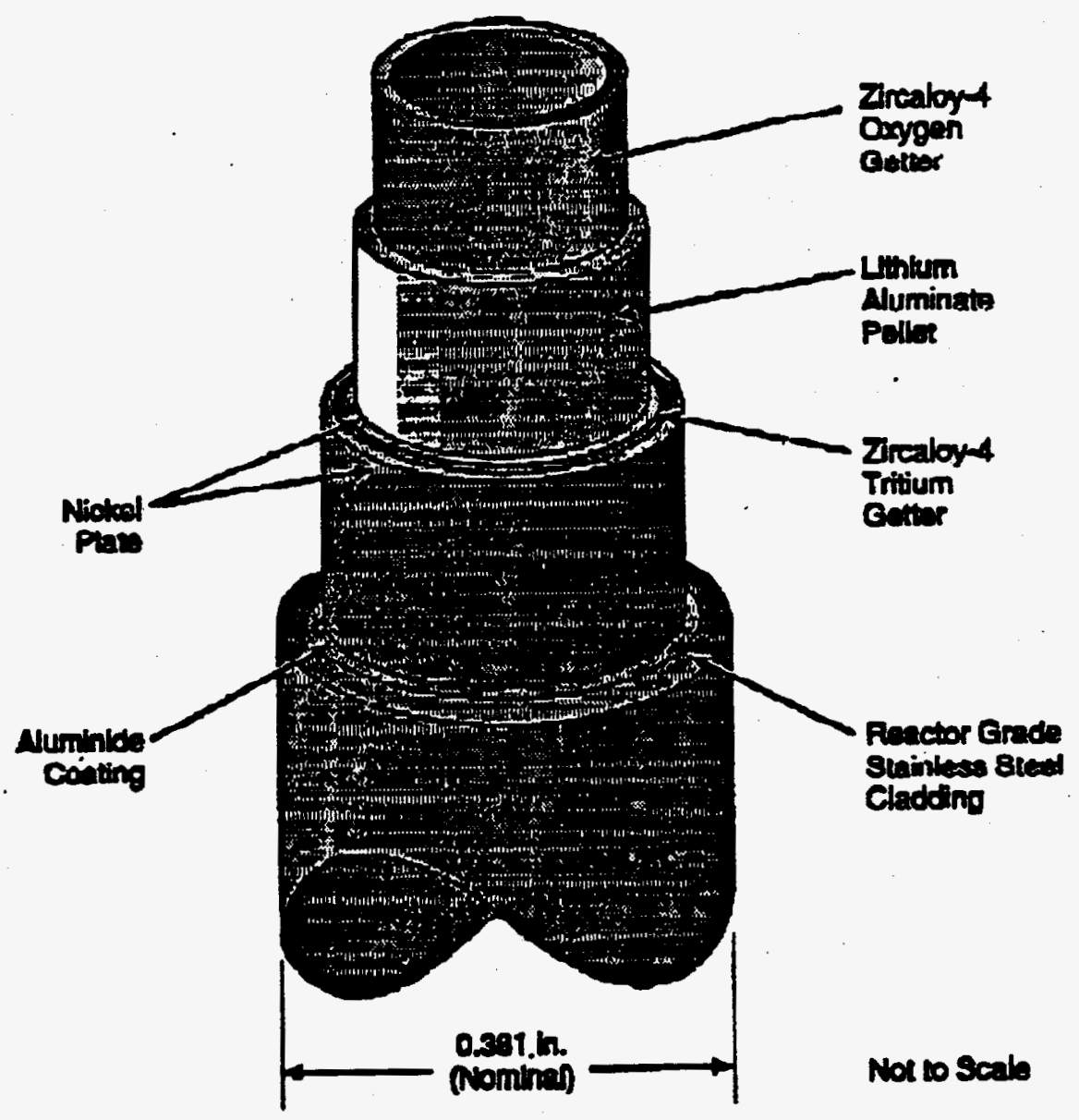

Figure 1. Isometric SAction of a Trityum Producing Burnabie Absorber Rod 


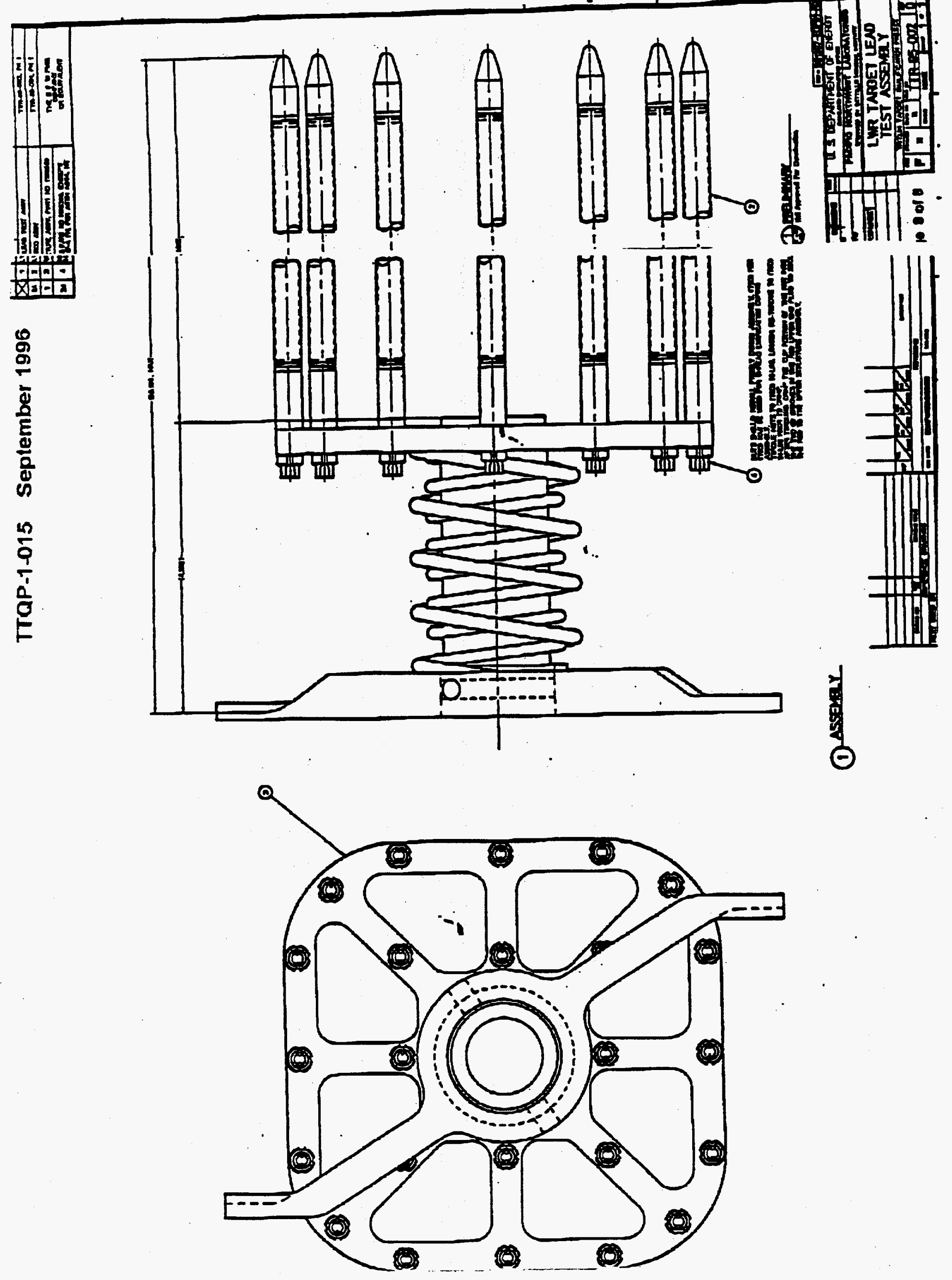


Appendix B

Biological Review of the

Tritium Target Lead Test Assembly, 300 Area 

January 20, 1997

C. A. Brandt

K6.84

$376-5345$

Ms. Julie K. Turner

U.S. Departmert of Energy

Richlend Operations Office

P. O. Box 550. l:ISIN K8-50

Richland, WA $§ § 352$

Jear Ms. Turner:

BIOLOGICAL REVIEW OF TRITIUM TARGET/LEAD TEST ASSE::BLY, $32 \equiv \equiv$ LDG., 300 AREA. $\$ 07-300-010$

Project Description:

- This biological review applies to that portion of the subjezt zroject that ir:cludes modifications to the 325 Building.

\section{Survey Objectives:}

- To determine the occurrence in the project area of plant and animal species protected under the Endangered Species Act (ESA), candidates for such protection, and species listed as threatened, endang=red. candidate, sensitive. or monitor by the state of Washin z:on. and species protected under the Migratory Bird Treaty Act.

- To eveliate the potential impacts of disturbance on pricr.: habitats :- $=$ protected plant and animal species identified in the survey.

\section{Survey Methods:}

- A field survey of the project area was conducted by T. t.:- jrahan an. R. Burrows on May 21, 1996. The Braun-Blanquet cover-abundance scale (Bonham $i \leqslant 59$ ) was $u \leq: j$ to determine percent cover of dominant vegetation.

- Priority habitats and species of concern are documented $\equiv s$ such in :" $=$ following: Washington Depariment of Fish and Wildlife $(1994,1995)$, U. S. Fist: - .J Wildife sarvice $(1985,1992,1994)$ and Washington State Department of Natural Resources (15: ' $?$.

Survey Results:

- The vicinity of the project area has been previously distui: 3 . Vege ". in is characteristic of disturbe $d$ areas, consisting primarily of packed gravel an. : قvemer: cheatgrass (Bromus tectorum) and Russian thistle (Sals ; ; kalt).

- No migratory birds were observed hesting in the vicinity $c^{\circ}$ the $\mathrm{fr}: \quad$ : $:$ a. 


\section{Conclusions:}

- This biological survey is effective until April 15, 1997. Should the project described above commence after this date, a new ecological review will be required.

- No plant or animal species protected under the ESA, candidates for such protection, or species listed by the Washington state government were observed in the vicinity of the project location.

- No adverse impacts to species or habitats of concern are expected to occur from the proposed action.

Sincerely,

CA Brandt, Ph.D

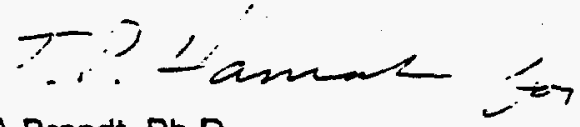

Project Manager

Ecological Compliance Assessment

CAB:tph

\section{REFERENCES}

Bonham, Charles D. 1989. Measurements for Terrestrial Vegetation, published by John Wiley \& Sons, Inc. pp. 127-128.

U. S. Fish and Wildife Service. 1985. Revised List of Migratory Birds; Final Rule. 50 FR 13708 (April 5, 1985).

U. S. Department of Interior, U. S. Fish and Wildlife Service. 1992. Endangered and Threatened Wildife and Plants. 50 CFR 17.11 and 17.12. (August 29, 1992).

U. S. Fish and Wildife Service. 1994. Endangered and Threatened Wildife and Plants, Animal Candidate Review for Listing as Endangered or Threatened Species, Proposed Rule, 50 CFR 17. (November 15, 1994).

Washington Department of Fish and Wildlife. 1994. Species of Special Concern in Washington. (April 1994).

Washington Department of Fish and Wildlife. 1995. Priority Habitats and Species. 24 pp.

Washington Department of Natural Resources. 1994. Endangered, Threatened \& Sensitive Vascular Plants of Washington. (January 1994). 


\section{Appendix C \\ Consequences of Tritium Releases During Post-Irradiation Examination of Tritium-Producing Burnable Absorber Rods (TPBARs)}

Post Irradiation Examination (PIE) of the TPBARS would take place at Hanford, and neutron radiography would be conducted at a facility to be determined. For the purposes of this analysis, neutron radiography is assumed to occur at the ANL-W facility, near Idaho Falls, Idaho.

PIE of the TPBARs would take place at the PNNL Applied Chemistry Laboratory, designated the 325 building, which is located in the Hanford Site 300 Area. These activities may result in releases of tritium, as well as very small quantities of particulate activation products, to the environment. Routine releases could result from destructive examination of the TPBARs, extraction of tritium to determine production levels and retention efficiency, and permeability tests of the TPBAR cladding material. Accidental releases might result from damage to a TPBAR during handling, malfunctions of facility emission control equipment during PIE activities, or external events such as a fire or earthquake. The consequences of both routine emissions and potential accident scenarios have been evaluated for PIE activities, as described in the following sections.

\section{C.1 Methods for Evaluation of Potential Consequences of PIE Activities}

Radiation dose estimates were calculated using the CAP88-PC software package (Parks 1992) for routine emissions, and the GENII software system (Napier et al 1988) for acute (short-term) releases. Both codes implement a straight-line Gaussian plume model for atmospheric dispersion, and the food chain models are similar to those of NRC (1977) for ingestion dose estimates. The GENII software incorporates a seasonal model for ingestion calculations following an acute release that accounts for the types and quantities of food products growing during each season, as well as the delay time between radionuclide deposition and harvest. The atmospheric dispersion and air concentrations for chronic releases are based on annual average atmospheric conditions, and acute releases assume conditions that would not be exceeded more than $5 \%$ of the time. The dosimetry models in both codes are consistent with recommendations of the International Commission on Radiological Protection (ICRP) in its publications 26 (ICRP 1979) and 30 (ICRP 1979-1988). Other assumptions are based on recommended parameters for the Hanford Site in Schreckhise et al (1993).

The dose resulting from release of tritium to the environment would depend on its chemical form. The inhalation dose from oxidized tritium (as HTO or $\mathrm{T}_{2} \mathrm{O}$ ) is about 14,000 times higher than for tritium in elemental form (as $\mathrm{HT}$ or $\mathrm{T}_{2}$ ). Elemental tritium is also assumed to make no contribution to doses received via the food chain (ingestion) pathways (DOE 1988). The dosimetry models in both the CAP88-PC and GENII codes assume that tritium is released to the environment in the oxidized form, and therefore are conservative for releases that involve elemental tritium. For this analysis, tritium released in elemental form is assumed to oxidize slowly in the environment. Based on experimental results, Brown et al. (1990) estimate the long- 
term dose from elemental tritium releases to be about $1 \%$ of that for the oxidized form. Therefore, releases that occur as elemental tritium are multiplied by a factor of 0.01 to convert them to an equivalent release of tritium oxide for use with the environmental dosimetry software.

Health effects estimates are based on recommendations of the ICRP (1991) in its publication 60 . The consequences in terms of latent cancer fatalities are estimated to be $4 \times 10^{-4}$ per person-rem ( $4 \times 10^{-2}$ per person-Sv) for adult workers and $5 \times 10^{-4}$ per person-rem $\left(5 \times 10^{-2}\right.$ per person-Sv) for the general population. The corresponding total incidence of detrimental health effects, including both fatal and nonfatal cancers and severe hereditary effects, is estimated to be $5.6 \mathrm{x}$ $10^{-4}$ per person-rem $\left(5.6 \times 10^{-2}\right.$ per person-Sv) for workers and $7.3 \times 10^{-4}$ per person-rem $(7.3 \times$ $10^{-2}$ per person-Sv) for the general population. The higher rates for the general population account for the presence of more sensitive individuals, such as children, compared with the relatively homogeneous population of healthy adults in the work force. These estimates apply to radiation exposures at relatively low doses and dose rates (see ICRP 1991).

The ICRP estimates are based on radiation exposures to populations at higher doses and dose rates, and by different pathways, than those normally encountered in the environment. As a result, the health effects coefficients are presented in terms of collective dose to a relatively large population. Collective dose is defined as the sum of doses to all individuals in the population, who may exhibit a wide range of susceptibility to radiation-induced health effects. The health effects coefficients are therefore associated with substantial uncertainty when applied to dose estimates for individuals whose sensitivity may differ from the population average. However, the assumptions used to develop the health effects coefficients are sufficiently conservative that they would be "unlikely to underestimate the risks" (ICRP 1991).

\section{C.2 Consequences of Routine PIE Activities}

Non-destructive evaluation (NDE) of the TPBARs and neutron radiography would not involve breaching the cladding under normal conditions. Therefore, the NDE would not be expected to result in air emissions other than those typically associated with operation of the facility.

The remaining PIE of the irradiated TPBARs and associated tests would consist of 3 major activities: 1) sectioning the rods to evaluate changes to their internal structure, 2) extraction of tritium from the rods to determine production rates and retention characteristics, and 3) permeability testing of the TPBAR cladding material using tritium obtained from a commercial source. The radionuclide releases from each of these activities are estimated as follows:

1) Sectioning of TPBARs - Each TPBAR has an active target length of approximately 142 " and a bounding tritium inventory of $12,000 \mathrm{Ci}$. All tritium in the cut cross-section is presumed to be volatilized during the sectioning procedure. Assuming that the average distance between cuts is about 3.75", and the width of each cut is $0.015^{\prime \prime}$, the estimated tritium release from sectioning each TPBAR is calculated as follows:

H-3 Release = (total length of TPBAR $\div$ distance between cuts) $\mathrm{x}$ (cut width) $\mathrm{x}$ 


$$
\begin{aligned}
& \text { (TPBAR H-3 inventory per unit length) } \\
& =\left(142^{\prime \prime} \div 3.75 "\right) \times\left(0.015^{\prime \prime}\right) \times\left(12,000 \mathrm{Ci} / 142^{\prime \prime}\right) \\
& =48 \mathrm{Ci} / \mathrm{TPBAR} .
\end{aligned}
$$

All of the tritium that would be volatilized during sectioning is assumed to be released via the building's heating, ventilation and air conditioning (HVAC) system. Small quantities of neutron activation products in the TPBAR cladding would also be converted to particulate form during this operation, but the facility emission controls would limit their releases to such small quantities that they would have no consequence when compared with the tritium releases.

2) Tritium Extraction and Analysis - An estimated upper bound for emissions from the tritium extraction and analysis process were approximately $0.1 \%$ of the total inventory via the mass spectrometer and $1 \%$ via the emission control system (either a bubbler or molecular sieve trap). The potential emissions from extracting tritium from one TPBAR are as estimated follows:

$$
\begin{aligned}
\text { H-3 Release } & =(\text { TPBAR tritium inventory }) \times \text { (release fraction }) \\
& =(12,000 \mathrm{Ci}) \times(0.01+0.001) \\
& =130 \mathrm{Ci} / \mathrm{TPBAR} .
\end{aligned}
$$

3) Cladding Permeability Tests - An upper bound estimate for tritium emissions from the cladding permeability tests is $10 \%$ of the total inventory volatilized from the commercial tritium source, which contains approximately $2000 \mathrm{Ci}$. The remaining tritium was assumed to be recovered and contained within the source following the test. The tritium emissions from this activity were therefore estimated as:

$$
\begin{aligned}
\text { H-3 Release } & =(\text { Source tritium inventory }) \times(\text { release fraction }) \\
& =(2000 \mathrm{Ci}) \times(0.10) \\
& =200 \mathrm{Ci} .
\end{aligned}
$$

The consequences of routine tritium emissions were calculated using the CAP88-PC computer software and site-specific wind data from the Hanford Site 300 Area (Schreckhise et al 1993). The meteorological database represents the average of hourly data collected over the 9-year period from 1983 through 1991 at the 300 Area meteorological tower. Calculations were performed for a unit (1-Ci) release of tritium from the 325 building stack using normal ventilation parameters for stack EP-325-01-S. The effective stack height was set at $35 \mathrm{~m}$, the exit velocity at $13 \mathrm{~m} / \mathrm{s}$, and the diameter at $2.44 \mathrm{~m}$. Dose estimates are presented in Table C.1 for releases from all routine PIE activities. These results assume tritium is released in oxidized form, which provides a bounding estimate of the consequences. However, the tritium extraction process includes an oxidation step prior to trapping the gases in a bubbler or molecular sieve, so this assumption is not overly conservative for the specific processes considered in this assessment. 
Table C.1 Consequences of Routine Tritium Emissions from Post-Irradiation Examination of TPBARs at the Hanford Site 325 Building

\begin{tabular}{|l|l|l|}
\hline \multicolumn{1}{|l|}{ Consequences of Tritium Emissions from PIE Activities } \\
\hline & $\begin{array}{l}\text { Dose (mrem) to } \\
\text { the Maximally } \\
\text { Exposed Offsite } \\
\text { Resident }(2 \mathrm{~km} \mathrm{E})\end{array}$ & $\begin{array}{l}\text { Dose (person-rem) to } \\
\text { the population within } \\
50 \mathrm{mi}(80 \mathrm{~km})\end{array}$ \\
\hline PIE Activity and Estimated Tritium Release & $5.53 \times 10^{-5}$ & $2.4 \times 10^{-4}$ \\
\hline 1-Ci tritium release & & \\
\hline PIE Activities & $2.6 \times 10^{-3}$ & $1.2 \times 10^{-2}$ \\
Sectioning of 1 TPBAR (48 Ci) & $7.3 \times 10^{-3}$ & $3.1 \times 10^{-2}$ \\
Tritium Extraction from 1 TPBAR (130 Ci) & $1.1 \times 10^{-2}$ & $4.8 \times 10^{-2}$ \\
Cladding Permeability Tests (200 Ci) &
\end{tabular}

\section{C.3 Consequences of Accidents During PIE Activities}

The consequences of potential accidents during PIE of the TPBARs were evaluated for a spectrum of events having different severities and expected frequencies. A detailed safety analysis of the PIE activities would be performed before work commences; however, the scenarios evaluated for this assessment are representative of the types of events that are typically considered in safety assessments. Three accidents were evaluated for PIE activities, including: 1) breach of a single TPBAR during handling, 2) a localized fire involving the maximum quantity of tritium "at risk" during PIE, and 3) a seismic event and fire, which could involve all 32 TPBARs. A bounding accident during transport of the TPBARs between facilities was also evaluated. Accidents during PIE at Hanford are expected to bound those for similar types of events during neutron radiography because the facilities at ANL-W are farther from the nearest offsite receptors than those at Hanford (greater than $8 \mathrm{~km}$ vs $0.58 \mathrm{~km}$ ). In addition, the localized fire scenario would not apply to NDE activities because the TPBARs would remain intact and would therefore not be considered at risk for this type of accident.

\section{C.3.1 Rod Breach Scenario.}

The rod breach or similar scenario could release the gaseous (i.e., unbound) tritium content of a single TPBAR. This event is expected to occur with a frequency between $1 \times 10^{-2}$ and 1.0 per year (or one event in 1 to 100 years). Following irradiation, most of the tritium in the TPBARs is expected to be bound to the getter and other internal components. Based on experimental results of Johnson et al (1976), less than $30 \%$ of the TPBAR tritium inventory was assumed to be in a gaseous state, which would consist almost entirely of elemental tritium. Less than $0.5 \%$ of the total TPBAR tritium inventory would be expected to exist as gaseous tritium oxide. (Johnson et al 1976) If $1 \%$ of the free elemental tritium is assumed to oxidize in the environment following release (see section C.1), the total equivalent release as tritium oxide from a damaged TPBAR is calculated to be:

H-3 Release $=($ TPBAR inventory $) \times[($ free oxide fraction $)+($ free elemental fraction $) \mathbf{x}$ 
(fraction oxidized in environment)]

$=(12,000 \mathrm{Ci}) \times[0.005+(0.3 \times 0.01)]$

$=96 \mathrm{Ci}$.

The scenario for this event assumes that the tritium release is not mitigated by emission control devices.

\section{C.3.2 Localized Fire.}

A localized fire during PIE is assumed to involve release of all tritium considered to be at risk at any time in the 325 Building laboratories. The quantity at risk is assumed to be the total inventory of TPBARs that are undergoing tests at any given time. TPBARs that are intact and remain in their sealed storage containers within the hot cells are not considered to be at risk for this event. The quantity of tritium assumed to be at risk for this event is $70,000 \mathrm{Ci}$, which represents the content of 6-8 TPBARs. Because the event includes an external mechanism for releasing tritium bound in the TPBAR components and oxidizing it, the entire at-risk inventory is assumed to be released as tritium oxide. The estimated frequency of a localized fire is less than 0.10 , or 1 in 10 years, and the time required to complete the activity is less than 6 months.

\section{C.3.3 Seismic Event with Fire.}

The bounding accident for PIE involves an external event such as a severe earthquake and fire that could damage all 32 of the TPBARs simultaneously. The anticipated frequency of accidents in this category is between $1 \times 10^{-6}$ and $1 \times 10^{-4}$ per year (or one event in 10,000 to 1 million years). The release scenario for this accident assumes that the building is breached, allowing the entire tritium inventory of all 32 TPBARs $(385,000 \mathrm{Ci})$ to exit through an opening below the roof level with the HVAC system out of operation. Because this event includes a fire, the tritium was assumed to be oxidized prior to release from the building.

\section{C.3.4 Consequences of a Bounding Accident During Transportation}

The consequences of a bounding accident during transport of the TPBARs between Hanford and ANL-W were also evaluated. A maximum credible accident during transportation is assumed to breach the shipping container and damage all 32 TPBARs, releasing the free tritium inventory. The quantity of tritium oxide released is therefore equivalent to 32 times that estimated for the single rod breach in section C.3.1, or about $3100 \mathrm{Ci}$. The assumptions associated with this accident are discussed in detail in Appendix D, section D.4.2.

\section{C.4 Summary of Accident Consequences}

The dose to an individual located near the 325 Building was evaluated for each accident scenario described in Section C.3, and the results are presented in Table C.2. Atmospheric dispersion estimates and GENII results for a release of $1 \mathrm{Ci}$ of tritium from the 325 Building are included in Table C-2. The dose calculations for releases from the facility use atmospheric dispersion estimates ( $E / Q$ values) for a ground-level release including a building wake dispersion model. The dose per $\mathrm{Ci}$ tritium released in the bounding transportation accident was estimated from the corresponding value for facility accidents, adjusting for the higher air concentration at each 
receptor location following an open-area ground level release as follows:

Dose (mrem) per Ci Release $=\mathrm{mrem} / \mathrm{Ci}$ for facility accidents $\mathrm{x}(\mathrm{E} / \mathrm{Q}$ for open-area (Transportation accidents) ground level release $\div \mathrm{E} / \mathrm{Q}$ for release from facility)

$$
\begin{array}{ll}
\text { 100-m receptor: } & =3.6 \times 10^{-2} \times\left(3.4 \times 10^{-2} \div 1.2 \times 10^{-3}\right) \\
& =1.0 \times 10^{0} \\
580-\mathrm{m} \text { receptor: } & =4.2 \times 10^{-3} \times\left(1.7 \times 10^{-3} \div 1.4 \times 10^{-4}\right) \\
& =5.1 \times 10^{-2}
\end{array}
$$

\begin{tabular}{|c|c|c|c|}
\hline $\begin{array}{l}\text { Accident Releases - } 325 \text { Bldg. } \\
\text { H-3 Release (as tritium oxide) }\end{array}$ & $\begin{array}{l}\text { Onsite Dose, mrem } \\
100 \mathrm{~m} \text { ESE } \\
\mathrm{E} / \mathrm{Q}=1.2 \times 10^{-3} \\
\mathrm{~s} / \mathrm{m}^{3}\end{array}$ & $\begin{array}{l}\text { Offsite Dose, mrem } \\
580 \mathrm{~m} \text { ESE } \\
\mathrm{E} / \mathrm{Q}=1.4 \times 10^{-4} \\
\mathrm{~s} / \mathrm{m}^{3}\end{array}$ & $\begin{array}{l}\text { Collective Dose to Offsite } \\
\text { population, person-rem }\end{array}$ \\
\hline $1 \mathrm{Ci}$ & $3.6 \times 10^{-2}$ & $4.2 \times 10^{-3}$ & $1.5 \times 10^{-2}$ \\
\hline TPBAR Breach $(96 \mathrm{Ci})$ & $3.5 \times 10^{0}$ & $4.0 \times 10^{-1}$ & $1.4 \times 10^{0}$ \\
\hline Localized Fire $(70,000 \mathrm{Ci})$ & $2.5 \times 10^{3}$ & $2.9 \times 10^{2}$ & $1.1 \times 10^{3}$ \\
\hline Earthquake + Fire $(385,000 \mathrm{Ci})$ & $1.4 \times 10^{4}$ & $1.6 \times 10^{3}$ & $5.8 \times 10^{3}$ \\
\hline $\begin{array}{l}\text { Transportation Accidents } \\
\text { Ground-level H-3 Release } \\
\text { (as tritium oxide) }\end{array}$ & $\begin{array}{l}\text { Onsite Dose, mrem } \\
100 \mathrm{~m} \text { ESE } \\
\mathrm{E} / \mathrm{Q}=3.4 \times 10^{-2} \\
\mathrm{~s} / \mathrm{m}^{3}\end{array}$ & $\begin{array}{l}\text { Offsite Dose, mrem } \\
580 \mathrm{~m} \text { ESE } \\
\mathrm{E} / \mathrm{Q}=1.7 \times 10^{-3} \\
\mathrm{~s} / \mathrm{m}^{3}\end{array}$ & \multirow[t]{3}{*}{ Not Applicable } \\
\hline $1 \mathrm{Ci}$ & $1.0 \times 10^{\circ}$ & $5.1 \times 10^{-2}$ & \\
\hline $3100 \mathrm{Ci}$ & $3.1 \times 10^{3}$ & $1.6 \times 10^{2}$ & \\
\hline
\end{tabular}

The dose for each accident scenario was then calculated by multiplying the dose per Ci tritium released by the estimated release for each type of event.

Table C.2 Consequences of Acute Tritium Releases at or near the Hanford Site 325 Building 


\section{C.5 References}

Brown, R. M., G. L. Ogram, and F.S. Spencer. 1990. "Oxidation and Dispersion of HT in the Environment: The August 1986 Field Experiment at Chalk River," Health Phys. 58(2):171-181.

International Commission on Radiological Protection (ICRP). 1977. Recommendations of the International Commission on Radiological Protection. ICRP Publication 26, Annals of the ICRP, Vol. 1, No. 3, Pergamon Press, Elmsford, New York.

International Commission on Radiological Protection (ICRP). 1979-1988. Limits for Intakes of Radionuclides by Workers. ICRP Publication 30, Parts 1-4 (and supplements), Annals of the ICRP Vol. 2 (No. 3/4), Vol.4 (No. 3/4), Vol. 6 No. 2/3), Vol. 8 (No. 4), and Vol. 19 (No.4), Pergamon Press, Elmsford, New York.

International Commission on Radiological Protection (ICRP). 1991. 1990 Recommendations of the International Commission on Radiological Protection. ICRP Publication 60, Annals of the ICRP Vol. 21 (No. 1-3), Pergamon Press, Oxford.

Johnson, A. B. Jr., T. J. Kabele, and W. E. Gurwell. 1976. Tritium Production from Ceramic Targets: A Summary of the Hanford Coproduct Program. BNWL-2097. Pacific Northwest Laboratory, Richland, Washington.

Napier, B. A., D. L. Strenge, R. A. Peloquin, and J. V. Ramsdell. 1988. GENII -The Hanford Environmental Radiation Dosimetry Software System. PNL-6584, Vol. 1 -Conceptual Representation, Vol. 2 - Users' Manual, Vol. 3 - Code Maintenance Manual. Pacific Northwest Laboratory, Richland, Washington.

Parks, B. S. 1992. User's Guide for CAP88-PC. Version 1.0. 402-B-92-001. Office of. Radiation Programs, U.S. Environmental Protection Agency, Las Vegas, Nevada.

Schreckhise, R. G., K. Rhoads, J. S. Davis, B. A. Napier, and J. V. Ramsdell. 1993. Recommended Environmental Dose Calculation Methods and Hanford-Specific Parameters. PNL-3777, Rev. 2. Pacific Northwest Laboratory, Richland Washington.

U.S. Department of Energy (DOE). 1988. Internal Dose Conversion Factors for Calculation of Dose to the Public. DOE/EH-0071, DOE Assistant Secretary for Environment, Safety, and Health, Washington, D.C.

U.S. Nuclear Regulatory Commission (NRC). 1977. Calculation of Annual Doses to Man from Routine Releases of Reactor Effluents for the Purpose of Evaluating Compliance with 10 CFR Part 50, Appendix I. Regulatory Guide 1.109, NRC Office of Standards Development, Washington, D.C. 



\section{APPENDIX D}

\section{TRANSPORTATION IMPACT ANALYSIS}

This appendix evaluates the impacts of both incident-free (routine) transport of radioactive materials in which the shipments reach their destinations without incident and the impacts of accidents involving the shipments. The consequences of the maximum credible transportation accident are also calculated. The approaches and data used to calculate these impacts are presented, as well as the shipping scenarios and characteristics of the radioactive shipments that are important to determining the radiological impacts. Nonradiological impacts are also calculated.

Section D.1 provides a description of the shipping scenarios and the characteristics of the shipments analyzed in this Appendix. Descriptions of the approach and computer codes used in this analysis are presented in Section D.2. Section D.3 presents the results of the transportation impact calculations.

\section{D.1 SHIPPING SCENARIOS AND SHIPMENT CHARACTERISTICS}

This section presents the shipping scenarios and shipment characteristics for each of the shipments required for the transport of unirradiated and irradiated tritium-producing burnable absorber rods (TPBARs). The information presented includes container and shipment capacities, shipment inventories, numbers of shipments, and route information.

The radionuclide inventories used in the analyses are presented in Table D.1. The data in the table represent the maximum bounding inventories of each radionuclide. The bounding inventories were used in analyzing both incident-free and accident impacts.

This analysis was based on the following assumptions:

- All overland transportation would be by truck.

- The 32 TPBARS would be shipped in one package to the Westinghouse fuel fabrication facility located in Columbia, South Carolina. This shipment would consist of nonradioactive materials only.

- One shipment containing two packages (two integrated fuel assemblies per package) would be used to ship the assembled fuel to the Watts Bar Nuclear Power Plant (WBNP), located near Chattanooga, Tennessee. This shipment would utilize a commercial carrier approved for low specific activity material shipments.

- Two to four shipments, each containing one or two TPBAR-LTAs, would be used to ship the irradiated TPBARs from the WBNP to the Hanford Site near Richland, Washington. All shipments would utilize an NRC-licensed Type B cask on exclusive use routes, and the number of shipments would depend on the capacity of the specific cask used. For exclusive use shipments, highway route controlled quantities are shipped on interstate highways or state-designated alternative routes (49CFR171-177). This was assumed for the shipments of the irradiated TPBARS due to the radionuclide inventories and sensitive nature of the shipments (i.e., tritium).

- Following disassembly of the TPBAR-LTAs at Hanford, all 32 TPBARs would be transported in a single shipment to ANL-W, near Idaho Falls, ID, for nondestructive evaluation (NDE). These 
shipments would also utilize an NRC-licensed Type B cask on exclusive use routes. Upon completion of the NDE, all 32 TPBARs would be returned to Hanford for post-irradiation examination (PIE).

- When PIE activities are completed, all 32 TPBARs and associated laboratory waste are assumed to be disposed of at the Hanford Site low level waste burial grounds in the 200 Areas. After the TPBARLTAs are disassembled, the hardware other than the TPBARs (designated non-target bearing components, or NTBCs) were assumed to be packaged and transported to the burial grounds in 4 shipments using a DOE-approved shipping container. Spent TPBARs and associated laboratory wastes are assumed to be transported in one additional shipment. 
Table D.1 Radionuclide Inventory

\begin{tabular}{|c|c|c|c|c|c|}
\hline Radionuclide & $\begin{array}{l}\text { Quantity per } \\
\text { TPBAR }^{(\mathbf{a})} \\
\text { (Ci) }\end{array}$ & $\begin{array}{l}\text { Quantity per } \\
\text { assembly } \\
\text { (Ci) }\end{array}$ & $\begin{array}{l}\text { Quantity per } \\
\text { shipping cask } \\
\text { (Ci) }\end{array}$ & $\begin{array}{c}\text { NTBC }^{(\mathrm{c})}: \\
\text { Quantity per solid } \\
\text { waste package } \\
\text { (Ci) }\end{array}$ & $\begin{array}{l}\text { Targets }^{(\mathrm{d})} \text { : } \\
\text { Quantity per } \\
\text { package } \\
\text { (Ci) }\end{array}$ \\
\hline $\mathrm{H}-3$ & $1.13 E+04$ & $9.28 \mathrm{E}+04$ & $1.81 E+05$ & 0 & $3.62 E+05$ \\
\hline $\mathrm{Cr}-51$ & $5.64 \mathrm{E}+00$ & $1.35 E+02$ & $2.71 E+02$ & $9.02 E+01$ & $1.80 \mathrm{E}+02$ \\
\hline Mn-54 & $1.41 E+01$ & $3.38 E+02$ & $6.77 \mathrm{E}+02$ & $2.26 \mathrm{E}+02$ & $4.51 \mathrm{E}+02$ \\
\hline $\mathrm{Fe}-55$ & $9.21 E+01$ & $2.21 E+03$ & $4.42 \mathrm{E}+03$ & $1.47 \mathrm{E}+03$ & $2.95 E+03$ \\
\hline $\mathrm{Fe}-59$ & $6.46 \mathrm{E}-01$ & $1.55 \mathrm{E}+01$ & $3.10 \mathrm{E}+01$ & $1.03 E+01$ & $2.07 E+01$ \\
\hline $\mathrm{Co}-58$ & $1.33 \mathrm{E}+01$ & $3.19 E+02$ & $6.38 \mathrm{E}+02$ & $2.13 E+02$ & $4.26 E+02$ \\
\hline $\mathrm{Co}-60$ & $3.03 E+01$ & $7.27 \mathrm{E}+02$ & $1.45 \mathrm{E}+03$ & $4.85 E+02$ & $9.70 \mathrm{E}+02$ \\
\hline $\mathrm{Ni}-63$ & $3.51 \mathrm{E}+00$ & $8.42 E+01$ & $1.68 \mathrm{E}+02$ & $5.62 \mathrm{E}+01$ & $1.12 \mathrm{E}+02$ \\
\hline $\mathrm{Zr}-95$ & $4.51 \mathrm{E}+00$ & $1.08 \mathrm{E}+02$ & $2.16 \mathrm{E}+02$ & $7.22 \mathrm{E}+01$ & $1.44 \mathrm{E}+02$ \\
\hline $\mathrm{Nb}-95$ & $8.89 E+00$ & $2.13 E+02$ & $4.27 E+02$ & $1.42 \mathrm{E}+02$ & $2.84 \mathrm{E}+02$ \\
\hline Mo-99 & $7.18 \mathrm{E}-18$ & $1.07 \mathrm{E}-16$ & $3.41 \mathrm{E}-16$ & $1.14 \mathrm{E}-16$ & $2.27 \mathrm{E}-16$ \\
\hline \multicolumn{6}{|c|}{$\begin{array}{l}\text { (a) Taken from TTQP-1-050, Conservative estimate for 180-day discharge } \\
\text { (b) Ci per shipping cask assuming } 2 \text { assemblies per cask } \\
\text { (c) NTBC - non-target-bearing components, Ci per waste package assuming } 1 \text { assembly per } \\
\text { waste package } \\
\text { (d) Ci per package assuming } 32 \text { target rods per shipment to HFEF or solid waste }\end{array}$} \\
\hline
\end{tabular}

\section{D.1.1 Transportation Route Information}

The transportation routes assumed for this analysis are shown in Table D.2. The information shown in Table D. 2 includes the number of shipments required, origin, and destination facilities. 
Table D.2. Transportation Routing Information

\begin{tabular}{|l|c|l|l|}
\hline \multicolumn{1}{|c|}{ Material Transported } & $\begin{array}{c}\text { No. of } \\
\text { Shipments }\end{array}$ & \multicolumn{1}{|c|}{ Origin } & \multicolumn{1}{|c|}{ Destination } \\
\hline Unirradiated TPBAR assemblies & $1^{(a)}$ & PNNL, Hanford, Washington & $\begin{array}{l}\text { WBNP, Chattanooga, } \\
\text { Tennessee }\end{array}$ \\
\hline Irradiated TPBAR assemblies & $2-4^{(b)}$ & WBNP, Chattanooga, Tennessee & $\begin{array}{l}\text { PNNL, Hanford, } \\
\text { Washington }\end{array}$ \\
\hline Irradiated TPBARs & $1^{(b)}$ & PNNL, Hanford, Washington & HFEF, Idaho Falls, Idaho \\
\hline Irradiated TPBARs & $1^{(b)}$ & HFEF, Idaho Falls, Idaho & $\begin{array}{l}\text { PNNL, Hanford, } \\
\text { Washington }\end{array}$ \\
\hline Irradiated TPBARs & $1^{(c)}$ & PNNL, Hanford, Washington & $\begin{array}{l}\text { Solid Waste, Hanford, } \\
\text { Washington }\end{array}$ \\
\hline $\begin{array}{l}\text { Non-target bearing components } \\
4^{(c)}\end{array}$ & PNNL, Hanford, Washington & $\begin{array}{l}\text { Solid Waste, Hanford, } \\
\text { Washington }\end{array}$ \\
\hline $\begin{array}{l}\text { Return shipment of empty cask } \\
1-3^{(a)}\end{array}$ & PNNL, Hanford, Washington & $\begin{array}{l}\text { WBNP, Chattanooga, } \\
\text { Tennessee }\end{array}$ \\
\hline $\begin{array}{l}\text { (a) Commercial routes used for analysis } \\
\text { (b) HM-164 routes used for analysis } \\
\text { (c) Onsite roadways }\end{array}$ & & \\
\hline
\end{tabular}

The transportation route information used in this analysis is shown in Table D.3. The information shown in Table D. 3 includes the shipping distances and population densities. These data are used to calculate transportation impacts and were developed using the HIGHWAY 3.3 (Johnson et al. 1993) computer code for truck shipments or were estimated using site maps. The population density data for shipments on the Hanford Site were developed using site maps and suburban population densities to represent occupied facilities and rural population densities for all other areas adjacent to the transport route. 
Table D.3. Summary of Transportation Analysis Information

\begin{tabular}{|c|c|c|c|c|c|c|}
\hline \multicolumn{2}{|c|}{ Material Transported } & \multirow{2}{*}{$\begin{array}{c}\text { No. of } \\
\text { Shipments }\end{array}$} & \multirow{2}{*}{$\begin{array}{c}\text { Shipment } \\
\text { distance (km } \\
\text { one-way) }\end{array}$} & \multicolumn{3}{|c|}{ Population Density, people/ $\mathrm{km}^{2}$ (a) } \\
\hline Origin & Destination & & & Rural & Suburban & Urban \\
\hline \multicolumn{7}{|c|}{ Unirradiated TPBAR assemblies ${ }^{(\mathbf{b})}$} \\
\hline PNNL & $\begin{array}{l}\text { Westinghouse, } \\
\text { Columbia, S.C. }\end{array}$ & 1 & 4282.3 & $\begin{array}{l}7.0 \\
(86.2) \\
\end{array}$ & $\begin{array}{l}333.3 \\
(12.7) \\
\end{array}$ & $\begin{array}{l}2071.8 \\
(1.1) \\
\end{array}$ \\
\hline $\begin{array}{l}\text { Westinghouse, } \\
\text { Columbia, S.C. }\end{array}$ & WBNP & 1 & 515.0 & $\begin{array}{l}14.0 \\
(71.2) \\
\end{array}$ & $\begin{array}{l}292.6 \\
(27.9) \\
\end{array}$ & $\begin{array}{l}1917.5 \\
(0.8) \\
\end{array}$ \\
\hline \multicolumn{7}{|c|}{ Irradiated TPBAR assemblies (c) } \\
\hline WBNP & PNNL & $2-4$ & 4045.8 & $\begin{array}{l}6.2 \\
(87.5) \\
\end{array}$ & $\begin{array}{l}349.2 \\
(11.3) \\
\end{array}$ & $\begin{array}{l}2174.7 \\
(1.2) \\
\end{array}$ \\
\hline \multicolumn{7}{|c|}{ Irradiated TPBARs } \\
\hline PNNL (c) & HFEF & 1 & 967.2 & $\begin{array}{l}5.8 \\
(91.6) \\
\end{array}$ & $\begin{array}{l}382.4 \\
(7.9) \\
\end{array}$ & $\begin{array}{l}1984.0 \\
(0.6) \\
\end{array}$ \\
\hline $\operatorname{HFEF}^{(c)}$ & PNNL & 1 & 967.2 & $\begin{array}{l}5.8 \\
(91.6) \\
\end{array}$ & $\begin{array}{l}382.4 \\
(7.9) \\
\end{array}$ & $\begin{array}{l}1984.0 \\
(0.6) \\
\end{array}$ \\
\hline $\mathrm{PNNL}^{(\mathrm{d})}$ & Solid Waste & 1 & 43.2 & $\begin{array}{l}2.4 \\
(97.1) \\
\end{array}$ & $\begin{array}{l}89.8 \\
(2.9) \\
\end{array}$ & NA \\
\hline \multicolumn{7}{|c|}{ Non-target bearing components } \\
\hline PNNL $^{(d)}$ & Solid Waste & 4 & 43.2 & $\begin{array}{l}2.4 \\
(97.1)\end{array}$ & $\begin{array}{r}89.8 \\
(2.9) \\
\end{array}$ & NA \\
\hline \multicolumn{7}{|c|}{ Empty shipping cask ${ }^{(b)}$} \\
\hline PNNL & WBNP & $1-3$ & 4282.3 & $\begin{array}{l}7.0 \\
(88.3)\end{array}$ & $\begin{array}{l}333.3 \\
(10.6)\end{array}$ & $\begin{array}{l}2071.8 \\
(1.1)\end{array}$ \\
\hline $\begin{array}{l}\text { (a) Values sho } \\
\text { (b) Commercia } \\
\text { (c) HM-164 ro } \\
\text { (d) Hanford Si }\end{array}$ & $\begin{array}{l}\text { in parenthesis in } \\
\text { outes used for an } \\
\text { tes used for analy } \\
\text { roadways }\end{array}$ & $\begin{array}{l}\text { icate percen } \\
\text { lysis }\end{array}$ & of total route & in each po & on zone. & \\
\hline
\end{tabular}




\section{D.2 ROUTINE AND ACCIDENT IMPACT ANALYSIS METHODS AND MODELS}

This section describes the methods used to estimate consequences of normal and accidental exposure of individuals or populations to radioactive materials. The RADTRAN 4 computer codes (Neuhauser and Kanipe 1992) were used to calculate the transportation impacts, and the GENII software package (Napier et al. 1988) was used to estimate the consequences to the maximum individuals.

The output from computer codes, as total effective dose equivalent (TEDE or dose) to the affected receptors, was then used to express the consequences in terms of potential latent cancer fatalities (LCF). Recommendations of the International Commission on Radiological Protection (ICRP 1991) for low dose, low dose rate radiological exposures were used to convert dose as TEDE to LCF. The conversion factor applied to adult workers (i.e., Hanford Site workers) was $4 \times 10^{-4} \mathrm{LCF} / \mathrm{rem}$ TEDE; and the conversion factor for the general population was $5 \times 10^{-4} \mathrm{LCF} / \mathrm{rem}$ TEDE. The general population was assumed to have a higher rate of cancer induction for a given radiation dose than healthy adult workers because of the presence of more sensitive individuals (e.g., children) in the general population.

Nonradiological incident-free and accident impacts were also evaluated. Nonradiological incident-free impacts consist of fatalities from fugitive emissions or pollutants emitted from the vehicles. Nonradiological accident impacts are the fatalities resulting from potential vehicular accidents involving the shipments. Neither of these two categories of impacts is related to the radiological characteristics of the cargo. Hand calculations were performed using unit-risk factors (fatalities per $\mathrm{km}$ of travel) to derive estimates of the nonradiological impacts. The nonradiological impacts were calculated by multiplying the unit risk factors by the total shipping distances for all of the shipments in each shipping option. Nonradiological unit risk factors for incident-free transport were taken from Neuhauser and Kanipe (1992).

\section{D.2.1 RADTRAN 4 Computer Code}

The RADTRAN 4 computer code (Neuhauser and Kanipe 1992) was used to perform the analyses of the radiological impacts of routine transport and the integrated population risks of accidents during transport of the irradiated TPBAR assemblies, TPBARs, and NTBCs. RADTRAN was developed by Sandia National Laboratories (SNL) to calculate the risks associated with the transportation of radioactive materials. The original code was written by SNL in 1977 in association with the preparation of NUREG-0170, Final Environmental Statement on the Transportation of Radioactive Material by Air and Other Modes (NRC 1977). The code has since been refined and expanded and is currently maintained by SNL under contract with DOE. 
The RADTRAN 4 computer code is organized into the following seven models (Neuhauser and Kanipe 1992):

- material model

- transportation model

- population distribution model

- health effects model

- accident severity and package release model

- meteorological dispersion model

- economic model.

The code uses the first three models to calculate the potential population dose from normal, incident-free transportation and the first six models to calculate the risk to the population from user-defined accident scenarios. The economic model is not used in this study.

\section{D.2.1.1 Material Model}

The material model defines the source as either a point source or as a line source. For exposure distances less than twice the package dimension, the source is conservatively assumed to be a line source. For all other cases, the source is modeled as a point source that emits radiation equally in all directions.

The material model also contains a library of 59 isotopes, each of which has 11 defining parameters used to calculate dose. The user can add isotopes not in the RADTRAN library by creating a data table in the input file consisting of eleven parameters.

\section{D.2.1.2 Transportation Model}

The transportation model allows the user to input descriptions of the transportation route. A transportation route may be divided into links or segments of the journey, with information for each link on population density, mode of travel (e.g., trailer truck), accident rate, vehicle speed, road type, vehicle density, and length. Alternatively, the transportation route also can be described by aggregate route data for rural, urban, and suburban areas. For this analysis, the aggregate route method was used for each potential origin-destination combination.

\section{D.2.1.3 Health Effects Model}

The health effects model in RADTRAN 4 is outdated and is replaced by hand calculations. The health effects are determined by multiplying the RADTRAN4 population dose (person-rem) by a conversion factor. 


\section{D.2.1.4 Accident Severity and Package Release Model}

Accident analysis in RADTRAN 4 is performed using the accident severity and package release model. The user can define up to 20 severity categories for three population densities (urban, suburban, and rural), each increasing in magnitude. Eight severity categories for SNF containers that are related to fire, puncture, crush, and immersion environments are defined in NUREG-0170 (NRC 1977). Various other studies have been performed for small packages (Clarke et al. 1976) and large packages (Dennis et al. 1978) that also can be used to generate severity categories. The accident scenarios are further defined by allowing the user to input release fractions and aerosol and respirable fractions for each severity category. These fractions are also a function of the physical-chemical properties of the materials being transported.

\section{D.2.1.5 Meteorological Dispersion Model}

RADTRAN 4 allows the user to choose two different methods for modeling the atmospheric transport of radionuclides after a potential accident: Pasquill atmospheric-stability category data or averaged timeintegrated concentrations. In this analysis, the dispersion of radionuclides after a potential accident is modeled by the use of time-integrated concentration values in downwind areas compiled from national averages by SNL.

\section{D.2.1.6 Incident-Free Transport}

The models described above are used by RADTRAN 4 to determine dose from incident-free transportation or risk from potential accidents. The public and worker doses calculated by RADTRAN 4 for incident-free transportation are dependent on the type of material being transported and the transportation index (TI) of the package or packages. The $T I$ is defined in 49 CFR $173.403(\mathrm{bb})$ as the highest package dose rate in millirem per hour at a distance of $1 \mathrm{~m}$ from the external surface of the package. Dose consequences are also dependent on the size of the package, which as indicated in the material model description, will determine whether the package is modeled as a point source or a line source for close-proximity exposures.

\section{D.2.1.7 Analysis of Potential Accidents}

The accident analysis performed in RADTRAN 4 calculates population doses for each accident severity category using six exposure pathway models: inhalation, resuspension, groundshine, cloudshine, ingestion, and direct exposure. This RADTRAN 4 analysis assumes that any contaminated area is either mitigated or public access is controlled so the dose via the ingestion pathway equals zero. The consequences calculated for each severity category are multiplied by the appropriate frequencies for accidents in each category and summed to give a total point estimate of risk for a radiological accident.

\section{D.2.2 GENII Description}

GENII (Napier et al. 1988), which is also referred to as the Hanford Environmental Dosimetry Software System, was developed by the Pacific Northwest National Laboratory to analyze radiological releases to the environment. GENII is composed of seven linked computer programs and their associated data libraries, including user interface programs, internal and external dose factor generators, and the environmental dosimetry programs. 
GENII is capable of:

- Calculating doses resulting from acute or chronic releases, including options for annual dose, committed dose, and accumulated dose

- Calculating doses from various exposure pathways evaluated, including those through direct exposure via water, soil, and air, as well as inhalation and ingestion pathways

- Acute and chronic elevated and ground level releases to air

- Acute and chronic releases to water

- Initial contamination of soil or surfaces

- Radionuclide decay.

The pathways considered in this analysis include inhalation, submersion, and external exposures due to ground contamination.

\section{D.3 RESULTS OF INCIDENT-FREE TRANSPORTATION IMPACT ANALYSIS}

This section discusses the radiological and non-radiological impacts to the truck crew and the public during incident-free or routine transportation activities. The key input parameters for the RADTRAN 4 computer code that were used to perform the incident-free transportation impact calculations are provided in Table D.4. Separate subsections are provided below for the results of the radiological and nonradiological impact calculations.

\section{D.3.1 Radiological Impacts of Incident-Free Transportation}

The radiological doses to the truck crew, onsite worker, and the public from transportation activities were calculated using RADTRAN 4 (see Section D.2). RADTRAN 4 uses a combination of meteorological, demographic, health physics, transportation, packaging, and material factors to analyze the radiological exposures from incident-free transport activities. The doses to the truck crew and the public were calculated on a per-shipment basis and for the entire campaign.

Table D.4 Incident-Free and Accident Analyses Input Parameters ${ }^{(2)}$

\begin{tabular}{|c|c|}
\hline Parameter & Value \\
\hline Fraction of travel time per population zone & See Table D..$^{(b)}$ \\
\hline $\begin{array}{r}\text { Radiation dose rate }(\mathrm{mrem} / \mathrm{hr}) \text { at } 1 \mathrm{~m} \text { : Type B shipping cask } \\
\text { solid waste container }\end{array}$ & $\begin{array}{l}1,000^{\circ} \\
200^{(d)}\end{array}$ \\
\hline Number of crewmen & 2 \\
\hline Distance from source to crew, meters & 10 \\
\hline Stop time per kilometer, hours per kilometer & 0.011 \\
\hline
\end{tabular}




\begin{tabular}{|l|c|}
\hline Persons exposed while stopped & 50 \\
\hline Average exposure distance while stopped, meters & 20 \\
\hline Number of people per vehicle & 2 \\
\hline Traffic count in rural zone, one-way vehicles per hour & 470 \\
\hline Traffic count in suburban zone, one-way vehicles per hour & 780 \\
\hline Traffic count in urban zone, one-way vehicles per hour & 2,800 \\
\hline Total shipping distance, kilometers & See Table D.3 ${ }^{(b)}$ \\
\hline Population densities by population zone & See Table D.3 \\
\hline $\begin{array}{l}\text { (a) RADTRAN } 4 \text { default values except where indicated } \\
\text { (b) Values are shipment dependent } \\
\text { O Regulatory maximum for a Type B package (10CFR71), RADTRAN 4 } \\
\text { automatically adjusts for maximum allowable in crew compartment } \\
\text { (d) Hanford Site waste acceptance criteria }\end{array}$ \\
\hline
\end{tabular}

No radiological impacts are associated with transporting the unirradiated TPBARs to the Westinghouse fuel assembly facility or with transporting the assembled fuel to WBNP. It is also assumed that there are no radiological impacts associated with transporting the empty shipping cask from PNNL to WBNP for reloading. Therefore, the potential routine radiological impacts have been estimated for shipments from WBNP to PNNL, PNNL to HFEF, from HFEF to PNNL, and from PNNL to the Hanford Site solid waste facility.

The potential radiological impacts, based on the radionuclide inventories shown in Table D.1, have been calculated using the RADTRAN 4 computer code (Neuhauser and Kanipe 1994) and the assumptions provided in Tables D.3 and D.4. The potential radiological impacts involve in-transit doses to the public or, where appropriate, Hanford Site workers from radiation emitted from the shipping cask and doses to the transport workers in the vicinity of the shipment during cask-handling activities, e.g., loading or unloading the cask on or off the truck trailer. In-transit doses have been estimated for the truck drivers; the general public, including people at truck stops or those living or working adjacent to the transport route; and nearby travelers (moving in the same and opposite directions). The results of the analysis are shown in Table D.5.

Table D.5. Radiological Impacts of Routine or Incident-Free Transportation

\begin{tabular}{|c|c|c|c|c|}
\hline \multicolumn{2}{|c|}{} & \multicolumn{2}{c|}{$\begin{array}{c}\text { Radiological Impacts } \\
\text { (person-rem) }\end{array}$} & $\begin{array}{c}\text { Health Effects } \\
\text { (LCFs) }\end{array}$ \\
\hline Origin & Destination & Truck Crew & Public & Public \\
\hline \multicolumn{5}{|c|}{ Irradiated TPBAR assemblies } \\
\hline WBNP & PNNL & & & None (7.5E-04) \\
& 2 shipments & 0.40 & 1.5 & None (1.5E-03) \\
& 4 shipments & 0.80 & 3.0 &
\end{tabular}




\begin{tabular}{|l|l|c|c|c|}
\hline \multicolumn{7}{|c|}{ Irradiated TPBARs } \\
\hline PNNL & HFEF & 0.046 & 0.18 & $\begin{array}{c}\text { None } \\
(9.0 \mathrm{E}-05)\end{array}$ \\
\hline HFEF & PNNL & 0.046 & 0.18 & $\begin{array}{c}\text { None } \\
(9.0 \mathrm{E}-05)\end{array}$ \\
\hline PNNL & Solid Waste & 0.0020 & 0.0024 & $\begin{array}{c}\text { None } \\
(9.6 \mathrm{E}-07)\end{array}$ \\
\hline \multicolumn{5}{|c|}{ Non-target bearing components } \\
\hline PNNL & Solid Waste & 0.0080 & 0.0094 & $\begin{array}{c}\text { None } \\
(3.8 \mathrm{E}-06)\end{array}$ \\
\hline
\end{tabular}

The total collective doses to the crew and members of the public for all shipments are 0.50 person-rem and 1.9 person-rem, respectively if 2 shipments are made between WBNP and PNNL; the corresponding estimates for 4 shipments would be 0.9 person-rem to the crew and 3.4 person-rem to the public (see Table D.5). To place these impacts in perspective, the estimated dose the public and Hanford Site workers might receive can be compared with the natural background dose they receive. The natural background dose was calculated for the exposed population along the route for one shipment from WBNP to PNNL. The exposed population was determined to be unshielded individuals within $30 \mathrm{~m}$ on both sides of the route. Thus, the total area involved is the product of the total shipping distance times $60 \mathrm{~m}$. The number of persons in this area along the route was determined by multiplying the total affected area by the sum of the products of the travel fractions and population densities in rural, suburban and urban zones (see Table D.3), as shown below.

$$
\begin{array}{ll}
\text { Total shipping distance } & =2514 \mathrm{~km} \\
\text { Exposure area, } \mathrm{A} & =(2514 \mathrm{~km})(0.06 \mathrm{~km})=151 \mathrm{~km}^{2} \\
\text { Total exposed population } & =\mathrm{A}[(\text { travel fraction })(\text { population density })] \\
& =151 \mathrm{~km}^{2}[(0.875)(6.2)+(0.113)(349.2)+(0.012)(2174.7)] \\
& =10,700 \text { persons }
\end{array}
$$

According to the National Council on Radiation Protection (NCRP 1987), the average annual natural background exposure in the United States is $\mathbf{3 0 0}$ mrem per year per person. The resulting average annual radiation dose to the exposed population (i.e., 10,700 persons) for the shipment from WBNP to PNNL is estimated to be 3,200 person-rem per year or 0.37 person-rem per hour. Based on the HIGHWAY 3.3 computer runs, the shipment from WBNP to PNNL will take approximately 2.25 days or 54 hours; therefore, the estimated dose from natural background radiation for a 54- hour period is 20 person-rem to the exposed population-greater than 13 times the estimated dose to the public or 1.5 person-rem per shipment (see Table D.5).

\section{D.3.2 Non-Radiological Impacts of Incident-Free Transportation Activities}


Impacts to the public from non-radiological causes were also evaluated. These impacts included fatalities resulting from fugitive emissions or pollutants emitted from the vehicles during normal transportation. Based on Rao et al. (1982), the types of pollutants that could impact the public are sulfur oxides $\left(\mathrm{SO}_{\mathrm{x}}\right)$, particulates, nitrogen oxides $\left(\mathrm{NO}_{\mathrm{x}}\right.$ ), carbon monoxide $(\mathrm{CO})$, hydrocarbons $(\mathrm{HC})$, and photochemical oxidants $\left(\mathrm{O}_{x}\right)$. Of these pollutants, Rao et al. (1982) determined that the majority of the health effects are due to $\mathrm{SO}_{\mathrm{x}}$ and the particulates. Rao et al. (1982) developed unit risk factors (fatalities per kilometer) for truck shipments traveling in urban population zones. The unit risk factor is $1.0 \mathrm{E}-07$ fatalities $/ \mathrm{km}$ for truck shipments.

The nonradiological incident-free impacts were calculated based on the travel distances shown in Table D.3. The results are shown in Table D.6. No nonradiological impacts are associated with this activity. That is, the total estimated number of fatalities is less than 4.2E-05.

Table D.6. Nonradiological Impacts of Routine or Incident-Free Transportation

\begin{tabular}{|c|c|c|c|}
\hline \multicolumn{2}{|c|}{ Material Transported } & \multirow{2}{*}{\multicolumn{2}{|c|}{$\begin{array}{l}\text { Nonradiological Impacts } \\
\text { of fugitive emissions } \\
\text { (fatalities) }\end{array}$}} \\
\hline Origin & Destination & & \\
\hline \multicolumn{4}{|c|}{ Unirradiated TPBAR assemblies } \\
\hline PNNL & WBNP & None & $(5.9 \mathrm{E}-06)$ \\
\hline \multicolumn{4}{|c|}{ Irradiated TPBAR assemblies } \\
\hline WBNP & $\begin{array}{l}\text { PNNL } \\
2 \text { shipments } \\
4 \text { shipments }\end{array}$ & $\begin{array}{l}\text { None } \\
\text { None } \\
\end{array}$ & $\begin{array}{l}(1.1 \mathrm{E}-05) \\
(2.2 \mathrm{E}-05) \\
\end{array}$ \\
\hline \multicolumn{4}{|c|}{ Irradiated TPBARs } \\
\hline PNNL & HFEF & None & $(5.3 \mathrm{E}-07)$ \\
\hline HFEF & PNNL & None & $(5.3 \mathrm{E}-07)$ \\
\hline PNNL & Solid Waste & $\mathrm{NA}^{(0)}$ & \\
\hline \multicolumn{4}{|c|}{ Non-target bearing components } \\
\hline PNNL & Solid Waste & $N_{A}^{(a)}$ & \\
\hline \multicolumn{4}{|c|}{ Empty shipping cask for reloading } \\
\hline PNNL & $\begin{array}{l}\text { WBNP } \\
1 \text { shipment } \\
3 \text { shipments }\end{array}$ & $\begin{array}{l}\text { None } \\
\text { None }\end{array}$ & $\begin{array}{l}(4.2 \mathrm{E}-06) \\
(1.3 \mathrm{E}-05) \\
\end{array}$ \\
\hline
\end{tabular}

\section{D.4 ANALYSIS OF TRANSPORTATION ACCIDENTS}


This section discusses the potential radiological and non-radiological impacts of transportation accidents for each part of the transportation route discussed in Section D.1. Radiological accident impacts to the collective population (public) were calculated using the RADTRAN 4 computer code (Neuhauser and Kanipe 1992). The radiological impacts to the maximum onsite and offsite individuals, were calculated using GENII (Napier 1988).

\section{D.4.1 Radiological Impacts to the Public from Transportation Accidents}

This section describes the analyses performed to assess radiological impacts to the public and the maximum individuals from transportation accidents.

The transportation impacts are expressed as maximum individual doses or as integrated population risks. To determine the integrated population risks, the expected consequences of an accident were multiplied by the accident frequency, summed over all possible accidents, and then integrated over the entire shipping campaign. The potential impacts or consequences to the population from transportation accidents were expressed in terms of radiological dose and latent cancer fatalities.

Accident impacts can result from breaches in the shipping cask or damage to the cask shielding; however, the frequencies of occurrence of transportation accidents that would release significant quantities of radioactive material are relatively small. The shipping casks are designed to withstand specified transportation accident conditions (i.e., the shipping casks for all the materials shipped in this analysis were assumed to meet the Type B packaging requirements specified in 49 CFR 173 and 10 CFR 71); therefore, only a relatively small fraction of accidents involve conditions that are severe enough to result in a release of radioactive materials.

If the material were released to the environment, it would be dispersed and diluted by weather action, and a small amount would be deposited on the ground through plume depletion. Access to the area adjacent to the transportation accident would be controlled by emergency response personnel until the area could be remediated and the radiation monitoring personnel had declared the area safe.

The RADTRAN 4 computer code was used to calculate the radiological risk of transportation accidents involving radioactive material shipments. The RADTRAN 4 methodology was summarized previously. For further details, refer to the discussions presented by RADTRAN III (Madsen et al. 1986) and RADTRAN 4: Volume 2 - Technical Manual (Neuhauser and Kanipe 1992).

The RADTRAN 4 computer code calculates potential accident transportation risk impacts using five major categories of input data : 1) accident frequency, 2) release quantities, 3) atmospheric dispersion parameters, 4) population distribution parameters, and 5) human uptake and dosimetry models. Accident frequency and release quantities are discussed below; the remaining parameters were discussed in Section D.2.1.

To calculate the frequency of a severe accident, an overall accident rate (accidents per truck-km) is multiplied by the conditional probability that an accident would involve mechanical and/or thermal conditions that are severe enough to result in container failure and subsequent release of radioactive material.

For this analysis, the six shipment-specific severity categories and conditional probabilities identified in DOE (1996) were used to model cask failure. The conditional probability for a given severity category is 
defined as the fraction of accidents that would fall into that severity category if an accident were to occur. Severity category 1 was defined as encompassing all accidents within the Type B package envelope that would not be severe enough to result in failure of the shipping cask (i.e., accidents with zero release). The higher categories (2-6) were defined to include more severe accidents that might lead to a release of radioactive material. The conditional probabilities of the various severity categories that were used in this analysis are shown in Table D.7.

Table D.7. Severity Category Conditional Probabilities (DOE 1995)

\begin{tabular}{|l|c|c|c|c|c|c|}
\hline \multirow{2}{*}{ Mode/ Truck } & \multicolumn{6}{|c|}{ Conditional Probability by Severity Category } \\
\cline { 2 - 7 } & 1 & 2 & 3 & 4 & 5 & 6 \\
\hline Rural & 0.462 & 0.302 & 0.176 & 0.0403 & 0.0183 & $6.84 \mathrm{E}-04$ \\
\hline Suburban & 0.436 & 0.285 & 0.221 & 0.0506 & $8.38 \mathrm{E}-03$ & $7.31 \mathrm{E}-05$ \\
\hline Urban & 0.583 & 0.382 & 0.0278 & $6.36 \mathrm{E}-3$ & $8.88 \mathrm{E}-04$ & $1.22 \mathrm{E}-05$ \\
\hline
\end{tabular}

Release fractions are used to determine the quantity of radioactive material released to the environment as a result of an accident. The quantity of material released is a function of the severity of the accident (i.e., thermal and mechanical conditions produced in the accident), the response of the shipping container to these conditions, and the physical and chemical properties of the material being shipped. However, not all of the material released as a result of the accident is respirable and results in impacts to an individual. A fraction of the material released can be suspended in a plume and inhaled by an individual. The release fractions used in this analysis are shown in Table D.8. The fraction of the material released and suspended in plume (Aerosol) that can be inhaled by an individual (Respirable) is shown in Table D.9.

Table D.8. Release Fraction by Material and Severity Category

\begin{tabular}{|l|c|c|c|c|c|c|}
\hline \multirow{2}{*}{$\begin{array}{l}\text { TPBAR } \\
\text { Assembly } \\
\text { Component }\end{array}$} & 1 & 2 & 3 & 4 & 5 & 6 \\
\cline { 2 - 7 } & 0 & 0.0099 & 0.033 & 0.39 & 0.33 & 0.63 \\
\hline H-3 (a) & 0 & $3.0 \mathrm{E}-10$ & $1.0 \mathrm{E}-09$ & $1.0 \mathrm{E}-08$ & $1.0 \mathrm{E}-08$ & $1.0 \mathrm{E}-07$ \\
\hline NTBC & $(a)$ & \multicolumn{6}{|c|}{ Release Fraction by Severity Category } \\
\hline
\end{tabular}

Table D.9. Aerosol and Respirable Fractions by Material and Severity Category

\begin{tabular}{|l|c|c|c|c|c|c|}
\hline \multirow{2}{*}{$\begin{array}{l}\text { TPBAR } \\
\text { assembly } \\
\text { component }\end{array}$} & \multicolumn{6}{|c|}{ Aerosol and respirable fractions by severity category ${ }^{(2)}$} \\
\cline { 2 - 7 } & 1 & 2 & 3 & 4 & 5 & 6 \\
\hline $\mathrm{H}-3^{(\mathrm{b})}$ & $\mathrm{A}=0$ & $\mathrm{~A}=1$ & $\mathrm{~A}=1$ & $\mathrm{~A}=1$ & $\mathrm{~A}=1$ & $\mathrm{~A}=1$ \\
& $\mathrm{R}=0$ & $\mathrm{R}=1$ & $\mathrm{R}=1$ & $\mathrm{R}=1$ & $\mathrm{R}=1$ & $\mathrm{R}=1$ \\
\hline
\end{tabular}




\begin{tabular}{|c|c|c|c|c|c|c|}
\hline NTBC $C^{(0)}$ & $\begin{array}{l}A=0 \\
R=0\end{array}$ & $\begin{array}{l}A=0.01 \\
R=0.05\end{array}$ & $\begin{array}{l}A=0.01 \\
R=0.05\end{array}$ & $\begin{array}{l}A=0.01 \\
R=0.05\end{array}$ & $\begin{array}{l}A=0.01 \\
R=0.05\end{array}$ & $\begin{array}{l}A=0.01 \\
R=0.05\end{array}$ \\
\hline $\begin{array}{l}\text { (a) } A=f \\
\text { (b) Takes } \\
\text { as loc }\end{array}$ & $\begin{array}{l}\text { at is } \\
\text { euhal } \\
\text { s. }\end{array}$ & al. (199 & 3 cha & $\begin{array}{l}\text { able } \\
\text { d as a }\end{array}$ & nd NTE & acterized \\
\hline
\end{tabular}

The input data used to calculate the radiological dose to the public (i.e., population densities, travel times, and distances) were the same as the inputs used to calculate the incident-free dose to the population and are shown in Tables D.3 and D.4. The radiological inventory used in the accident analysis was shown in Table D.1. The accident frequency used in the analysis was based on a review of local or state-specific accident data (Saricks and Kvitek 1994). The Hanford Site accident data (or rates expressed as accidents $/ \mathrm{km}$ ) used in this analysis were taken from Bergsman et al. (1995) and are recommended for the Hanford Site. The accident rate used for truck shipments is $8.86 \mathrm{E}-08$ accidents $/ \mathrm{km}(5.50 \mathrm{E}-08$ accidents/mi).

Table D.10 presents the expected consequences for each transportation mode by waste type and destination. As shown in Table D.10, there are no impacts to the public (i.e., LCFs are less than 3.3E-04).

Table D.10. Radiological Impacts from Transportation Accidents

\begin{tabular}{|l|c|c|c|}
\hline \multicolumn{2}{|c|}{ Material Transported } & $\begin{array}{c}\text { Radiological } \\
\text { Impacts } \\
\text { (person-rem) }\end{array}$ & $\begin{array}{c}\text { Health Effects } \\
\text { (LCFs) }\end{array}$ \\
\hline Origin & Destination & Public & Public \\
\hline \multicolumn{4}{|c|}{ Irradiated TPBAR assemblies } \\
\hline WBNP & $\begin{array}{c}\text { PNNL } \\
\text { 2 shipments } \\
\text { 4 shipments }\end{array}$ & 0.35 & None (1.8E-04) \\
Irradiated TPBARs & None (3.0E-04) \\
\hline PNNL & HFEF & 0.030 & None (1.5E-05) \\
\hline HFEF & PNNL & 0.030 & None (1.5E-05) \\
\hline PNNL & Solid Waste & 0.00016 & None (6.4E-08) \\
\hline \multicolumn{4}{|c|}{ Non-target bearing components } \\
\hline PNNL & Solid Waste & $1.0 \mathrm{E}-11$ & None (4.0E-15) \\
\hline
\end{tabular}

\section{D.4.2 Radiological Impacts to Maximum-Exposed Individuals}

The consequences of a maximum credible accident to an individual were evaluated for shipments between the Hanford Site and ANL-W. Of the shipments evaluated, this leg would produce the greatest potential 
consequences because all 32 irradiated TPBARs could be involved. The receptor is assumed to be located at a distance of $100 \mathrm{~m}$ from the release if the accident occurs outside the boundaries of a DOE facility, or at the site boundary if the accident occurs onsite. Radiological doses were calculated for maximally exposed individuals near the PNNL 325 Building, either $100 \mathrm{~m}$ from the release point (the onsite individual), or at a distance of $580 \mathrm{~m}$ (the site boundary). For this bounding analysis, the maximum individuals were assumed to be located east-southeast of the release, which is the direction in which maximum consequences are obtained. These receptors were also presumed to bound the consequences of accidents that might take place within the INEEL site boundary or at offsite locations. The radionuclide inventory used in this analysis is shown in Table D.1. However, because tritium accounts for greater than $99 \%$ of the dose, only tritium releases are discussed in detail.

The bounding accident evaluated for transportation involves an impact severe enough to breach the shipping container and damage the TPBARs. Only free gaseous tritium within the TPBARs is assumed to be released in this event. Consistent with the evaluation for facility accidents (see Appendix C, Section C.3.1), the free tritium inventory in a single TPBAR amounts to an equivalent release of $96 \mathrm{Ci}$ as tritium oxide. Therefore, if all 32 TPBARs were damaged, the maximum release of tritium oxide would amount to about $3100 \mathrm{Ci}$. The radiological impacts of this release to the maximum individuals were calculated using GENII (Napier et al. 1988), and the results are presented in Table D.11 (see also Appendix C, Table C.2).

The estimated frequency of this accident is less than $2 \times 10^{-5}$ based on a round-trip transport distance of $1200 \mathrm{mi}$ between ANL-W and Hanford (Table D.3), an accident rate of $2.3 \times 10^{-7} / \mathrm{mi}$, and a conditional frequency of less than $6 \times 10^{-2}$ for accidents of severity category 4 or greater (Table D.7). Accidents of lesser severity would release substantially less than the total free tritium inventory in the TPBARs (Table D.8), whereas accidents involving sufficiently high thermal and mechanical stress to release $100 \%$ of the tritium would be considered incredible (i.e., they have an expected frequency less than $1 \times 10^{-7}$ ).

Table D.11. Dose to Maximally Exposed Individuals

\begin{tabular}{|c|c|c|}
\hline $\begin{array}{c}\text { Maximum } \\
\text { Individual }\end{array}$ & $\begin{array}{c}\text { Distance from } \\
\text { Release }\end{array}$ & $\begin{array}{c}\text { Total Effective } \\
\text { Dose Equivalent } \\
\text { (mrem) }\end{array}$ \\
\hline Public/Onsite & $100 \mathrm{~m}$ & $3.1 \times 10^{3}$ \\
\hline Offsite & $580 \mathrm{~m}$ & $1.6 \times 10^{2}$ \\
\hline
\end{tabular}

\section{D.4.3 Non-Radiological Impacts due to Transportation Accidents}

This section describes the analyses performed to assess non-radiological impacts to the public and Hanford Site workers. The non-radiological impacts associated with the transportation of the tritium lead test assemblies are assumed to be comparable to the impacts associated with general transportation activities in the United States. To calculate non-radiological impacts or fatalities, a unit risk factor (i.e. fatalities per $\mathrm{km}$ or fatalities per mi, developed for specific population zones or density) is multiplied by the total 
shipment distance (i.e., total distance per campaign). The fatalities are due to vehicular impacts with solid objects, rollovers, or collisions. Therefore, unit risk factors are required for crew members and the public, i.e., individuals on or immediately adjacent to roadways.

The unit risk factors applied to determine non-radiological impacts to the public (i.e., persons not on the Hanford Site) are taken from Saricks and Kvitek (1994). These factors are developed for specific population densities and are expressed as fatalities per $\mathrm{km}$ traveled. The unit risk factor used in this analysis for Hanford Site shipments, taken from Daling and Harris (1994), was 5.3E-08 fatalities/km for the public.

Results are obtained for each alternative by multiplying the unit risk factors by the appropriate total shipping distances for each alternative. It has been assumed that an accident that results in public or Hanford Site worker fatalities will also be fatal to the truck crew. The results of this analysis are shown in Table D.12 for all transportation modes, waste types, and destinations.

Table D.12. Non-Radiological Impacts due to Transportation Accidents

\begin{tabular}{|c|c|c|}
\hline \multicolumn{2}{|c|}{ Material Transported } & \multirow{2}{*}{$\begin{array}{c}\text { Non-radiological Impacts } \\
\text { (fatalities) }\end{array}$} \\
\hline Origin & Destination & \\
\hline \multicolumn{3}{|c|}{ Unirradiated TPBAR assemblies } \\
\hline PNNL & WBNP & None $(9.0 \mathrm{E}-05)$ \\
\hline \multicolumn{3}{|c|}{ Irradiated TPBAR assemblies } \\
\hline WBNP & $\begin{array}{l}\text { PNNL } \\
2 \text { shipments } \\
4 \text { shipments }\end{array}$ & $\begin{array}{l}\text { None }(1.4 E-04) \\
\text { None }(2.8 E-04)\end{array}$ \\
\hline \multicolumn{3}{|c|}{ Irradiated TPBARs } \\
\hline PNNL & HFEF & None $(1.6 \mathrm{E}-05)$ \\
\hline HFEF & PNNL & None $(1.6 E-05)$ \\
\hline PNNL & Solid Waste & None $(1.9 \mathrm{E}-06)$ \\
\hline \multicolumn{3}{|c|}{ Non-target bearing components } \\
\hline PNNL & Solid Waste & None $(9.2 \mathrm{E}-06)$ \\
\hline \multicolumn{3}{|c|}{ Empty shipping cask for reloading } \\
\hline PNNL & $\begin{array}{l}\text { WBNP } \\
1 \text { shipment } \\
3 \text { shipments }\end{array}$ & $\begin{array}{l}\text { None }(6.4 \mathrm{E}-05) \\
\text { None }(1.9 \mathrm{E}-04)\end{array}$ \\
\hline
\end{tabular}




\section{D.5 References}

10 CFR 71. 1993. U.S. Nuclear Regulatory Commission, "Packaging and Transportation of Radioactive Material." U.S. Code of Federal Regulations.

49 CFR 173. 1993. U.S. Department of Transportation, "Shippers - General Requirements for Shipments and Packages." U.S. Code of Federal Regulations.

Bergsman, K.E, T.B Bergman, D.W. Bergmann, G.E. Costley, M.T. Jansky, M. Kummerer, R.L. McCormack, M.J. Monthey, A.N. Praga, I.K. Ullah, W.L. Willis, and A.G. Hosler. 1995. K Basin Environmental Impact Statement Technical Input. WHC-SD-SNF-T1-013, Rev. 0. Westinghouse Hanford Company, Richland, Washington.

Clarke, R. K., J. T. Foley, W. F. Hartman, and D. W. Larson, 1976, Severities of Transportation Accidents, Volume 1 - Summary. SLA-74-001, Sandia National Laboratories, Albuquerque, New Mexico.

Daling, P. M. and M. S. Harris, 1994, Transportation Impact Analysis for Shipment of Irradiated NReactor Fuel and Associated Materials, PNL-10249, Pacific Northwest Laboratory, Richland, Washington.

Dennis, A. W., J. T. Foley, W. F. Hartman, and D. W. Larson, 1978, Severities of Transportation Accidents Involving Large Packages. SAND77-0001, Sandia National Laboratories, Albuquerque, New Mexico.

International Commission on Radiological Protection (ICRP). 1991. 1990 Recommendations of the International Commission on Radiological Protection. ICRP Publication 60, Pergamon Press, Oxford.

Johnson, P. E., D. S. Joy, D. B. Clarke, and J. M. Jacobi. 1993. HIGHWAY 3.3, An Enhanced Highway Routing Model: Program Description, Methodology, and Revised User's Manual. ORNL/TM-12124. Oak Ridge National Laboratory, Oak Ridge, Tennessee.

Madsen, M. M., J. M. Taylor, R. M. Ostmeyer, and P. C. Reardon. 1986. RADTRAN III. SAND84-0036. Sandia National Laboratories, Albuquerque, New Mexico.

Napier, B. A., D. L. Strenge, R. A. Peloquin, and J. V. Ramsdell. 1988. GENII-The Hanford Environmental Radiation Dosimetry Software System. PNL-6584, Vol. 1 -Conceptual Representation, Vol. 2 - Users' Manual, Vol. 3 - Code Maintenance Manual. Pacific Northwest Laboratory, Richland, Washington.

Neuhauser, K. S. and F. L. Kanipe. 1992. RADTRAN 4: Volume 3 -- User Guide. SAND89-2370. Sandia National Laboratories, Albuquerque, New Mexico.

Rao, R.K., E. L. Wilmot, and R. E. Luna. 1982. Non-Radiological Impacts of Transporting Radioactive Material. SAND81-1703. Sandia National Laboratories, Albuquerque, New Mexico.

Saricks, C. and T. Kvitek. 1994. Longitudinal Review of State-Level Accident Statistics for Carriers of Interstate Freight. ANL/ESD/TM-68. Argonne National Laboratory, Argonne, Illinois. 
U.S. Department of Energy (DOE). 1995. Department of Energy Programmatic Spent Nuclear Fuel Management and Idaho National Engineering Laboratory Environmental Restoration and Waste Management Programs Final Environment Impact Statement. DOE/EIS-0203-F. U.S. Department of Energy, Washington, D.C.

U.S. Nuclear Regulatory Commission (NRC). 1977. Final Environmental Impact Statement on the Transportation of Radioactive Material by Air and Other Modes. NUREG-0170. Washington D.C. 



\section{STATE OF WASHINGTON \\ DEPARTMENT OF ECOLOGY \\ P.O. Box 47600 - Olympia, Washington 98504-7600 \\ (360) 407-6000 • TDD Only (Hearing Impaired) (360) 407.6006}

June 25, 1997

Mr. Paul F.X. Dunigan Jr.

U.S. Dept. of Energy

PO Box 550

Richland WA 99352

Dear Mr. Dunigan:

Thank you for the opportunity to comment on the draft environmental assessment for Lead Test Assembly Irradiation and Analysis for the Watts Bar Nuclear Plant, Tennessee; and Hanford Site, Richland, Washington (DOE/EA-1210). We have reviewed the document and have the following comments.

Post irradiation examination and nondestructive evaluation activities conducted at Hanford's 325 facility should be planned and executed in a manner which fully supports required cleanup and compliance work and associated schedules under the Hanford Federal Facility Agreement and Consent Order.

Documentation should be forwarded to appropriate Ecology project managers for any wastes generated for storage, treatment, or disposal at Hanford facilities, containing identification, characterization, and plans for management.

If you have any questions, please call Mr. Roger Stanley with our Nuclear Waste program at (360) $407-7108$.

Sincerely,

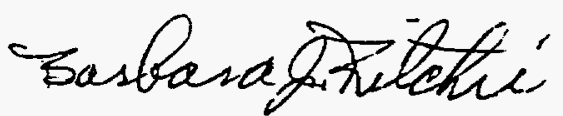

Barbara J. Ritchie

Environmental Review Section

BJR:ri

97-3847

cc: Ron Effland, Kennewick Roger Stanley, Nuc Waste

Geoff Tallent, Nuc Waste

RECEIVED

JUL 011997

DOE-RL/RLCC 

Ms. Barbara Ritchie

Environmental Review Section

State of Washington

Department of Ecology

P. 0. Box 47600

oiympia. Washington 98504-7600

Dear Ms. Ritchie:

RESPONSE TO COMMENTS ON THE DRAFT ENVIRONMENTAL ASSESSMENT FOR THE LEAD TEST ASSEMBLY IRRADIATION AND ANALYSIS

The U.S. Department of Energy. Richland Operations Office received your letter, dated June 25. 1997. providing comments on the draft environmental. assessment for the Lead Test Assembly Irradiation and Analysis for the Watts Bar Nuclear Plant. Tennessee: and Hanford Site, Richland. Washington (DOE/EA1210). Thank you for your interest in this project and for the comments provided in your letter.

In response to your comments, post irradiation examination and nondestructive evaluation activities conducted at the 325 Building will be planned and executed in a manner which fully supports required cleanup and compliance work and associated schedules under the Hanford Federal Facility Agreement and Consent Order.

In addition, documentation will be forwarded to appropriate Ecology project managers for any wastes generated for storage, treatment, or disposal at Hanford facilities in accordance with existing procedures.

If you have any questions, please contact me on 376-6667 or Julie Turner. NEPA Document Manager, on 372-4015.

Sincerely.

STP:JKT

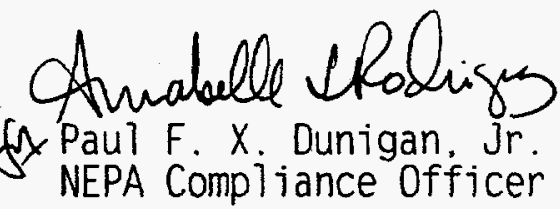

CC: C. M. Borgstrom, EH-42

S. M. Sohinki, DP-62 

STATE OF TENNESSEE

DEPARTMENT OF ENVIRONMENT AND CONSERVATION

DOE OVERSIGHT DIVISION

761 EMORY VALLEY ROAD.

OAK AIDGE, TENNESSEE 37830-7072

June 27, 1997

Paul F. X. Dunigan, Jr., NEPA Compliance Of

US Department of Energy

Richland Operations. Office

PO Box 550

Richland Washington 99352

Dear Mr. Dunigan

Document Review - Draft Environmental Assessment: "Lead Test Assembly Irradiation and Analysis Watts Bar Nuclear Plant, Tennessee and Hanford Site, Richland, Washington," DOE/EA-1210, June 1997

The Tennessee Department of Environment and Conservation, DOE Oversight Division (TDEC/DOE-O) has received the above Draft Environmental Assessment (EA). The Subject EA was reviewed in accordance with the requirements of the National Environmental Policy Act (NEPA) and associated implementing regulations 40 CFR 1500 1508 and 10 CFR 1021 as implemented.

If you have any questions regarding the Division's review, please contact Dale Rector at (423) 481-0995.

Sincerely

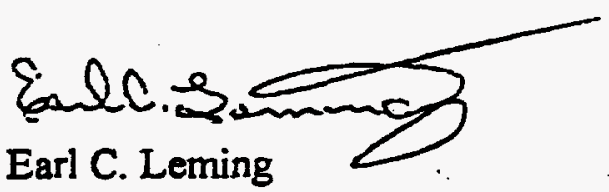

Director

cc: Dodd Galbreath, Tennessee Environmental Policy Office

Mike Mobley, Division of Radiological Health

Susan Gawarecki, Oak Ridge Reservation Local Oversight Committee

Mary Bryan, Oak Ridge Site Specific Advisary Board

James C. Hall, Manager DOE ORO 
Tennessee Department of Environment and Conservation/DOE Oversight Division

Comments on Draft Environmental Assessment

DOE/EA-1210, June 1997,

Lead Test Assembly Irradiation and Analysis Watts Bar Nuclear Plant, Tennessee and Hanford Site, Richland, Washington

\section{GENERAL COMMENTS}

- It should be clearly stated that the same design, configuration, and number of tritiumproducing burnable absorber rod lead test assemblies (TPBAR-LTAs) will be used during tritium testing as would be used during regular production or the differences explained.

- All wastes generated, including but not limited to radionuclides, should be identified.

It is exhilarating to see the Department of Energy identify a very practical and "common sense" solution to a complex problem. The initial ideas to construct a completely new reactor or an accelerator to produce tritium for defense purposes seemed conceptually weak from a technological, political, environmental, and public opinion perspective. This proposed approach incorporates existing materials and assets and allows an engineered solution to the problem of tritium production for both national defense and industrial applications.

\section{SPECIFIC COMMENTS}

Page 1-1, last paragraph.

"A combination of the Commercial Light Water Reactor (CLWR) and accelerator alternatives (one option to serve as the primary tritium source with the other serving as the backup source) was selected in the Tritium Supply and Recycling Programmatic Environmental Impact Statement (TSR PEIS) Record of Decision (60 FR 63877-63891)."

DOE seems to be determined to include an accelerator as at least a secondary or backup tritium source. To be a practical backup, the accelerator must exist. If, one does not exist one can only assume one will be built and available as a backup. Tennessee's original comments (May 12, 1995, letter to Stephen M. Sohinki, US DOE) had assumed that if, a Light Water Reactor (LWR) was used, an accelerator would not be built at environmental and taxpayer expense. Simply select different LWRs (within the TVA system, if necessary) as secondaries in case of unexpected outages at the primary.

\section{Section 2.2.2. Page 2-4}

Would irradiation of the lithium produce increased pressures within the TPBAR-LTA assembly as lithium was converted to tritium? If so, would that pressure increase be negligible? 


\section{Section 2.2.3. Page 2-4}

What types and activities of neutron activated materials will be produced within the TPBAR-LTA during and after irradiation? Please list the individual isotopes and activities that would be expected.

\section{Section 2.2.4, Page 2-4}

Does the Oak Ridge Reservation have a neutron radiography facility that would be suitable for the post irradiation examination? Would Oak Ridge be an interim stop for TPBAR materials bound for Hanford?

\section{Page 2-3. paragraph 3}

What have previously mentioned DOE tests shown about the potential of TPBARs cladding to fail and cause large leaks, such as into the reactor pool and primary coolant? Are the same manufacturing quality control checks done as for typical burnable borosilicate absorber rods, control rods, and fuel rods which are typically manufactured in the private sector? Is the frequency of cladding failure similar? What are the specific differences in cladding construction and materials, if any?

\section{Page 2-5, paragraph 2}

"All of the TPBARs may then be punctured to collect and analyze gases that accumulated during irradiation, and the penetrations would be resealed prior to storage or further handling."

What have, mentioned, previous DOE tests shown about gas characteristics in the TPBARs and pressure differentials between internal and external zones? Have tests already been done under similar neutron fluxes and bums? This information would be valuable in order to evaluate hazards before the TPBARs are irradiated and shipped to Hanford: The State of Tennessee is responsible for emergency management for the Watts Bar Nuclear Plant (WBN) vicinity and requests the information for emergency preparedness.

\section{Pages 5-1, 5-3, D-18, \& D-19}

"Erickson et al 1997" is referenced in section 5.1.1.2 on page 5-1, section 5.2 on page 53 and in section 5.4.2 on page 5-5; however, that reference is not included in the list of references on pages D-18 \& D-19.

\section{Section D-1. Page D-1}

Are the radionuclide levels identified in Table D-1 representative of the levels expected after irradiation or are they theorized maximums? 

Mr. Earl C. Leming, Director

DOE Oversight Division

Department of Environment and Conservation

761 Emory Valley Road

Oak Ridge, Tennessee 37830-7072

Dear Mr. Leming:

RESPONSE TO COMMENTS ON DRAFT ENVIRONMENTAL ASSESSMENT DOE/EA-1210: LEAD TEST ASSEMBLY IRRADIATION AND ANALYSIS, WATTS BAR NUCLEAR PLANT, TENNESSEE AND HANFORD SITE, RICHLAND WASHINGTON

The Richland Operations Office has received your comments, dated June 27. 1997. on the subject draft Environmental Assessment (EA). Thank you for your interest in the environmental impacts of this project and for your comments. Responses to the comments are enclosed.

If you have any questions please contact Julie Turner. NEPA Document Manager. on (509) $372-4015$ or myself on (509) 376-6667.

\section{Sincerely,}

STP:JKT

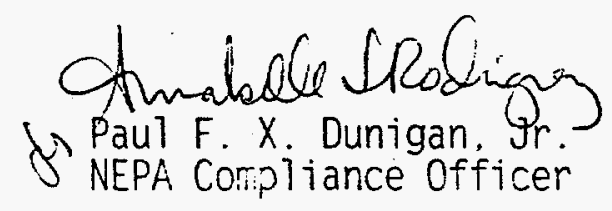

Enclosure

CC W/encl:

C. M. Borgstrom, EH-42

S. M. Sohinki. DP-62 


\author{
DEPARTMENT OF ENERGY \\ RICHLAND OPERATIONS OFFICE \\ RESPONSES TO COMMENTS FROM \\ STATE OF TENNESSEE, DEPARTMENT OF ENVIRONMENT AND CONSERVATION \\ ON THE DRAFT ENVIRONMENTAL ASSESSMENT \\ LEAD TEST ASSEMBLY IRRADIATION AND ANALYSIS
}

General Comments:

It should be stated that the same design, configuration and number of TPBARS used during the test wi 77 be used during regular production.

It is not necessarily true that the same number. design or configuration of TPBARs used for the LTA test would also be used during regular production. The results from the LTA test, along with the design of the reactor eventually selected for production and the quantity of tritium required, will determine the eventual production configuration.

\title{
A17 waste generated. should be identified.
}

Sections 2.2 .5 and 5.3 of the EA identify, both qualitatively and quantitatively, the expected types and volumes of waste generated during each phase of the proposed action. Wastes generated by routine operations at the reactor, which would not be impacted by the proposed action, were not specifically called out but are discussed in NRC (1995).

Specific Comments:

1. Section 2.2.2. Page 2-4 - Would irradiation of the 7ithium produce increased pressures within the TPBAR-LTA assembly as the lithium was converted to tritium? If so, would that pressure increase be negligible?

Generation of tritium and helium during irradiation would increase the pressure within the TPBARs. However, they are designed to maintain their integrity under conditions expected during shipping, handling, and reactor Condition I - IV events, with the exception of a (Targe break loss of coolant accident). An evaluation of expected performance of the TPBARs under the conditions at the Watts Bar Nuclear Plant (WBN) is described in a separate report (Erickson et a) 1997). The TPBAR maximum internal design pressure is 3000 psia and the external design pressure is 2500 psia. The actual internal pressures in the TPBARs during and after the irradiation cycle are anticipated to be much lower than the design criteria (14.7 to 1755 psia).

2. Section 2.2.3. Page 2-4 - What types and activities of neutron activated materials wi 77 be produced within the TPBAR-LTA during and after irradiation? please 7ist the individual isotopes and activities that would be expected.

The TPBAR radionuclide inventory at various times after completion of the irradiation cycle was evaluated in a separate document (TTQP-1-050). 
Based on that assessment, bounding inventories in the TPBARs and LTA hardware were assumed for purposes of the analysis in the environmental assessment $(E A)$. The bounding TPBAR and hardware radionuclide inventories are summarized in Appendix D. Table D.1 of the EA.

3. Section 2.2.4. Page 2-4 - Does the Oak Ridge Reservation have a neutron radiography facility that would be suitable for the post irradiation

examination? Would Oak Ridge be an interim stop for TPBAR materials bound for Hanford?

It is our understanding that the neutron radiography facility at ANL-W is the only operational DOE facility capable of handling the TPBARs. Use of facilities at ORR for this activity is unlikely for the reasons described in Section 3.2 of the EA; therefore. ORR would not be a potential stop during transport of the TPBARs from WBN to Hanford.

4. Page 2-3, paragraph 3 - What have previously mentioned DOE tests shown about the potential of TPBARs cladding to fail and cause large leaks. such as into the reactor pool and primary coolant? Are the same manufacturing quality control checks done as for typical burnable borosilicate absorber rods. control rods, and fuel rods which are typically manufactured in the private sector? What are the specific differences in cladding construction and materia7s, if any?

Erickson et al (1997) describes the results of previous DOE tests as related to the expected safety and operational performance of the TPBARs at WBN. The potential for, and consequences of, a TPBAR failure are described in Erickson et al (1997) and in section 5.4.2 of the EA. Such an event would result in a smal1 (less than $2 \%$ ) increase in the offsite consequences compared to those from WBN routine operations, and would not cause the facility. to exceed any regulatory standards.

The TPBARs are designed and manufactured to the same safety and quality standards as the commercially produced Westinghouse PWR burnable absorber rods. A quality assurance audit of the process used to manufacture the TPBARs was conducted to ensure that NRC nuclear safety requirements were being implemented. Substitution of TPBARs for a small number of the standard absorber rods is not expected to affect performance of the reactor or its safety systems under normal or off-normal operating conditions (see also response to specific comment \#1). More detailed descriptions of the TPBAR design are provided in Erickson et al (1997) and in TTQP-1-015, which is included as Appendix A to the EA.

5. Page 2-5, paragraph 2 - What have, mentioned, previous DOE tests shown about gas characteristics in the TPBARs and pressure differentials between internal and external zones? Have tests already been done under similar neutron fluxes and burns? This information would be valuable in order to evaluate hazards before the TPBARs are irradiated and shipped to Hanford. The State of Tennessee is responsible for emergency management for the Watts Bar Nuclear Plant (WBN) vicinity and requests the information for emergency preparedness. 
The expected performance of the TPBARs under operating conditions at WBN are described in Erickson et a7 (1997), based on previous tests at DOE facilities: (see also response to specific comment \#1 regarding the expected pressure within the TPBARS). No potential effects on WBN plant or safety system operation were identified, and tritium that might be released from the TPBARs under off-normal conditions would contribute only minimally to the consequences of accidents evaluated in the WBN FSAR. Detailed performance data for tritium retention in the TPBAR components are classified: however, a bounding estimate of the tritium release and consequences from a severe transportation accident are described in the EA, sections 5.5.2.1 and D.4.2.

6. Pages 5-1, 5-3, D-18, and D-19 - "Erickson et a7 1997" is referenced in section 5.1.1.2 on page 5-1. section 5.2 on page 5-3. and in section 5.4.2 on page 5-5: however, that reference is not included in the list of references on pages $D-18$ and $D-19$.

The reference is listed in section 8.0, page 8-1, which is the reference list for the main text of the EA. Pages D-18 and D-19 contain only the references for Appendix D. in which the Erickson document was not cited.

7. Section D-1, page D-1 - Are the radionuclide leve7s identified in Table D1 representative of the levels expected after irradiation or are they theorized maximums?

The radionuclide inventories in Table 0.1 represent the bounding design inventories for the TPBARs following irradiation (see section D.1. paragraph 2, and TTQP-1-050). The best estimate inventories are similar to the bounding estimates for most radionuclides: however, for a few isotopes they may be up to $60 \%$ lower than the bounding design inventories.

\section{References:}

Erickson, LW, A. Lopez, E.F. Love, B.E. Schmitt. E.R. Gilbert, R.L. Van Witbeck. 1997. Report on the Evaluation of the Tritium Producing Burnab7e Absorber Rod Lead Test Assemb7y. PNNL-11419, Rev. 1. Pacific Northwest National Laboratory, Richland, Washington.

U.S. Nuclear Regulatory Commission (NRC). 1995. Final Environmental Statement Related to the Operation of Watts Bar Nuclear Plant. Units 1 and 2. NUREG-0498. Office of Nuclear Reactor Regulation. U.S. Nuclear Regulatory Commission. Washington. D.C.

Tritium Target Qualification Project (TTQP). 1996. Description of the Tritium-producing Burnable Absorber Rod for the CLWR Lead Test Assemb7y. TTQP-1-015. Prepared by Mohr and Associates. Richland. Washington for Pacific Northwest National Laboratory. Richland, Washington. 



\title{
FINDING OF NO SIGNIFICANT IMPACT
}

\author{
LEAD TEST ASSEMBLY \\ IRRADIATION AND ANALYSIS \\ WATTS BAR NUCLEAR PLANT, \\ TENNESSEE AND \\ HANFORD SITE, \\ RICHLAND, WASHINGTON
}

\author{
U. S. DEPARTMENT OF ENERGY \\ RICHLAND OPERATIONS OFFICE \\ COOPERATING AGENCY: \\ TENNESSEE VALLEY AUTHORITY
}

July 1997 



\section{FINDING OF NO SIGNIFICANT IMPACT}

AGENCY: U.S. Department of Energy

COOPERATING AGENCY: Tennessee Valley Authority

ACTION: $\quad$ Finding of No Significant Impact

SUMMARY: An environmental assessment (EA) has been prepared to assess potential environmental impacts associated with a U.S. Department of Energy (DOE) Proposed Action to conduct a lead test assembly (LTA) program to confirm the viability of using a commercial light water reactor (CLWR) to produce tritium. The Proposed Action described in the EA supports DOE's Record of Decision for the Programmatic Environmental Impact Statement for Tritium Supply and Recycling (TSR PEIS). The EA tiers from the TSR PEIS and covers only those activities necessary to conduct tests involving irradiation of tritium-producing burnable absorber rods (TPBARs) in a CLWR and post-irradiation examination (PIE) of the TPBARs. The Proposed Action would involve preparation and analysis activities at DOE facilities and irradiation of the TPBARs at a commercial nuclear power reactor. Based on the analysis in the EA and considering concerns expressed by the Yakima Indian Nation, and comments received from the states of Tennessee and Washington, DOE has determined that the Proposed Action is not a major federal action significantly affecting the quality of the human environment within the meaning of the National Environmental Policy Act of 1969 (NEPA). Therefore the preparation of an environmental. impact statement is not required.

\section{ADDRESSES AND FURTHER INFORMATION:}

Single copies of the EA and further information concerning the proposed action are available from

Debbie Trader, Director

Science and Technology Programs

U.S. Department of Energy

Richland Operations Office

Richland, Washington 99352

(509) $372-4015$

For further information regarding the DOE NEPA Process, contact:

Carol Borgstrom, Director

Office of NEPA Policy and Assistance (EH-42),

U.S. Department of Energy,

1000 Independence Avenue, S.W.,

Washington, D.C. 20585

(202) 586-4600, or (800) 472-2756.

PURPOSE AND NEED: The U.S. Department of Energy (DOE) needs to confirm the viability of using a commercial light water reactor (CLWR) as a potential source for maintaining the nation's supply of 
tritium. The Proposed Action discussed in this environmental assessment is a limited scale confirmatory test that would provide DOE with information needed to assess that option.

\section{BACKGROUND: DOE's Programmatic Environmental Impact Statement for Tritium Supply and Recycling (TSR PEIS), described the need for a new source of tritium for defense purposes as summarized in the following.}

Since nuclear weapons were developed in 1945, a nuclear deterrent has been a cornerstone of the nation's defense policy and national security. Tritium is used to enhance the yield of current nuclear weapons and allows for the production of smaller or more powerful devices. The United States has based its strategic nuclear systems on designs that use tritium and therefore requires a reliable source of this material in order to maintain the nuclear weapons stockpile as required by law.

Tritium has a relatively short radioactive half-life of 12.3 years. Because of this relatively rapid radioactive decay, tritium must be replenished periodically in nuclear weapons to ensure that they will function as designed. Over the past 40 years, DOE has built and operated 14 reactors to produce tritium and other nuclear materials for weapons purposes. Today, none of these reactors is operational, and no tritium has been produced since 1988.

Until a new source of tritium is operational, DOE will continue to meet tritium requirements by recycling tritium from existing weapons as they are retired from the weapons stockpile. However, because tritium decays relatively rapidly, recycling can only meet tritium demands for a limited time. Current predictions of future stockpile scenarios indicate that recycled tritium will adequately support the nation's nuclear stockpile until approximately 2005 . (At the time the TSR PEIS was published, a previous assessment of the need for new tritium had placed that date at 2011; the current target date of 2005 is based on a more recent analysis). The tritium supply and recycling facilities as proposed in the TSR PEIS would provide the capability to produce tritium safely and reliably in order to meet the nation's defense requirements well into the 21 st century while also complying with environmental, safety, and health standards.

In the TSR PEIS, DOE proposed several alternatives to provide a new source of tritium for the nuclear weapons program (DOE 1995a). The TSR PEIS evaluated alternatives for the siting, construction, and operation of tritium supply technology and recycling facilities at each of five candidate sites: the Idaho National Engineering and Environmental Laboratory (INEEL) in Idaho, the Nevada Test Site (NTS) in Nevada, the Oak Ridge Reservation (ORR) in Tennessee, the Pantex Plant in Texas, and the Savannah River Site (SRS) in South Carolina.

The TSR PEIS included an analysis of the use of a light water reactor (LWR) as well as the use of an accelerator for production of tritium. As part of the LWR alternative, DOE considered the purchase of an operating or partially completed commercial power reactor, or purchasing irradiation services from an existing CLWR. A combination of the CLWR and accelerator alternatives (one option to serve as the primary tritium source with the other serving as the backup source) was selected in the TSR PEIS Record of Decision (60 FR 63877-63891). A decision is expected by the end of 1998 to determine which option will be the primary source for tritium and which will serve as the backup source. 
This EA tiers from the TSR PEIS and covers only those activities that would be necessary to conduct tests involving irradiation of tritium-producing burnable absorber rods (TPBARs) in a CLWR and postirradiation examination (PIE) of the TPBARs. Aspects of the actual tritium production program or operations at the CLWR used to irradiate the TPBARs are, or would be, addressed by separate NEPA documentation. The commercial reactor proposed to perform the irradiation in this EA may or may not be the reactor selected for actual tritium production in the future. If the CLWR alternative is selected to be a primary or backup tritium source, the selection of the specific reactor(s) eventually used for the production mission would be addressed by a separate site-specific NEPA analysis.

PROPOSED ACTION: The Proposed Action would confirm the results of developmental testing conducted previously at DOE facilities and provide DOE with information regarding the actual performance of the TPBARs in a CLWR. It would also demonstrate that tritium production could be carried out within the normal operating and regulatory constraints associated with a commercial nuclear power facility, without affecting the plant's safety systems, production capacity, or normal operations. These activities would provide added confidence to the utilities and the NRC, which regulates commercial power reactors, that tritium production in a CLWR could meet national security needs in a technically straightforward, safe and cost effective manner.

Activities associated with the Proposed Action include replacing four conventional PWR burnable absorber assemblies with assemblies containing the TPBARs (referred to as TPBAR-LTAs) during the next refueling outage at the Watts Bar Nuclear plant (WBN), Unit 1 in southeastern Tennessee. The TPBARs would be shipped from the Hanford Site near Richland, Washington to the Westinghouse fuel fabrication facility in Columbia, South Carolina, for assembly into TPBAR-LTAs. The TPBAR-LTAs would be inserted into four new fuel assemblies at Westinghouse. The fuel assemblies with the TPBARLTAs (hereafter referred to as "integrated assemblies") would then be shipped to WBN with the rest of the new fuel and stored until the next refueling outage, when they would be inserted into the reactor. $A$ typical fuel reload would contain more than 1000 burnable absorber rods, of which 32 would be replaced by the TPBARs in the proposed test.

The TPBAR-LTAs would be irradiated for one complete operating cycle (approximately 18 months), following which they would be removed from the integrated assemblies and stored in the spent fuel pool. The fuel assemblies would be placed back in the reactor as part of the refueling process. The TPBARLTAs would be shipped to the Pacific Northwest National Laboratory (PNNL) at Hanford for postirradiation examination (PIE). Because the fuel assemblies from the integrated assemblies could be returned to the reactor core during refueling, no shipment or disposal of spent nuclear fuel would be required as part of the Proposed Action.

As part of the PIE activities at Hanford, the TPBARs would be removed from the remaining hardware. The TPBARs would then be subjected to non-destructive evaluation (NDE), including a visual inspection and gamma radiography. The TPBARs would also be punctured to collect and analyze any gases that accumulate during irradiation, and the penetrations would be sealed before the TPBARs are stored or processed further.

The TPBARs may also be examined by neutron radiography at the Argonne National Laboratory-West (ANL-W) near Idaho Falls, Idaho. Upon completion of the neutron radiography, the TPBARs would be returned to PNNL for destructive examination. For this evaluation, laboratory wastes that result from the destructive examinations, intact spent TPBARs, and residual equipment and materials that remain from 
cleaning out the facilities are assumed to be dispositioned as waste at the Hanford Site. The small quantities of radioactive waste that may be generated at other locations would be disposed with similar wastes from those facilities.

ALTERNATIVES CONSIDERED: The EA discussed several alternatives to the proposed action as well as the No Action Alternative.

No Action: Under a no-action alternative, DOE would not conduct the LTA program or post-irradiation examinations. The final selection of either a CLWR or an accelerator as the nation's primary tritium source would be made without the benefit of the results of this proposed project. The no-action alternative is not consistent with the Department's purpose and need and therefore was not considered reasonable. However, evaluation of the No Action alternative is required by NEPA as a baseline against which to assess the impacts of the Proposed Action and alternatives.

Irradiation at Other Reactor/Analysis at Other DOE Laboratory: DOE considered the use of another commercial reactor to conduct the LTA program, as well as the use of other DOE laboratory facilities for examining the TPBARs. WBN was proposed for these tests because its refueling schedule provided optimum timing for obtaining the performance data needed by DOE, and because it was the only reactor of compatible design that was not encumbered by vendor restrictions on use of its fuel or other components for defense-related research. All other U.S. PWRs of this design obtain their fuel from foreign vendors that impose contractual restrictions on use of their products for defense-related purposes. Use of any facility other than WBN would have required DOE to replace all of the reactor's fuel, resulting in possible delay of the tests as well as substantially increased cost. Therefore, DOE considered options other than use of WBN to be unreasonable for the proposed tests. A future, separate evaluation process would identify one or more facilities for the actual tritium production mission. Reactors owned by DOE (such as the Fast Flux Test Facility [FFTF] at Hanford or the Advanced Test Reactor at the INEEL) or reactors operated by universities were not considered reasonable alternatives because they do not meet the purpose of, and need for, the Proposed Action, which is to demonstrate the viability of producing tritium in a CLWR.

Other DOE laboratories could perform the post-irradiation activities if the technology were transferred to those laboratories, and if the laboratories possessed hot cells large enough to contain the full length of the TPBAR-LTAs. This alternative was not considered reasonable because Hanford has the technology for post-irradiation examination of the TPBARs. Further, Hanford has hot cells suited for this purpose and has conducted similar types of examinations in the past. Use of alternate facilities would introduce technical uncertainties and impact both the schedule and cost for the proposed tests; therefore, this alternative was not evaluated in detail.

Analysis at Private Facility: DOE also considered the use of a private hot cell facility to conduct the analysis on the irradiated TPBARs. However, hot cells with the ability to handle the quantities of radioactive materials involved and to accommodate the full-length assemblies are generally not available outside the DOE complex. The exception would be a commercial nuclear fuel fabrication facility which is owned by a foreign corporation. However, the security measures required to perform the work in a foreign-owned facility would be difficult to implement. For these reasons, use of non-DOE facilities was not considered reasonable and is not evaluated further.

ENVIRONMENTAL IMPACTS: The environmental consequences of the proposed action would be well within existing state and federal standards, and are not expected to result in any appreciable risks to 
members of the public, workers, or the environment. The major impacts are summarized in the following section; other types of consequences were determined to be negligible and are not discussed in detail.

Air Quality - Radionuclide emissions to the atmosphere could occur during destructive examination of the TPBARs at Hanford. An upper bound estimate of the air emissions would result in a dose to an offsite member of the public that is less than $3 \%$ of the EPA and Washington State standards. The risk of latent cancer fatality (LCF) from those emissions would be less than 1 in 5 million for the maximally exposed individual, and less than 1 in 1400 for the offsite population within 50 miles $(80 \mathrm{~km})$ of the site. The risks from radionuclide air emissions would not increase at other locations participating in the proposed activities. In addition, emissions of regulated nonradiological materials to air are not expected to increase above current levels and would remain within applicable regulatory standards.

Water Quality - Routine emissions of radioactive or hazardous materials to groundwater or surface waters are not anticipated for any activity in the proposed action other than irradiation of the TPBARs at WBN. Small quantities of tritium that may be released from the TPBARs during irradiation would not increase the risk associated with WBN by comparison to the facility's normal operations.

Waste Management - Destructive examination of TPBARs at Hanford would generate less than $25 \mathrm{~m}^{3}$ of solid low level radioactive waste (LLW), and less than $0.5 \mathrm{~m}^{3}$ of LLW at other facilities. Decontamination of the facility and disposal of equipment used for PIE could generate an additional $200 \mathrm{~m}^{3}$ of LLW at an undetermined time in the future; however, the facilities and equipment would likely be retained and used for other research in addition to the proposed action. The proposed action would also result in the generation of small quantities of mixed waste and hazardous materials (e.g., solvents). All radioactive and hazardous materials would be managed and reused, recycled, or disposed of in accordance with applicable federal and state regulations. The volumes of waste generated by the proposed action are not anticipated to impact overall waste management activities at any of the participating facilities. Because of the relatively short-lived radionuclides that would be generated by the proposed actions, no long-term effects on groundwater are expected.

Transportation - The radiological consequences of incident-free transportation to members of the public were estimated as less than 3.4 person-rem, resulting in LCF risks of less than 1 in 500 to the entire population along the transportation routes. The radiological consequences for transport crews amounted to 0.9 person-rem, resulting in a collective LCF risk of 1 in 2500. The collective radiological risks from transportation accidents amounted to 1 in 3000 for members of the public. The nonradiological risks for transportation fatalities were about 1 in 25,000 from vehicle emissions and less than 1 in 1500 from traffic accidents.

Facility Accidents - A variety of accidents were evaluated for activities in the proposed action, ranging from low consequence, higher probability events to high consequence incredible events. The doses from accidental radiological releases at facilities participating in the proposed action amounted to less than 14 rem for an onsite non-involved worker and $1.6 \mathrm{rem}$ for a member of the public. The maximum LCF risk for the accidents evaluated was 1 in 10,000 for an onsite individual and 1 in 100,000 for a member of the public. All of the hypothetical events fell within accepted safety guidelines for DOE facilities.

Health and Safety - The collective dose to workers during the proposed actions was estimated to be less than 3 person-rem, resulting in a LCF risk of about 1 in 800 . Non-radiological industrial hazards are expected to result in at most one recordable event (injury or illness) over the course of the proposed action. 
Other Environmental Impacts - The consequences of the proposed action are expected to be negligible for other types of impacts, including those on land use, socioeconomics, cultural resources, aesthetic or scenic resources, geologic resources, ecological resources, noise, or site services. A Biological Resource Review supports these expectations.

Cumulative Impacts - The proposed action is not expected to contribute substantially to the overall cumulative impacts from past or anticipated operations at WBN, ANL-W and HFEF, or on the Hanford Site.

Environmental Justice - Executive Order 12898, Federal Actions to Address Environmental Justice in Minority Populations and Low-Income Populations, requires that Federal agencies identify and address, as appropriate, disproportionately high and adverse human health or environmental effects of their programs and activities on minority and low-income populations. Because no adverse effects are anticipated as a result of the proposed actions, there would be no opportunity for disproportionately high and adverse consequences to minority, or low-income populations.

DETERMINATION: Based on the analysis in the EA, and after considering the preapproval review comments of the State of Tennessee, the State of Washington and concerns of the Yakama Indian Nation, I conclude that the proposed action, modified to include the administrative control measures recommended by the panel, does not constitute a major federal action significantly affecting the quality of the human environment within the meaning of NEPA. Therefore, an EIS for the proposed action is not required.

Issued at Richland, Washington, this $\angle Q N$ day of July 1997.

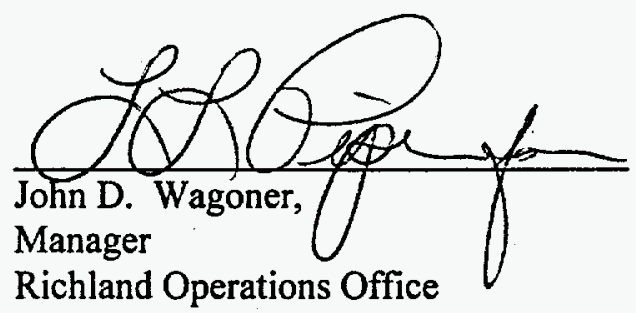

